\title{
Lapurdum
}

Euskal ikerketen aldizkaria | Revue d'études basques |

Revista de estudios vascos | Basque studies review

6 | 2001

Numéro VI

\section{Epaiketa eta Endogamia Nafarroako Margaritaren Le Miroir de l'âme pécheresse-n [Arima Bekatariaren Mirailan]}

Koldo J. Garai

\section{CpenEdition}

Journals

Édition électronique

URL : http://journals.openedition.org/lapurdum/1201

DOI : 10.4000/lapurdum.1201

ISSN : 1965-0655

Éditeur

IKER

Édition imprimée

Date de publication : 1 octobre 2001

Pagination : 119-193

ISBN : 2-84127-156-0

ISSN : $1273-3830$

Référence électronique

Koldo J. Garai, « Epaiketa eta Endogamia Nafarroako Margaritaren Le Miroir de l'âme pécheresse-n [Arima Bekatariaren Mirailan] », Lapurdum [Linean], 6 | 2001, Sarean emana----an 01 juin 2009,

kontsultatu 31 janvier 2020. URL : http://journals.openedition.org/lapurdum/1201 ; DOI : 10.4000/ lapurdum. 1201 


\section{Koldo J. Garai}

English DepartmentUniversity of Maryland eta

Hizkuntza eta Literaturaren Didaktika Euskal Herriko Unibertsitatea

koldo@wam.umd. edu

tlpgabik@vc. ehu. es

ezponda@hotmail.com

\section{Epaiketa eta Endogamia Nafarroako Margaritaren Le Miroir de l'âme pécheresse-n [Arima Bekatariaren Mirailan]*}

To Jane Donawerth and Jeanne Fahnestock, thanks.

\section{Sarrera}

\subsection{Artikuluaren alderdi zabalak}

Gurako nioke nire lanari abia eman berez duen itzala baino esparru zabalagoan kokatuz eta holan iradokiz inoizkorako asko interesatzen zaizkidan zenbait ikerlerro; hots ikerlerrook ez dira artikuluan bertan landuko baina.

\footnotetext{
"Testu honen aurretiko ahozko bertsio ingelesa Rhetwric Society of Americako bederatzigarren bitutekariko kongresu nazionalean irakurti nuen. Kongresu horrek, 2.000ko Maiatzaren 28an Washingtonen antolatu zena, "Professing Rhetoric" "Erretorika Irakatsiz" zeukan izena. Horren aurretik, ingelesezko aurreko bertsio idatzia Jane Donawerth doktorearen Errenazimenduko idazle emakumeen gaineko mintegirako prestatu nuen, mintegi hori 1999ko Ekainean antolatu zen College Parkeko Marylandeko Unibertsitateko Ingeles departamenduan. Berari nire eskerrik minenak. Gajoak testu honen aldaki guztiak irentsi behar izan ditu; kontutan izanik unibertsitate espainolek ez dutela erretorika praktikorik irakasten, hots, ez dutela onuragarritzat hartzen artikuluak idazten irakastea (eta ez nabil bibliografia konbentzioez), andre doktore dotore horrek egin behar izan duen lana ez da hutsaren hurrengoa izan : hala ere, noski, artikuluak huts egin dezanean esanonekoa izan ez naizelako izan daiteke. Antzeko egoeran egon izan dira nite bidaide eta hauspo emaile diren Ana I. Morales eta Ricardo Etxepare, baina gainera Ana I. Moralesek itzuli egin ditu ingelesetik euskarara ia-ia aipu guztiak musu truke (inoiz ez hobeto esana), beraz, literatura ona gure itzultzailerik onenetakoak emana dastatzeko aukera izango dugu artikuluan. Azkenik (baina ez gutxienik), eskertu gura nuke Aurelia Arkotxa, lana erabat zokoratuta zegoenean, ingelesez irakurri eta. euskeraz emateko beta eta moien eman didalaka.
} 
esparrua definitzen langa lanak egingo dituzte. Ikerlerro horiek hurrengo kontzeptuen arteko hartu emana dute lan-hazitzat: ahozkotasunaren eta idatzizkotasunaren arteko harremanak. Horren harian susmo batek narabil hausnar azken aspaldi honetan eta hauxe da: hamaseigarren mendeko Europa kontinentalak ez ote zuen "ahozkotasuna" maila askotatik ezabatu nahi izan. Argi dago honegaz guztiaz ahozkotasuna literaturari baino zerbait sakonagoari lotzen ari natzaiola, edota, literatura gure ingurune akademikoan ulertu ohi den kontzeptu txiro, kanoniko eta handigura hori baino gauza sakonagoa eta errotikoagoa dugula. ${ }^{1}$

Orain goazen mailarik maila ikusten zer esan gura dudan "ahozkotasuna" ideiarekin. Adibidez maila politikoan, estatu berri isomorfoek nazio ahulagoak eta tarteko lurraldeak antolatzen zituzten unitate geopolitiko eta judizialak kendu egin zituzten, Nafarroako erresumak pairatu zuen bezala. "Ahozkotasuna" esan diodana berdindu liteke Inperioak ahalbidetzen zuen heterogeneitate Machiaveliarrarekin, hots, lekuan lekuko itunak agintzeare$\mathrm{kin}$, mendetasun maila diferentedun erresuma txiki eta bestelako antolakuntza geopolitikoei bidea eginez. Heterogeneitatea ahozkotasunari lotzen zaio eta isomorfismoa idatzizkotasunari.

Maila judizialean, dedukziozko definizio geopolitiko berri honek ezabatuko zi uen tokian tokiko parlamentuetako lege, ohitura eta foru guzti, identitate eta partikulartasunak ezabatuz, goitik behera emanda zetorren orokortasunaren alde.2 Dedukzioa idatzizkoari lotzen diot, eta indukzioa ahozkotasunari, Adrian Celayari jarraituz; esaterako Euskal Foruak induktiboak lirateke tipikoki. ${ }^{3}$ Era honetara, alde batean heterogeneitatea, partikulartasuna eta indukzioa ahozkotasunarekin lerratzen ari naiz, eta, bestean, isomorfismoa, orokortasuna eta dedukzioa idatzizkotasunarekin. Erlazio hauek berez, gehiagorik gabe, ez dira zertan onartu, maila espekulatiboari baitagozkio, baina intuitiboki zuzenak dirudite.

Apur bat aurrerago azartuko naiz eta irudikapen mailari edo maila sinbolikoari eutsiko diot - hots, kultur ekoizpenetan gizartearen kontzeptualizazioak nola ageri diren ispilaturik - eta proposatuko dut irudia ahozkotasunarekin lerra daitekeela eta itzulpena idatzizkotasunarekin. Esan dezagun hamaseigarren mendean hipotesizatzen ari naizen ahozkotasunaren kontrako erasoa intelektualek eta erreformistek eratu zuten mugimendu ikonoklastan gauzatu zela. Berbarako, Erasmusen Copia (Ugaritasunaz) hizkuntza idatziaren nahikotasunaren goraipatze bezala irakur dezakegu, katolikoek erabili ohi zuten irudien bidezko indoktrinazio sinbolikoaren kontra. Irudia, eta areago sinbolotzat hartu beharreko irudia, hitzetara ekartzen erraza ez izan arren, 
horrek ez dio kontaketarako ahalmenik kentzen, narratibogarritasunik kentzen, Mieke Balek ondo ageri duenez. ${ }^{4}$ Beraz, irudien kontrako mugimenduak arrazoimena erretorikaren bidez gidatuko dela suposatzen du, bai alde heuristikoan bai alde hermeneutikoan. Hori horrela izango bada, hots. hitzak irudia ordezkatuko badu, beste eskakizun soziokulturalik ere gauzatt. beharko da: biztanleriaren parte handi batek alfabetaturik behar du egon eta, gainera, testu idatziak eskura egon behar dira larguro. Hain zuzen horixe zen erreformisten eskakizunetako bat, Bibliara bitarteko hermeneuta edo eklesiastiko barik heltzeko eskubidea, eta testuaren lehentasuna liturgia eta sakramentuen gainetik; bi sozio-kultur eskakizunok ezinezkoak izango ziratekeen ez balitz XIV mendetik zetorren informazioaren demokratizazioagatik burgesak unibertsitateetara sartzen hasi zirenekoa-, eta ildo beretik, inprentagatik. Hemendik dator ba biztanleria alfabetatzeko grina hori.5 Noan orain artikulu honen funtsezko hipotesia aipatzera.

\subsection{Azterbideak eta azterburuak}

Artikulu honetan Nafarroako Margaritaren Le Miroir de l'âme pécheresse: Discord étant en l'homme par contrarieté de l'esprit et de la chair bertsozko obra erlijioso protorreformista aztertuko dut. Obra horretan arimaren eta Jainkoaren arteko erlazioak azaltzen zaizkigu. Testuko narratzailea eta pertsonaia nagusia arima da: rrimak kontatuko dizkigu Jainkoagazkoak, familiaren barruko erlazio gisa formulatuta,

Lan honi heltzean nire ustea zen XVI mendean Europako Mendebaldean aldaketa bat gertatzen ari zela emakumeari leporatu ohi zitzaion rolean, ama roletik emaztearen rolera doan aldaketa, alegia. Roelkerrek (1968) dioskunez, ingurune erreformistan emakumeek plazakontuetan esku hartze zabalagoa izango zuten inguru katolikoan baino, eta. honek eman lezake muturrean bertan gezurtatzen duela proposatzen ari naizen rolen aldaketarekin emakumeek estatusa galdu izana; alabaina Belseyk (1985) dioenez, rolen atontze berri honetan emakumeek luzaroan estatusa galdu arren, aldaketok berok ahalbideratuko zuten garaiko emakume batzuek zerbait askeago jarduteko profitatzeko moduko zirrikiturik eta pitzadurarik asko.

Rolen aldaketa hau eskuz esku letorke esparru politikoan gertatu zen Absolutismoaren ezarpenarekin. Bestela esanda, loturik datorkigu Europako Mendebaldeko herrialde gehienetan XVI mendean suertatu zen beste aldaketa bati, hots, norbanakoaren eta botere egituraren arteko harremanen defi- 
nizio berriari. Izan ere, ikerketa honek erakusten du Europako XVI mendean, ezkontza jaun-basailu edo jaurespen eriaziotzat hartzen zela, eta, horretara, ez zela pentsaezina senar-emazte, aita-alaba, lurjabe-maizter, erregemenpeko eta Jainkoa-arima bikoteak erlazio mota bat eta beraren aldakitzat jotzea.

Jainkoa-arima erlazioa bi halakora izango da metaforikoa maila orokorrenean, bi metafora iurri erabiliko baititu batik bat: a) familia barruko hartu-emanak, eta b) epaiketaren irudia. Azkenengoari dagokionez, esan dezadan testuan badela harako pribatizatze edo etxeratze prozesu bat, arimaren epaiketa plaza-lekuan gertatzetik etxe barruko arazo bilakatuko duena, hots, epaiketa izatetik senar-emazteen arteko erlazioa izatera. Lehengoari dagokionez, bada azpi metafora bat ere: familia patriarkalean erlazio hierarkikoak baino ez du balio, hau da, bakoitzak aita-lehenarekin edo pairiarkarekin dauzkan hartu-emanen araberakoak 6 . Bestela esanda, norbanakoa buruz buru eta banaka definitzen da aitarekiko. Bertikalismo honek azpian duen beste metaforak familia patriarkala bi elementuko giza gorputz bezala ematen digu aditzera, elementu biok burua eta giza gorputzaren beste edozein atal direlarik. Hori esanda, aurrera dezadan nire azterketarako familia patriarkalaren erlazioen esparru metaforikoari eutsiko diodala. Bestalde, sendi erlazioen emakera horiek nire hipotesi nagusian aipatuko ditudan kontzeptu erretorikoen ordezkapenaren testuinguruan ere ikertuko ditut.

Lan honetako hipotesi nagusia hauxe da: Nafarroako Margaritaren Le Miroir de l'âme pécheresse obran, fedea-karitatea kontzeptuek berdintasuna-errukia kontzeptuak ordezkatuko dituzte, egokitasunaren edo adekuazioaren kontzeptua ezabatzearten. Edenen (1997) Ciceroren Topicaren analisiari jarraituz, berdintasuna legea instantzia partikularretara egokitzeko prozesu gisa definituko dut. Gure kasuan hauxe gertatzen da: berdintasuna edo egokitzapena gertatu ordez, berdintze lana egin ordez, goikoak karitate obra bat egingo dio fededunari. Labur eman, errukiaren ordez karitatea izango dugu, eta egokitzapenaren ordez, berriz, fedea. Halan da eze, elkarren buruz buru dauden erlazio funtzioak berdintasuna vs. jaurespena izango direla. Erlazio funtzioen ordezkatze hori familia patriarkalaren esparru metaforikoaren bidez agitzen da. Beherago ikusiko ditugu funtsezko erlazio hauek astiroago.

Azkenik, esan beharra daukat kontzeptu batzuen azterketa erretorikoak oso sendo oratuko diola linguistika kognitiboari. Azken hogei urteotan erretorikako alderdi berri bat sortu da linguistika kognitiboa oinarri hartuta, begiratuz eguneroko hizkuntzan zelan metaforizatzen dugun mundua. Aipatu 
metodoa erabili gurako nuke testuaren azpian datzan sare kontzeptuala argitzeko. Bide nabar, zenbait konparazio egingo ditut katolikoen sare kontzeptualarekin, eta horretarako baliatuko naiz Bernard Etxepareren Linguae Uasconum Primitiae obran bekatu eta bekatari kontzeptuez neuk behinola batean eginiko azterketaz.

\subsection{Testuaren inguru historikoaz}

Testua inportantea da arrazoi zenbaitengatik. Hasteko, testuaren beraren ekoizpenean esku hartu zuten autoreen garrantzia historikoagatik: Nafarroako Margarita egilea izan zen, geroagogarrenean Ingalaterrako Elizabeth Ia izango zena eskuizkribuaren itzultzailea izan zen, Catherine Parr Ingalaterrako Henry VIIIaren orduko emaztea itzulpenaren emendiogilea edo zuzentzailea izan zen, eta Bale jakitunak editatu eta argitaratu zuen A Godly Meditacyon of the Christen Sowle izenburuaren pean bere erbesteratze germaniarrean.

Nire azterketan ardatza izango den edo testu nagusi gisa erabiliko dudan aldakia Elizabethek Gabon Zaharretako opari eman zion Parreri. Garai horietan Gabon Zaharretan opariak egiten ziren, opariok bat etorri behar izaten zutelarik emaileak gizartean hartzen zuen lekuarekin; adibidez, apezpikuei zilarra oparitzea bazegokien ezingo zuten urrezkorik oparitu. Deccoruma zaintzeak edo egoki izate horrek zeukan zailtasuna era honetara areagotzen zen Elizabethen kasuan: Elizabethen ama zendua Ana Boleyn izan zen, adulterioagatik kondenatua eta exekutatua izan zen. Hamaika urteko neskatoa zen Elizabethek oso gaitz, izan zuen Gabon Zaharretan saritzat zer hauta jakitea: alde batetik iturri ofizialek sasikumea zela esaten ziotelako argudioa honetara dator: bere ama adulteroa baldin bazen, erregea ez zen popertza bere aita izango, beste edonor izan zitekeen, eta beraz ez zen printzesa - baina bestetik, bere burua sasikumetzat ez bazuen jotzen, bere aita Erregea zen eta Erregina bere amaordea; alaba gaitzetsia, baina erreginaren alabaordea eta printzesa, hala ere. Beraz, gabonsaria hautatzearekin bere burua definitzen eta ezagunera ematen zebilen.

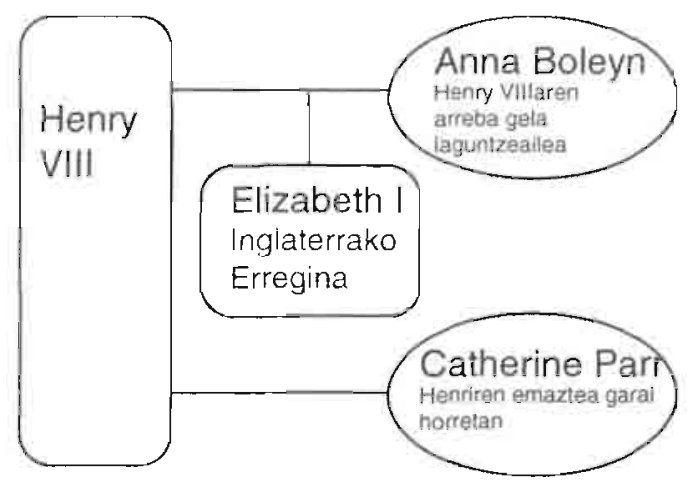


Ingalaterrako egoera ideologiko-politikoaz jardungo dut hurren. Ezagun denez, Henri VIIIa Anglikanismoaren fundatzailea izan zen. Anglikanismoa Katolizismoaren aldakia baitzen, erregea eta bere agindupekoak dendatu ziren doktrina kontuetan Erromatik lar ez urruntzen, eta oso gogor aritu ziren heretikotzat jotzen zen bestelako erreformismoa zapaltzen 7 . Aitzitik, orduko erreginaren gortean, Catherine Parrenean, Erreforma ageriago ala ezkutuago, babesten eta bultzatzen zen. Ingalaterran, areago gabiltzan garaitik aurrerantzean, hiru gorte zeuden, erregearena, erreginarena eta Walesko printzearena, bakoitzak bere botere eta eragin ingurua zuelarik. Hortaz, orduko erreginak ere bere gortea zuen, eta gorte hori erreformista zen, nahiz eta erregearen gortea katoliko anglikanoa izan. Guztiarekin ere, Erreginaren babesa gorabehera, Balek, gure autorearen editoreak erbestera joan behar izan zuen.

Noan azalizera orain zein den Elizabethek testuarekin zeukan harremana. Ana Boleyn, Elizabethen ama, Henri VIIIaren emazte eta, honez, Ingalaterrako erregina izan baino lehen, Henri zortzigarrenaren arrebaren gela laguntzailea edo azafata izan zen, hura Frantziara ezkondu zenean Margaritaren nebarekin, François Frantziako erregearekin alegia. Dirudienez Ana Boleyn eta Margarita lagun minak izan ziren, bi-biok baitzituzten kezka erreformistak. Margaritaren sasoietan, Elizaren ustelkeria eta honen erreformaren beharra hizpide arrunta zen intelektualen artean, beranduagora bilakatuko zen sarraskietarako atxakia. Margaritak testua idatzi zuenean Sorbonak hasieran galazo egin zuen hura argitaratzea, gero baina, Maroten bitartekotzaz, baimendu egin zuten. Litekeena da Margaritak kopia bat Boleyni erregalatu izana, eta halan, urteak aurrera, Elizabethek amaren liburutegian aurkitzea. Emakumezkoek egin ohi zituzten bezuza tipikoak brodatuak izaten ziren: hariaren kalitateak eta erakutsitako "kaligrafiak" ispilatu beharko zuen damaren gizarte maila. Brodatuaren pareko izango zen Elizabethek egingo zuen itzulpena. (Nota bene kritika feministarako, josi-idatzi erlazioa alfabetizazioarekin eta ekoizpen kulturalarekin loturik).

Beraz, Elizabethen Gabonsari hautaketa ezin hobea izan zen, Margaritaren testua protorreformista izanik, Parren gustukoa izango zelako, eta beste aldetik, itzulpena bete-betean sartzen zenez hezkuntza humanistan, Elizabeth esaten zebilelako bera ere bazela gauza erregina izateko, edo behintzat formazioa bazuela jesarleku horretarako. Gainera, bere etxeko liburutegian aurkitutako eskuizkribuaren bitartez Margarita aiputan hartzeagaz, iragan Frantsesa inbokatzen zebilen eta horrekin bere balizko indar politikoa, hain zuzen, Gisatar katoliko fanatikoen kontrakoa izan litekeena, Nafarroa etxean babesa harturik. 8 
Testu honen nabarmentasunerako beste arrazoi bat egileak sortu zueneko baldintza historiko eta biografiakoetatik atera daiteke, batez ere irakurketa feminista egitekotan. Margaritak bere borondatea murriztu eta mozturik zuen alde bitatik: bere neba Frantziako erregea zen, François I Valoisko, eta bere senarra Henri Labriteko, Nafarroako erregea. Margaritaren lekua, esateko, hegi bikoa da, arreba den aldetik bere nebari bidea eman behar diola irakatsi baitzaio, eta emazte den aldetik, bere senarraren "laguntzailea" izaten. Gogoan izan beza irakurleak Nafarroako erresuma, geografia ezabatua zen aldetik, Europako "nazio" berrien eta botere absolutistaren eraketarako argudioen guda-zelaietako nagusienetakoa zela, eta beraz, zein posizio argalean zegoen Margarita (eta, hala ere, zenbatetan ez ote zen bera egon bitartekari nazioarteko arazoetan). 9

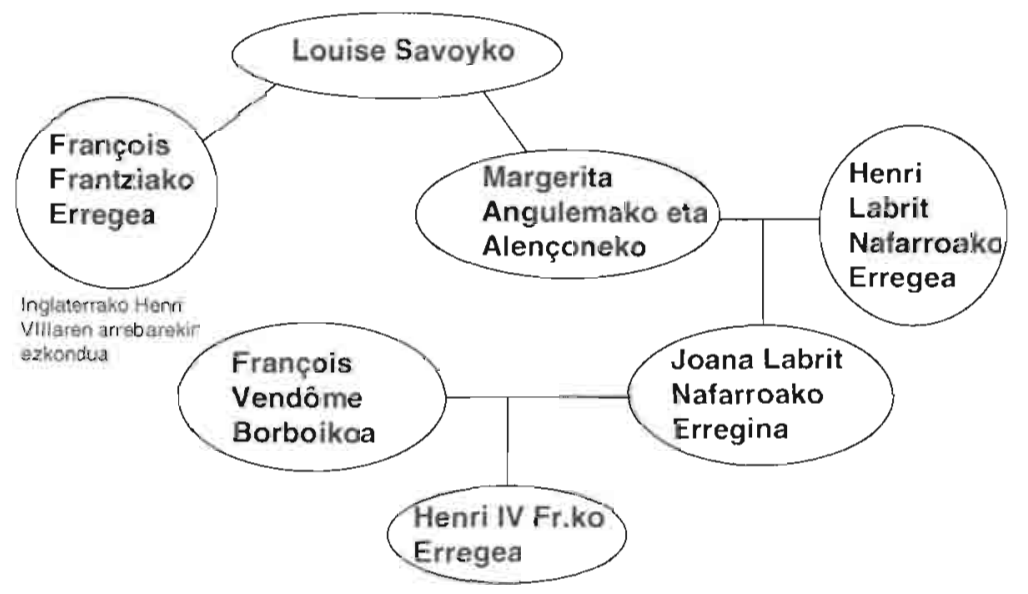

Testuaren iturriei nagokiela, hiru aldaki izan ditut begien aurrean:

1/ Ingalaterrako Elizabeth I erregina izango zenak hanaika urte zituela eginiko ingeles itzulpenaren autografoaren edizio gaurkotua Marc Shellek paratua (1993) Elizabeth's Glass.

2/ Balek 1548an argitaratu zuen itzulpenaren lehen edizioa A Godly Medytacyon of The Christen Soule izenarekin. Lehen edizio argitaratu hori Brown Unibertsitateak egindako edizio elektronikoaren bitartez lortu dut; edizio hori "Women Writers Project"en dago The Renaissance Women Online Collection orrian. (Ikus bukaerako erreferentzia bibliografikoak).

3) Le Miroir de l'âme pécheresse jatorrizko frantsesa XIX mendeko edizio batetik atera dut: Early Modern French Women Writers bilduman Minnesotako Unibertsitateko Electronic Text Research Centerrek 
(ETCR) berriro argitaratu zuena. (Ikus bukaerako erreferentzia bibliografikoak).

Beraz, bi itzulpen eta jatorrizko bat. Hiru testu horietatik nik aipatu dudan lehenari jarraitu diot batik bat (1993koari alegia). Bilaketa konputerizatu zenbaitetarako 1548 koari begitu diot. Eta azkenik, jatorrizko frantsesa azpian izan dut interpretazioak fidelak ote ziren egiaztatzeko.

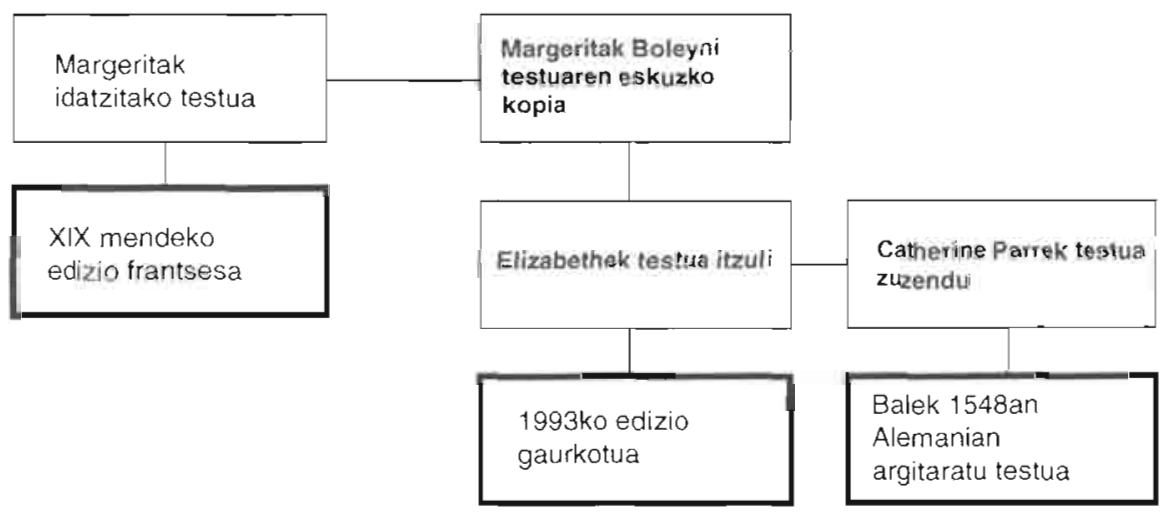

Zeren nabilen edukiaren oinarriko egiturari begitutzen, testu aniztasun honek ez luke arazo larregirik sortu behar, bestera baino, dugun testuaren ulertzea aberastu beharko luke. Oinarrizko testutzat ingelesezko eskuizkribuaren edizioa darabildanez, artikutuaren gorputzean ageri diren aipuak edizio horretatikoak izanen dira. Alabaina, ia beti dakartzat edo frantsese $z$ ko jatorrizkoaren hemeretzigarren mendeko edizioa edo ingelesezko lehen edizio inprimatua, neure erruz leudekeen txarto ulertuak zuzen daitezentzat.

\section{Ethos : Emakumea eta San Augustin}

Aristotelek bere Erretorikako lehen liburuan azaltzen du nola pertsuasiorako indarra edo burutara emateko indarra hiru alderditan jar daitekeen ${ }^{10}$. Hasteko, igorlearen aldean $1 /$ hemen hizlariaren irudi edo autoritatea edo ethos-a lantzen da. Horixe egiten da, adibidez, egunkarietako albisteen hasieran berri agentziaren izena aipatzen denean, Agencia Efe edo dena delakoa. Bigarrenik, indarra mezuan bertan edo logos-ean jartzen denean, esaterako egunkarietan informazioak berri objektibotzat ematen zaizkigunean, halan direlakoan, hots, entzuleria unibertsalari zuzenduak balira bezala ${ }^{12}$. Eta hirugarrenez entzuleriaren iritzian edo pathos-ean oinarritzen denean pertsuasiorako indarra, iritzi artikuluetan "denok dakigu" bezalako formulekin lortzen 
dena, kasurako. Orain bada, Margaritak zelan eraikitzen duen bere ethos-a behatuko dugu.

Margaritak aitzinsolasean dio lanaren egilea emakumea dela, zientziarik eta ezagutzarik bakoa, desioaz baizik ez horniturik. ${ }^{b}$ Ustezko apaltasunaren topikoaz gain - CAPTATIO BENEVOLENTIAE arrunta dirudiena-, ohar gaitezen ezagutza eta desioa elkarri kontrajarrita aurkezten dituela. Alde batetik, testuan bada generoagazko lotura inpliziturik: desioa femeninoa da, eta ezagutza, berriz (nahiz eta kasuan bezala absente egon) maskulinoa. Halan da ze emakumeak desioa daukala, eta aldiz gizonak ezagutza behar lukeela. Lehen pauso honetan autoreak geure sinpatia bereganatzen jardun du; hurrengoarekin bere autoritatea eraikiko du.

Dio autoreak gizonak ez duela ezaguerarik, hain zuzen fedea norberaganatu baino lehen ez baitago ezagutzarik lortzerik. Hementxe dator kritika feministarako interesgunea, hain zuzen fedea lortzeko desioa behar delako, eta desioa, gero ikusiko dugunez, nolakotasun femeninotzat joko duelako testuak. Autorearen deskripzioan, jakituria edo egiaren iturri bakarra jainkoa da, baina gizonak ez dauka bereganatzeko edo jasotzeko jarrerarik, emakumeaz bestela (eta hemen generoen portaera-rolez gain, tartean daude, halaber, genero horiei harreman sexualetan suposatu ohi zitzaizkien rolak ere). Beraz, gizonak egia jaso ezin duenez, egin lezakeen gauza bakarra egiaren birmoldaketa da, hots, erretorikan jardutea. Halan da ezen, autoreak rhapsodo ezjakinaren papera harturik errebelazioa egin zaion profetaren gisa azalduko zaigula. Fedea hiru mailatan iradokiko du autoreak: maila sexualean, jakintza mailan eta maila erlijiosoan: hiruretan, fedea desioarekin berdinduz gero, harrera aktibotzat jorik.

Orain goazen astiroago izenburuan agindutako San Augustinen testuingurura. Margaritak baieztatzen du gizonak Fedea baino lehenago ez duela "onta-

\footnotetext{
h Si vous lisez ceste oeuvte toute entiere. Arrestez vous, sans plus, à la matiere. En excusant la rhythme ef le langage. Voyant que cest d'une femme l'ouvrage. Qui n'a en soy science, ne sçavoir. Fors un desir, que chacun puisse voir Que fait le don de DIEU le Createur. Quand il luy plaist justifier un coeur:
}

1548ko ediziotik: If thu do throughly reade thys worke (dere frynde in the lorde) marke rather the matter than the homely speache therof, consyderynge it is the stodye of a woman, whych hath in her neyther connynge iror scyence, but a fervent desyre that yche one maye se. what the gifte of God the creatour doth whan it pleaseth hym to justyfye a hart. 
sunaren ezagutzarik, Jainkoaren botere eta jakituriaren berririk. Egia ezagutu bezain laster, orduantxe du [gizonak] bihotza maitasunez eta karitatez beterik":

"...knowledge of the goodness, of the wisdom and of the power of God. As soon as he knoweth the truth, then is his heart full of love and charity."c

Bertute augustindarrak - fedea, itxaropena eta karitatea, (edota paulindarrak, filologiak zuen erreformisten testuinguru historikoan pertinenteagoak izan litezke eta) - testu osoan zehar ageri dira. Honen aurrean badira gogoan hartzeko hausnar-bide garrantzizko bi: alde batetik erretorikak edo antzinate greko-latindarreko tradizio literarioko erlazioek kristau tradizioan lituzketen kideak eta, bestetik, hermeneutika abiagunea izendatuko dudana, hots, zelako jarrera izan behar duen testuari hurbiltzen zaionak.13

\section{Harreman erlazioen kidetzea: AEQUALITAS}

Eragin paulindarrak alde batera utzirik, nire abiapuntuko suposamendua da San Augustinen bertute teologikoak eurenez kontzeptu erretoriko batzuen moldaketa direla, izan. Har dezagun ÆQUALITAS kontzeptua, konparazioa denez gero, antonomasiazko erlaziotzat jo baitezakegu. Cicerok bere Topican EQUALITAS kontzeptua hiru erlaziotan zatitzen du:

pietatea edo zeruetako jainkoekiko erlazioa,

errespetua edo joandakoen izpirituekikoa, eta

justizia edo hauzutasuna edo gizakien artekoa.

Hirukote hori erraz berrantola daiteke honetara:

fedea: azpikoazindik goikoarenganakoa,

karitatea: goikoarengandik azpikoarengana, eta,

esperantza: berdinen artekoa.

Ohar bedi irakurlea itzuhtzaileak metri causa sartu duen lerro horrek daukan berdintasunaren aldeko bindikaziozko itzalaz (batez ere kontutan harturik emakume batek diotsola gizon bati): "dear friend in the Lord" Jainkoagan lagun-senide-kide maitu.

c Quel est le coeur d'un homme, quant à soy.

Avant qu'il ayt receu le don de Fay,

Par lequel seul l'homme a la congaoissance

De la Bonté. Sapience et Puissance.

Et aussi tost qu' it congnoit Verité.

Son coeur est plein d'Amour et Charité

1548: For what is the hart of a Marı, concernynge hys owne strength, before he hath receyved the gift of faythe? ["]Therby only hath he knowledge of the goodnesse, wysedome, and power of God. And as sone as he through that fayth, knoweth pythely the truthe hys hart is anon full of charyte and love. 
Ohar gaitezen nire kidetzea. ez dela guztiz biribila. Erretorikako hirukotean ekile bakarra gizakia zen. Hirukote kristauan agentzia alda daiteke baldin eta hierarkia errespetatzen bada. Bestela esateko: berridazketa kristauan azpiko maila sortu da, eta goiko maila, berriz, soildu. Dena den, testu honen arazo nagusira artez garamatzan kontu inportantea zera da, pietatea desagertu egin dela, hain zuzen irudi katolikoetan Mariak pertsonifikatuko duena ${ }^{14}$. Cicerok eman berdintasunaren definiziotik gure bigarren kidetzera dagoen aldea hauxe da: fedeak pietatea ordezkatu du ${ }^{15}$. Orain noan seinalatzera testuan dauden harreman-funtzioak:

arimaren fedea jainkoarenganako,

graziaren emaría eta

Jesusen karitatea arimarenganako.

Horiexek dira arima-jainkoaren arteko hartu-emanen arauak testuan. "Harreman funtzio" terminoarekin bi agenteen arteko hartu-emanen. kontzeptualizatzea adierazi gura dut. Hartu-eman horrek bakoitzaren funtzioa definitzen du erlazioan bertan, etaledo kide batengandik bestearengana truka daitekeen objektuaren nolakotasuna. Kasu honetan objektu bezala kontzeptualizatzen den trukaketarako gaia grazia da, objektu hori jasotzeko hartzaileak erakutsi behar duen jarrera fedea da, eta objektu hori ematen duenak bere azpikoari erakusten dion jarrera karitatea da.

\subsection{Abiagune Hermeneutikoa: fedea-desioa}

Augustinek bere Kristau Doktrinan Eskrituren ulerkuntza sinpatikorako, hots, Eskriturak irakurri aumetik noraezeko den gogo-jamera lortzeko, arako bertuteak proposatzen ditu: fedea, esperantza eta karitatea 16 . Margaritak ere berdin, gogo-bihotzen argitze jainkotiarrari loturik darabiltza beti bertuteok, hau da, bestela ulertezina zatekeen ezagutzari loturik. Leheñ aipatu testukira itzultzeko, badakusagu zelan genero biak ala biak ere ezjakinean dauden baturik, eta elkarrekin harremanetan jarriak fedea dela medio; fedeak ematen baitu ezagumendua. Labur esan, gizona erretorikaren jabe da, baina ez du ezagumendurik, emakumeak, berriz, ez daki erretorikarik baina desioa dauka. Desioak azpian daukan irudi-eskema 17 ontziarena da: bada. iturburu bat, desiratutako gaia isurtzen duena, eta bada hartzaile bat, desiratutako gaiaz betetzeko prest dagoena. Bestalde, emakumeari sexu harremanetan egotzi izan zaion rola hartzaile (pasibo)arena izan da. Desiratzea objektu bat hartzeko prest eta irrikatan egotean datza; hortaz, fedea sexualki ulerturik desioa da. Ikuspegi tradizionalean gizonaren rola aktiboa izanik. 
horrek berorrek eragotzi egiten dio Jainkoaren jakituriak argitua izatea. Margaritak liburuaren hasieran bere generoa aipatzen zuen bere burua apaltzeko, baina hara non arrazoi berberak balio duen oraingoan egilea goresteko.

Testua hasi bezala bukatzen da, Jainkoaren maitasuna ulertzeko edo adierazteko idazleak duen ezintasunaren gaineko hausnarketa erretorikoarekin ${ }^{18}$. Augustinek esaten zuen ebanjelizatzailearen elokuentzia edo etorria nahikoa ez zenean, erretorika libururik onena Biblia bera zela, eta beraz gomendatzen zuen hura buruz ikasi eta hango hitzekin hitz egitea, zeren Bibliak izan behar baitzuen inon den erretorikarik egokiena edo audientzia guztiei "egokituena" (Septuagintaren azalpen mitikoa) 19. Beraz, Margaritak ere berdin egingo du: "Ez dut ezagutzarik (...) Adierazteko biderik ez (...)", baina, halan eta ere "zeren hain nagusi onaren ontasuna isilduko lukeenak bekatu egingo bailuke.... erdu, beraz, nigana O Paul zorionekoa...".

"I have no knowledge (...) The impossibility of the declaration (...)," but yet "...for he that would hide the goodness of so good a master should commit a sin...Therefore come, O happy Paul..."d

Edolan ere, autoreak hasi bezala eman dio amaiera aitzinsolasari, maitasuna eta "desiratzeko esperantza" ezein gizonen jakituriatik bereiztuz eta aldenduz: "...gure bihotza, maitasuna eta esperantza bultza ditzagun desiratzera inongo gizonak ikusi, igarri edo pentsatu ezin duen hori..."

"...to draw our hearts, love, and hope to desire this which no man also can either see, feel, or think..."

Labur dezadan: heuristikaren aldetik, INVENTIO edo sorkuntzaren aldetik alegia, bertute agustindarrek eta topikoek eginbehar bertsua dute. Topikoak argudioen jesarleku izendatu ohi ziren; (filosofia edo lege) arazo

\footnotetext{
'Donc, attendu qu'un sy tresgrand Apoustre Comme saint Pol n'a voulu parier oultre,

Suyvant. ke trae de sa tressage eschole

Je me tairay: mais, suyvant sa parole

(Bien que je sois fein, poudre, ordure el fange).

Ne puís faillir à rendre la louenge

De tant de biens, qu'avoir je ne merite.

Qu il luy plaist faire â moy sa MARGUERITE.
}

1548: Therfor come. O happy Paule, whych hast tasted so moche of the same swete ho nye, beynge blynded for the space of thre dayes, \& rapte up unto the thirde haven. Now 1 besech the, satisfye my ignoraunce \& faulte. \& tel me what in suche vysyon thu hast seane.

e O lheureux don, qui tait thomme DIEU estre, Pseau. 81

El posseder son tant desirable Estre. 
baten inguruan argudioak bilatzeko hausnar-bideak izan ohi ziren. Topikoek hermeneutika edo interpretazioaren aldetik (legea) desanbiguatzeko balio zuten; hots, testuko balizko kontraesanak argitzeko. San Augustinen bertuteek ere berdin egiten zuten - nahiz eta iturrien trantsitibitateari buruz ez dudan baieztapen zehatzik egin, Cicero dut gogoan - baina, autoritatearen kontzeptuarekin loturik, bazuten ordain moralik. Zuzen interpretatzeko testuari erabateko autoritatea aitortu behar zaio eta irakurleak bere burua testuaren azpitik ezarri. Horrela irakurleak sortu dituen hipotesiak testuaren hurrenkerak arteztuko dizkio, testuan bertan ez baitago kontraesanik, eta txarto ulertuak irakurlearen erantzukizuna baitira. Testuaren autoritatea onartzeko fedea behar da, esaneko ikaslearena alegia, hartzeko pronto dagoenarena. Sorkuntzaren aldetik ere berdin, idazteko abiapuntua eta argudioen jesarleku edo eragilea karitatea izan behar da; idatziko dugun testuak baino gutxiago dakien bati irakastea da helburua. Ekintzen munduan ere berdin: gure ekintzak Jainkoaren nahira makurtu behar dira eta horretarako gure borondatea malgua izan behar da (hauxe da erreformazaleek berreskuratu nahi duten kontzeptua). Maila biok, intelektuala edo epistemikoa eta pragmatikoa edo jokaerena, lotuta daude bai "testamentu" hitzaren polisemiaren bitartez, bai kristauen jainkoa jainko intelektual bezala ulerturik.

Baina, gure testurako, batez ere Etxeparek aurkezten digun eszenarekin kontrastatzeko, funtsezko suertatzen zaiguna zera da, borondatearen kontzeptualizazioa bekatuaren arazoari loturik. Hurren ikusiko dugu nola.

\section{Epaiketa eszena: llegea eta barkamena}

Sarreran esan dudan bezala, Margaritaren obra osorako metaforasorburu nagusiak bi dira: familiarteko harremanen eszena eta epaiketaren

\footnotetext{
Helas ! jamais nul ne le peuli entenure,

Si par ce don n'a pleu a DIEU le prendre.

Et grand raison ha celuy den douter,

Si DIEU au coeur ne luy a fait gouster.

Mais vous. Lecteurs de bone conscience.

Se vous requiers, prenez la patience

Lire du tout ceste oeuvre qui n'est rien,

Et n'en prenez seufement que le bien.

Mais price DIEU, plein de bonté naìve,

Qu'en vostre coeur il plante la Foy vive.
}

1548: He wylleth us also therin to esteme, that he neyther can declare nor yet name it, \& so to geve forth our hartes to pacyence \& hope of that thynge whych never man yet coulde se, neyther yet dyscerne. what though many through love for it hath dyed. 
eszena. Metafora sare biok harreman- funtzioaren bidez josi zaizkio elkarri, kontratuaren ideiaren bitartez. Kontratua apuitzen bada, berba jaten bada, bekatua izan zein krimena izan, legea aplikatu egin beharko da. Bai katolikoen eta bai erreformisten ikuskeran gizakiak bere izaeragatik beragatik huts emango du, eta bekatu hori garbitzeko borondatezko keinu bat egin behar du. Katolikoen kasuan keinu hori norabidea aldatze bezala kontzeptualizatuko da, ama birjinagana bihurtzea, alegia. Bestela esan, legea hautsi izana barkatzeko mesedea eskatuko zaio Jainkoari Mariaren errukia edo pietatearen bitartez. Bestalde, erreformisten irudian, bekatariak borondatea malgutu behar du Jainkoarenarekin bat etor dadin; bekatariak bere borondatea Jainkoaren testamentura ekarriz gero, malgutasun horrekin fedea erakusten dio Jainkoari eta hark karitatezko obra bat egingo du gizaki hori salbatzeko graziaren opariarekin.

Hori halan denentz ikusteko, zati honetan epaiketaren irudiaren alderdi batzuk aztertuko ditut, Etxeparek eskaintzen dizkigun lor̃atzei eutsita. Aztertu behar ditugunak hiru arlo hauetan sartuko ditut: zelan kontzeptualizatzen dugun legea eta zelan ageri den legea kontzeptualizatuta erlijio testuetan, zein eginkizun edo rol hartzen duten erlijio testuetako pertsonaiek epaiketaren eszenan, eta zeintzuk diren aurreko sailean landu ditugun erlaziofuntzioei aplika dakizkiekeen propietateak.

\subsection{Legearen kontzeptualizazioa eta azterketa kognitiboa}

Linguistika kognitiboaren mugimendua laurogeigarren hamarkadan hasi zen 20 . Eta hasi zen metaforari so eginez, esanez metafora ez zela ez literarioa soilik ez arbitrarioa sortzez, ordea gure eguneroko hizkeran metaforak erabili ohi ditugula oharkabean. Baina oharkabean egote horrek ez dituela desmetaforizatzen; katakresiak ez dakarrela halabeharrez metaforaren desagerpena, metaforaz ez ohartzea baino. Halan da ze hizkuntzalariok heldu zirela erakustera zelan eguneroko hizkerak oinarriko metafora kontzeptualak dituen, zeintzuen bitartez hedapen semantikoa eta polisemia gertatzen diren. Oinarriko metafora kontzeptualen azterketa Lakoff eta Johnsonen eskutik etorri zen ${ }^{21}$. Esan daroadan legez, oinarriko metafora kontzeptualak eguneroko hizkuntzan erabili ohi ditugun kontzeptuen sarea sustaizen duten metaforak dira 22. Halaxe erakusten dute honako adierazpideek, esaterako: "ez dut bat ere argi ikusten kontu hori," edota "azalpen iluna eman zigun" edota "begi-bistakoa da", edota Bermeoko kantan bezala "egije da...neuk ikusi dotelakon", non egia erreferentea begizko ohartzeari lotzen zaion, eta ez entzumenari, adibidez, eta abar 23. Adierazpen guzti horien azpian dagocna JAKITEA IKUSTEA DA metafora dugu. 24 


\subsubsection{Zuzena vs. okerra}

Orain begira diezaiegun legearen eremuan erabiltzen diren berba ez-tekniko batzuei beste hizkuntza batzuetan: ingelesezko "right(s)", edo frantsesezko "droit(s)", edota espainolezko "derecho(s)". Honek erakusten digu etimologia, polisemia eta hedapen semantikoa (metaforikoki) motibaturik daudela; har dezagun kontuan zelan dauden loturik bai etimologikoki bai semantikoki DIRECTUM eta RECTUS: zuzena, legea eta eskoia. Euskaraz "zuzenbidea" daukagu, baina baita "gizon arteza" edo "gauzak zuzen" edo "bide okerretik doa hori" edo "okerreko samatik" bezalako adierazpideak ere: okerrak eta zuzenak zama axiologikoa daukate, hau da, legea ona bada "zuzena" izango da, eta gure ekintzak txarrak badira "okerrak" edo "makurrak" edo "bihurkeriak" izango dira. Bestalde, oraingoz aipatu besterik ez baina, gorde dezagun gogoan gerorako zuzentasunarekin eta okertasunarekin batera datozela zurruntasuna eta malgutasuna: zuzena denari zurruntasuna suposatzen zaio, eta okerrari, behintzat momenturen batean, malgutasuna. Lotura hauek gera azalduko ditudan korrelazio metaforakaz daukate zer entenidurik.

\subsubsection{Bidea eta Legea}

Aurrekoarekin batera, badakigu euskeraz legeaz jarduteko "bide" esparrua darabilguna. Esate baterako "zuzenbidea", "eskubideak" edo "bidezkoa" egunero erabiltzen ditugun esapide metaforikoak dira. Etxeparek adibidez:

"Beccatore guira eta mira eztaquigula / Balinetan vide gabe acusatu baguira".

Nola lotzen diren legea eta bidea arazo korapilotsuagoa da; alde batetik bidea bizitzari lotzea arras arrunta da, behintzat Europako mendebaldean, BIZITZA BIDAIA DA (LiFE is A JOURNEY Lakoff \& Turner 1989) oinarriko metafora kontzeptualaren bitartez 25 :

- Bizitzan helburuak daude, bidaiako helmugak bezala,

- Bizitzak hasiera bat dauka, bidaiaren abiapuntua bezalakoa,

- Bizitzan gertaerak suertatzen dira, bidaian bezala,

- Eta azkenik bizitzan denbora igaro doa, bidaian lekuak igaro doazen legez.

Helburuak eta helmugak lotuta badaude, bidea helburu horietaraino heltzeko modua izango da. Beraz, hemendik lotu daitezke bidea eta legea, 
biak dira zerbaitetarako modu; bidea "modu" edo "kera" bezala ulertu behar da lehenago, eta legea prozedura bezala, eta biak lotu 26 . Gure kulturan eta hizkuntzan bizitza bide bezala aditzera ematen digun oinarriko metafora kontzeptuala daukagulako, hain zuzen, uler ditzakegu "bizitza/bizimodu txarra" = "bide txarra" bezalako kontuak. Behin kuitura batean legea eta bidea bateraturik egonez. gero, biek izan ditzaketen propietateak lotzeko ere jauzi txiki bat baino ez dago: bidea arteza edo zuzena, eta legea ere arteza edo zuzena, bidea okerra edo makurra eta abar. Gainera - eta hau inportantea izango zaigu aurrerago azalduko dudan volitioaren esparturako- bideari eutsi ala bidea uztea borondatezko ekintzak dira. Beraz, "bide" esparruari begiratu ahal diogu testuan diren legeari buruzko metaforak azaleratzeko, eta ikusteko zeintzuk diren termino horren azpian izendatutako kontzeptuak. Etxeparerengandik hartutako adibide batzuk emango ditut, honako esanahi hauek ageri dituztenak: zuzena, aukera, baimena, zilegia, [in]justizia, antza denez 27:

- Erregueren aduocatu videzco eta nobleari

- Eta orduyan çuc ydaçu indar eta gratia / Beccatuyez vqheyteco vide dudan doluya / Perfectuqui eguiteco neure confessionia / Neure beqhatuyez oroz dudan varqhamenduya

- Herri orotan gauça oroz eztu vere paria / Othoyce bat baneguyon larradala eguia / Biderican liçatenez nynzan haren gracian

- Hiri eguin vadaraye bidegabe handia / leyncoari gomendezac eure gauça gucia / Harc orori emanen dic bere merexituya

- Horla erraytia errax duçu erho bocen vadaquiçu / çure pena dioçunoc nonbayt handi videytuçu.

- Nic oguenic eznuyela honguiguitez verceric / Bidegabec haritu nu vide eznuyen leqhutic / Erregueri gayzqui saldu guertuz oguen gaberic.

- Nic vaycitut offensatu bide eztudan veçala.

- Nola dugun cerbiçacen hanbat gure exaya /langoycua desconoci gure saluaçalia / Eta oroc eçagucen dela videgabia

- Pensa othoy nola gauden bi bideren erdian / Salua bano damnaçeco perileco punduyan / Ehor fida eztadila othoy vanitatian

- Secretuqui minçaceco othoy bide: ydaçu

Etxepareren poemak ikertu nituenean, ikasi nuen legea gainditu beharreko oztopo edo langa gisa ageri dela testuan; salbaziorako bidea lotuta dago zabaldu edo itxí egiten den atearekin, eta bidean aurki genizakeen oztopoak 
bide hori itxi diezagukete: "Orotaric cerraturic daude paussu guciac". Hau ulertzeko bizitza bidaia bezala hartu behar da, eta bidaiaren bukaeran atea edo itzulinguratu beharreko gunea. Baina ikuspegi osoago bat jadesteko epaiketa horretan Jainkoak eta Mariak eta bekatariak berak zein rol hartuko duten aztertu beharko dugu. Alabaina, hori baino lehenago legearen kontzeptualizazioaren azken alderdia ikertu behar dugu.

\subsubsection{Zurruntasuna eta malgutasuna: korrelaziozko metaforak}

Korrelazio metafora Joseph Gradyren Foundations of Meaning doktorego tesitik maileguan harturiko kontzeptua da. Gradyk, linguistika kognitiboak metaforari eman izaten zion garrantzia eta lehentasunari jarraiki, oinarriko metafora-lehengaiak aztertu ditu bere tesian. Hasteko bereizi ditu alde batetik tradizioan luze eztabaidatutako metaforak (Akile legoi bat da), eta bestetik "inflazioak gora egin du" diogunean, adibidez, azpian legokeen GEHIAGO GORA DA oinarriko metafora kontzeptualak bezalakoak, zeinetan kantitatea altueraren arabera kontzeptualizatzen den. Zehatzago esan, lehen aipatu ditudan oinarriko metafora hauetarako bi eratako motibazio iturri bereiztuko ditu: alde batetik antzekotasuna - eta era horretara Gradyk gaurko ikuspegitik berreskuratu nahi izan du arbuiatua izan den baina Aristotelerengandik datorkigun tradizio bat-, eta, bestetik, korrelazio metaforak 28 . Korrelazioz eraikitako oinarriko metafora gure esperientziaren bi esparru lotzeko gertatzen den metaforari esaten zaio ${ }^{29}$. Esaterako, "trigonometria total egiten zait aldats gora oso" esapidean, aldats bat igokeran dugun esperientzia eta arazo bati aurre egikeran dugun esperientzia lotzen ditugu, eta beraz, mundu fisikotiko adierazpena mundu intelektualari aplikatzen diogu 30. Beste adibide batzuk "astuna" edo "latza" izan daitezke, eta abar.

Bidearen metaforak salbazioarekin eta legearekin batzandukeran bi tasun bereganatzen ditu: malgutasuna edo biguntasuna, eta zurruntasuna edo urrikalgaiztasuna. Gure kasuan zurruntasun fisikoa sentitzen dugun modua litzateke bestelako zurruntasun moral edo psikologikoak adierazteko sorburua (Grady 1998). Biguntasun eta malgutasunaren kontzeptuak gure eguneroko esperientzian oinarri harturik lotzen ditugu: gauza bat biguna da guk egin diezaiokegun presioari erresistentziarik jartzen ez dionean. Antzera, gauza bat malgua dela diogu gure presioaren pean forma aldatzen duenean. Esperimentu txiki hau egin dezakegu: "hartu nuen alanbre bat, saiatu nintzen okertzen, eta azkenean lortu egin nuen...Zelan zegoen alanbrea nik hartu baino lehenago?" Erantzun automatikoa "zuzen" izan ohi da, nahiz eta berez alanbre okerra bihurtzen saia nintekeen. Joera hori segurutik formen hierar- 
kia kultural bati lotuta dago: suposatzen dugu hasierako forma zuzena dela, eta eratorria (hots, indar egin eta gerokoa, edo higatua, etab.) okerra. Beraz zuzenak zurruna dakar eta okerrak malgua.

Bestalde, "egitarau edota ordutegi malgua" daukagula esan ohi dugu, edota halako eta holako erakundea oso zurruna (edo zorrotza) dela 31 . Holako adierazpenen oinarriko metafora kontzeptuala, oso maila orokor batean, hauxe da: ERAKUNDEAK EGITURA FISIKOAK DIRA (Grady 1997). Erakunde eta entitate abstraktuak beratasun fisikoaren arabera ulertzeak badu bere parekorik esparru erretoriko-forentsean equitas bezala. Izan ere, Eden aipatu dudanean nioen legez, equitas delakoaren bidez lege orokorra errealitatera makurtu edo kasu konkretuari egokitzen zaio. Justizia kontu-liburu, balantze eta matematikaren arabera kontzeptualizatzen dugu. Ildo horretatik, kontu matematikoen finkotasunari emaitzen zurruntasuna dagokio, eta kontu-liburuaren emaitza epaiketako epaiarekin lotzen dugu, hots, akusatuak jabegoan bildutako bekatu edo krimenei dagokien zigorrarekin. Legea izatez zurnuna da (cf. dura lex, sed lex) baina legearen aplikazioa edo egokitzapena - equitas edo hauzutasuna edo berdintasuna, alegia - malgua da, eta berdin errukia, gupida eta barkazioa.

"Biguna" Ama Birjinari egotzitako adjektibo tipikoa izango da euskal literaturan ere, cf. J. J. Mogelen "Ama biguna" eta paradigma unibertsalago batean xamur adjektiboa ere. Xamurtasuna ere malgutasunari edo presiopean forma aldatzeari dago lotuta. Hemen gako hitza "sentibera" litzateke, eta ziur aski erreakzionatzearen ideia ere oso lotuta egongo da. Erreakzioa edo erantzunezko portaera sentimenduarekin edo sentibera izatearekin erlazionatzen da; forma aldaketa, berriz, kanpoko estimulu baten aurreko erreakzio mota bat da, haragi malgu edo xamurraren kasuan bezalaxe. Ezagutzen ez ditudan arrazoiengatik, malgutasuna estuago lotzen zaio forma aldaketari, eta xamurtasuna, aldiz, sentiberatasunari.

\subsection{Azken epaiketako Pertsonaien rolak}

Judizio Jeneralaren eszena nagusietan, ama bigun hori legea gainditzeko bidexkak oso ondo ezagutzen dituen abokatu bilakatuko zaigu. Etxepareren hitzetan ostera ere, "Ceru eta lur ororen erreguina dignia | Beqhatoren aduocata eta confortaria". Bere funtzioa equitas eta mesedea da, hots, egokitzearena. Orain goazen begiratzera sofistikazio handixeagoarekin Etxepareren hurrengo pasarteari, zati honetan pertsonaia nagusien eginkizunak erabat zehazturik ageri baitzaizkigu: 
Beccatoren saluaceco ieyncoac eguin cinducen / Bere buruya eguin dici iuge iusticiaren / çu misericordiaren refugio cinaden / Nola berac iustician ecin salua liçaque / çure misericordiaz remedia litecen / Balinetan eguiazqui çugana gin valite

Etxepareren lerro hauetako metafora-sorburua estasi edo egoera juridiko-erretorikoa da. Bertan Jainkoaren eta Mariaren rolak azaltzen zaizkigu argi eta garbi: aurrenarena epailea, hurrenarena abokatua. Alde batean, Jainkoak bere burua izendatu eta egin du epaile. Bestean, Jainkoak Maria egin du errukiaren (mesedearen) aterpe, eta bere burua epaile. Hori horrela izanik, ez zen ba errazago izango Jainkoak berak, hots, epaileak berak bekataria zuzenean salbatzea halako sotilkerietara jo barik? Horri erantzuteko, kontuan har dezagun justizia edo zuzentasuna zurruna dela zuzena delako, zeren biguna etat malgua balitz okerra bailitzateke, goian ikusi dugun bezala. Legea zurruna denez, ezin du barkatu, ezin da makurtu, eta barkamena beharrezkoa da salbaziorako. Edozein kasutan, zurruntasuna versus barkaberatasuna bikoteak ematen diguten irudi orokorra kontzeptu oinarrikoago batzue$\tan$ datza:

- Zuzentasuna errukiaren (mesedearen) kontrakoa da

- Salbatzea barkatzea da

- Beraz, barkatzea legea ez ezartzean daiza

- Hortaz, bat salbatua izateko beharrezkoa da legea saihestea

- Legea saihesteko modua ararteko baten bitartekotza eskatzea da

- Legea bideko oziopo edo langa bezala ikusten da, eta arartekoa berriz, hesi horren itzulingurua nola egin edo legearen gainetik nola pasatu dakiena da (esan nahi baita, hesiaren beste aldera heltzeko, Zerura, segurutik).

- Jarduera honetan esku hartzen duten propietateak biguntasuna versus zurruntasuna izan daitezke. Interesgarria da ikustea nola propietate fisiko horiek proiektatzen diren giza ezaugarrietan eta nola erlazionatzen den barkaberatasuna biguntasunarekin

Deskribatzea falta zaigun azken pertsonaia bekataria bera da. Goiko testukian oso argi ageri zaigu zein den salbaziorako baldintza: "çugana gin valite". Esapide horren azpian dagoen kontzeptualizazioa dendatuko naiz argitzen hurren. Har dezagun Etxepareren honako pasartea:

$\mathrm{O}$ andere gloriosa eta ama eztia / çutan dago beqhatoren sperança gucia | Ni çugana nyatorqueçu beqhatore handia | Arimaren saluacera çu çaquiztan valia. 
Berriz ere "zugana", hots, adlatiboa eta mugimenduzko aditz bat. Definizioz guraria erakusten duten adizak lekuz aldatzeko aditzak dira, mugimenduzkoak; eta hori jazartzen zaio subjektu-objektuaren berezko nolakotasunari 32. Guraria eta norabidez aldatzearen arteko harremana honctara eman daiteke: INTENTZIOA NORABIDEZ ALDATZEA DA Eta INTENTZIOA NORABIDEA DA, 33 Honi loturik esan genezake norabide bezala kontzeptualizatutako intentzioa korrelaziozko metafora dela. Hori sendo baieztatzeko pareko adibideak aurkitu beharko genituzkeen, esaterako IN-TENDERE joera (preposizioaz) bideratua bezalakoak alegia.

Ikus dezagun beste adibide bat, adlatiborik eta mugimenduzko aditzik erakusten ez duena:

çutan dago beccatoren remedio gucia: | Sperança ossagarri eta saluamenduya / çuc guibela demaçuna nola vayta galduya / çure gomenduyan dena halaver da salbuya.

Alde batetik "gibela" bera badago metaforikoki erabilita - edo, hobeto esan, metonimikoki erabilita, esparru beraren barruan gertatzen baita proiekzioa-, nahiz eta hiztunak holakotzat ez jo: maila fisikoko organoa "atzea" esateko erabili da ${ }^{34}$. Baina gainera, edozein hiztunek badaki atzea edo gibela eman esapideak "bazter utzi" esan gura duela. Beraz, laguntzarik ez ematea edo atentziorik ez ematea, atzea edó gibela ematea baldin bada, atentzioa ematea gorputzaren aurrealdean egon behar da kokaturik, agian aurpegian bertan ("aurre egin" etab.). Atentzioa zuzen daiteke, eta lotuta egon behar du zuzen daitezkeen zentzuei. Iritzi batean ezingo genuke atentziorik erakutsi zuzendu ezin diren zentzuetan oinarri harturik, usaimenari edo dastamenari loturik, alegia. Ohar gaitezen adibidez zelako esapideetan ageri den "begi" hizkia: "begi ederrak egin", "begiramen" begirune", "norbaiten begira egon" etab eta hauetako zenbaitetan ageri den atentzioari edo zentzu zuzenduei loturiko esanguraren bat. Interesgarriro, atentzioak badu zerikusi etimologikorik intentzioarekin. Beraz: INTENTZIOA NORABIDEA DA, NAHIA NORABIDE ALDAKETA DA, UTa ATENTZIOA AURPEGIAREN (EDO GORPUTZAREN AURRE ALDEAREN) NORABIDEA DA. Eta zer egin behar du bekatariak testuinguru katolikoan? Ama birjinagana bihurtu bideari utziz, eta abar. Intentzioa erakutsiz gero Andre Mariak bilatuko dio zirrikituren bat legeari itzulingurua egiteko, Jainkoa bigunizeko, edo, bestela esanda, mesede edo errukiaren bitartez epaiketa irizpideak aldatzeko.

Irudi hau bat dator generoaren bereizketarekin: legea zurruna eta maskulinoa da. eta malgua edo biguna edo errukia femeninoa da. Mirailaren jomugetako bat eskema hau aldatzea izango da. "Helas, Jesus ona! Ikusten zenuela nire itsutasuna, eta nire beharrean ezingo nukeela gizonengandik 
laguntzarik izan, nire salbaziorako bidea zabaldu zenuen. O zein ontasun eta eztitasuna! Ba ote da aitarik alabarentzako, edo bestela, nebarik arrebarentzako, Berak egin duena inoiz egingo lukeenik? (...) Helas! Zeuk maite izan duzu. O karitatea, sutsu eta sugartsua, zu ez zara batere laxoa maitatzen; guztiak maite dituzu, bai horixe, baita zure etsaiak ere, eta irainak barkatu ez eze, zeure burua eskaintzen duzu heriotza, gurutze, neke, min eta oinazean (euren salbamen, libertate eta askatasunaren alde) "

"Alas, good Jesus! Thou seeing my blindness and that at my need I could have no succor of men, then didst Thou open the way of my salvation. $O$ what goodness and sweetness! Is there any father to the daughter, or else brother to the sister, which would ever do as He hath done?f (...) Alas! Thou hast loved her: O charity, fervent and inflamed, Thou art not slack to love; Thou which lovest everybody, yea, and also Thy enemies, not only forgiving them their offenses but also to give Thyself (for their salvation, liberty, and deliverance) to the death, cross, travail, pain, and suffering.:

Testu honetan bide zabalari edo zabalduari buruzko aipua dugu. Kontratu apurtuaren sare kontzeptualean atea itxita dago, eta itxita egon behar da arimak bere duen bekaturako isuriagatik. Baina, kasuan Katolikoekin gertatu ohi zenaz bestera, Jesusek, eta ez Mariak, zabaldu du atea. Holako ontasunerako zioa honetara ematen da: konparatzen dira Jesusen arimarekiko hartu emanak, karitatea dela medio, familia artekoekin: aita alabaganako, eta neba arrebaganako.

\footnotetext{
f Las! bon JESUS, voyant ma cecité,

Et que secours en ma necessité

Ne puis avoir d'aucune creature. Actes 4.

De mon salut avez fait l'ouverture.

Quelle bonté, mais quelle grand douceur!

Est il pere à fille, ou frere à socur,

Qui un tel tour jamais eust voulu faire.

Tant fust il doux, piteux et debonnaire:
}

E Sans vous aymer, las! yous l'avez aymée.

O charite ! ardente et enflammée.

Vous n'estes pas d'aymer froid ne remis.

Qui aymez tous, voire voz ennemis ;

Non seutement leur youlant pardonner

Leur grefve offense, ains vous mesmes donner

Pour leur salut, liberté, delivrance,

A mort et croix, travail, peine et souffrance. 
Ingurune katolikoan. Mariaren biguntasunak bekatariaren bolizioa erakartzen zuen, Etxepareren adibidean ikusi dugunez; beraz, ekintzaren noranzkoa bekatari maskulinotik (defektuz) ama-abokatu-femeninoarengananzkoa zen. Margaritaren tesiluan, ordea, alde batetik, katolikoen genero rolak aldatu dira - orain maskulinoa goian da, Jainkoa, eta femeninoa behean, arima- eta, bestalde, ekintzaren abiagunea ere aldatu da. Orain goitik beherakoa izango da, Jesusengan hasi eta arimarenganaino, eta Jainkoaren karitate-maitasuna aita-nebek alaba-arrebei lieketenarekin parekatzen da. Bi kokaguneen arteko erlazio-funtzioa karitatea izateak erakusten du oso dela garrantzizkoa erlazio-egituraren mailaketa mantentzea; hots, familia harremanak jaun-basailu esparruaren arabera ulertu behar direla.

Harremanen esparrua birdefinitzeak badakar besterik ere, hots, arimaren eta Jainko-epailearen arartekoak ezabatzea, Janko-aita-senarrarekiko familia harremanen alde; berba batean, sarreran esan dugunez, espazio judizialaren pribatizazioa daukagu: "Ez diot inori eskerrik eman beharrik zeuri baino... [ez bakarrik zuk] barkatu dizkidazulako nite bekatuak, baizik eta graziaren opari artez graziatsua eman didazulako".

"I ought to give no thanks for my salvation but only unto Th''... have forgiven me my sins, but also given unto me the right gracious gift of grace."

Ez da bakarrik legea arima batentzat beren-beregi malgutu dena, arimarentzako berebiziko lege-malgutzea alegia, eta hartara salbuespena egin dela (mesedea-errukia), eszena katolikoan gertatu ohi zen legez; harreman berri hometan trukaketa bat ere badago, hots, bekatuak graziaren truke. Hori azaltzeko ikusi behar dugu senitarteko harremanak zeintzuk diren zalduneria testuinguru batean.

\section{Familia harremanak 35}

Aurretik argi ikusi dugunez, istorioaren narratzailea arima da -arimaren generoa femeninoa delarik, eta gogoan erabilirik ingelesak posesiboez aterantz ez daukala gramatikazko generorik (euskerak bezala), oso itzultzaile trebea agertu da Elizabeth jatorrizkoa horrela bihurturik-arimak autobiografikoki kontatuko dizkigu bere gora beherak.

Esana dago, halaber, Mirailak azpian dituen metafora esparruak bi direla, bata epaiketarena eta bestea familia patriarkalarena. Epaiketaren eszena ez da bere osotasunean inoiz irudikatzen testuan, baina bekatua dagoenetik, batez ere bekatua legearen haustura bezala hartu ezkero, epaia suposatua da; suposatua bai —eta aipu ugari eginda gainera-, baina margotua ez testu honetan. Zelanbait esan, Margaritaren irakurleek gogoan izango 
zuten epaiketaren irudia, oso ezaguna egingo baitzitzaien, ez da, ordea, hori Margaritaren asmoa. Berez, Margaritarenean, epaiketa familia esparruaren barruan suertatuko da, arestian aipatu dudan pribatizazioaren bitartez, eta hori posiblea da, alde batetik, familia patriarkala jaun-basailu esparru metaforikoaren arabera ulertuz gero, bekatua legearen haustura izan beharrean, ituna apurtzea legez hartzen delako, otseinak ugazabarekin duen harremana bertan behera uztea bezala hartzen delako. Esatea legez, katolikoen usterako Maria euren ama bazen, erreformisten arimaren ahaidetzea Jainkoarengana hedatuko da: "ze epaiketa ari dira horiek, baldin epailea gure aita baldin bada!" esanez bezala. Ez zaizkio Jainkoari epaile lanak ukatzen, baina bai legeari leporatzen zaion zorroztasun itsu hori (itsutasunak hain zuzen ez egokitzea esan nahi du, ingurukoak edo zirkunstantziak aintzakotzat ez hartzea alegia), Gainera jaun-basailu erlazioa errazago ekar daiteke merkatal itun batera, eta horixe izango da elestatuko naizen azken eszena. Halan da ezen idazlea zuzenean hasiko dela familiaren esparruan esangura eraikitzen, baina betiere familia patriarkala jaun-basailu botere harremanak kautan harturik. Ikus dezagun nola.

Testuaren eman moduak edo hurrenkerak antolaketa honi jarraitzen dio:

$1 /$ Arimak bere burua aurkezten du, (bataioaren eszenan)

2/ Arima bere lagunartearen arabera definituko da, eta (Familia harremanak I)

3/ Arimak duen jokaera bere lagunekiko eta lagunaren erantzuna bere ekintzekiko. (Familia Harremanak 2)

\subsection{Sendiarekikoak: Jainkoagandik Arimaganakoak}

Erreskadan eman ditudan hiru ataletako lehenari dagokion poema zatiak arimaren nolakotasuna Jainkoarenarekin erkatuta erakutsiko digu. Lehen parte hori, arimak bere burua aurkezten duenekoa, alde batetik orain arterainokoarekin apur batez landu dugun arren ("Helas, Jesus ona..."), geratzen zaiguna beranduagorako utziko dugu, artikuluaren akabutarako, hain zuzen kontratuaren eszenarako. Hala ere, esan dezadan nahikoa arrunta dela arimaren merezimendu gutxia Jainkoak egiten dion begi ederrarekin erkatzea. Aitzitik, bere osotasunean hartuta, poema honek itzulia emango dio eskema horri, eta arima goratuta lotuko da hain zuzen Jainkoarekin dituen harremanetan oinarriturik, hurrengo arauri jarraituz: zenbat eta maila altuagokoak izan zure "ezagunak" halan eta maila goragokoa izango zara zeu ere. "Laguna" sen-ide bezala ulertu behar da testu osoan; lagunak, garai horretan, 
maila sozio-ekonomikoekin daude lotuta, zelako maila halako lagunak, eta, atsotitzak dioen bezala, kontrakoa ere bai, hots, lagunek ernaten dute maila eta prestigioa. Beraz, testuan ageriko diren Jainkoaren ekintzek Jainkoaren ontasuna erakusteko ez ezen, arimaren estatus soziala azpimarratzeko ere balio izango dute.

\subsubsection{Ohorea eta endogamia}

Aristokraziaren endogamia ohoreari buruzko kontzeptuaren ondorioa baino ez zen. Malinak (1993) azaldu bezala bi ohore mota zeuden: metatu ahal zen ohorea edo eskuratua eta metatu ezin zena edo jaiotzatikoa. Gizonezkoek ohorea metatu ahal zuten izen onarekin batera, itzalaren bitartez, ekintza gogoangarrien bitartez eta abar. Horrek luzarora diru iturria ere handituko zuen, baina printzipioz dirua eta ohorea ez zeuden guztiz lotuta. Metatu ezin zen ohorea bat jaio zen familiaren itzalari lotua zegoen. Emakumeek azken mota hau bakarrik zuten, eta ohore hori, nolabait esan, euren himenean zegoen kokatuta. Emakumeek ohorea galdu baino ezin zutenez egin himena urratzearekin batera, saiatu beharko ziren ohorea galtzen eurek baino ohore handiago zuen norbaitekin, baina noski, behin gizonak aginduz gero jabe egingo ziola damari, hau da, aginduta bere ohorean damak ere parte izango zuela. Malinak errekurtso ituri mugatuko gizarte Mediterraneorako azaltzen duenez, hura "gora" egiteko moduetako bat zen, ezkontza politika alegia. Ondorioz, emakumeak edo euren familiaren baitara ezkontzen ziren - ohore kantitate berari behintzat eusteko-, edo goragoko mailetarantz begira jartzen ziren "humanitatea" edo "kondizioa" hobetzearren. Mailarik goren gorena erregea zen, aita izena eraman ohi zuena (horregatik goi mailako handikiek euren artean mintzatzean "anaia" edota "ahizpa" eta abar erabili ohi zuten). 36

Halaxe azal daitezke Margaritak erakusten dituen endogamiako edo intzestuzko harremanak: arima, emakumezkoa den aldetik, dendatzen ari da bere jaiotzatiko ohore kantitatea erakusten, bere "odolaren balioa". Arimaren ohorea berreskuratzeko bideak Jainkoarekin dituen hartu-emanetara eramango gaitu, arimak litekeen eta harremanik estuena daukala litekeen eta izakirik gorenenarekin.

Sendiarekiko harremanei aipua goiko testuan, aitak alabari edota nebak arrebari dion maitasunaren konparaketan mamitzen zen: "Ba ote da aitarik alabarentzako, edo bestela, nebarik arrebarentzako, Berak egin duena inoiz egingo lukeenik?" Oraingotan berriz, bigarren aldian, zenturioi erromatarrak Jesusi etxera joateko eskatzen zioneko aipu Biblikoarekin batera dator- 
kigu. Berriz ere, dikotomia merezi dena vs. jasotzen dena erkatuz lortzen da; merezi dena ezezagun bati legokiokeena da, eta jasotzen dena, aldiz, etxeko bati emango zitzaiona; honen helburua ekintza Jainkoarengandik abiatzen dela esatea da. Kontura gaitezen testuki honek karrajo edo igarobide lanak egingo dituela, alegia pribatizatze prozesu honetan oraindik ere badela bitartekorik —zenturioiak bere semearen ordez hitz egiten du-, eta Jesus ez dela oraindik etxean hartua, hots, oraindik arima-Jesus harremana ez dela zuzena, azken emaitzan izango den legez. Hala ere, etxerakotzeko ahalegina Jesusek egin beharko du: "zeren nahikoa izan beharko bainuke (halako arriskutik atera naizelarik) arrotz bati bezala zuzendua izan nadin; aldiz, zuk ama, alaba, arreba, eta emazte gisa erabili didazu arima (hala esatera ausartu banadi"."

"For it should suffice me (I coming out of such a danger) to be ordered like a stranger; but Thou dost handle my soul (if so I durst say) as a mother, daughter, sister, and wife (117.orr.)."h

Margaritaren bigarren zatiari buruz goian eman dudan ezaupide hura ardatza da: arima goraltxatuko da Jainkoarekin dituen harreman eta tratuak direla bide. Areago, arimak ohorea eskuratu du Jainkoak berak anmari erakusten dion jokamoldeagatik, arima Jainkoak ama, arreba, alaba eta emazte balu bezala tratatuko baitu. Horregatik dator Lukas 15 hurrengo paragrafoan: "Ni, Jauna, ogia eskatzeko on ez naizena, ez eta zure bizilekua den leku goreneko atera hurbiltzeko ere! O zer-nolako grazia den bat-batean zuk niri adeia egin eta nire arima hain gora eramatea, non nire gorputzaren jabe sentitzen den. Pobre, ezjakin eta ahula izanik, ene arimak zurekin aurkitzen du bere burua, aberats, jakintsu eta sendoa aren horrekin, zure izpirituaren erroilua eta berba santua idatzi dituzulako haren bihotzean, (...) eta horrek zure semeaz ernaldu du ene arima.. Horrenbestez, ontzat duzu ene arimari ziurtatzea zure semearen ama dela, zu zeu aita bakar zaituen semearena".

"I, Lord, I which am not worthy to ask bread, to come near the door of the right high place where Thy dwelling is! O what grace is this, that so suddenly Thou vouchafest to draw my soul in such highness that she feeleth herself the ruler of my body. She, poor, ignorant, and lame, doth find herself with Thee rich, wise, and strong, because Thou hast written in her heart the roll of Thy spirit and holy word, (...) which thing made her conceive Thy

\footnotetext{
h Bien suftiroit, saillant de tel danger. De me traiter ainsi qu' un estranger. Mais comme soeur mere (si dire l'ouse) Traitez mon ame, et ainsi comme espouse.
} 
son... Therefore dost Thou vouchsafe to assure her that she is mother of Thy son of whom Thou art the only father (118.orr.)."i

Erlazio espazioaren edo erlazioak gauzatzen diren espazioaren definizio berria poemaren lehen zatian hasi zen, Jainkoa bizi zen lekua aipatzearekin, gora, eta konparaturik arima bizi zen lekuarekin, behea. Kautan hartzekoa da ogibidea, eginkizuna, lantokia eta lekua antzeko kontzeptuak zirela; batek lanbidea zuen jaiotza lekua eta mailaren araberakoa, "egoera" bat zen. Gainera bizilekuak (dwelling-demeure) kasu honetan sunda edo kutsu maritalak edo ezkontzazkoak ere baditu. Horri erantsi behar zaio "Izpirituaren erroilua" arimaren bihotzean idaztea sexualki ulertu behar dela; gura horren hartze femeninoak (hau da, fedeak) Semea ernatzea ekarri zion. Goazen astiroago.

Zati horretan, esan genezake gizakiari buruzko kontzeptualizatukeran bi kontzeptu-sistema daudela elkar gurutzaturik. Bata gorputza/arima dikotomia platonikoa da, poema osoaren planteamenduak edo hari narratiboak dakarkigun bezala, bestea bibliatikoa da, gizaki eta Jainkoaren trebetasun kognitiboak hiru alderditan banatzen dituena: ulermena —bihotz-begiak, edo Aita_, komunikazioa — belarri-ahoak, edo Semea_, eta ekintza — eskua, oina, atzamarra, zakila... edo Gogo Zaindua- Malinak 1993an azaldu bezala (Ikus beherago). Elkar gurutzaketa hau Nahasketa Espazioan edo Bateraketa Espazio Mentalean agitzen da, Turnerrek eta Fauconnierrek 1994tik aurrera eman legez (ikus beherago). Jainkoaren kontzeptuak hiru kontzeptualizatze bide horiotatik - ulermena, komunikazioa eta ekintzaosagarriak bilduko ditu, alabaina Jainkoaren kontzeptua ez da horietako bakar bat ere. Pasarteak bi esparrutatik hartuko ditu osagarriak, bai esparru

\footnotetext{
i Moy, Monseigneur, moy, qui digne ne suis

Luc 15.

Pour demander du pain, approcher l'huis

Du treshault lieu où est votre demeure !

Et qu'est cecy? Tout soudain en ceste heure

Daigner tirer mon ame en tell' haultesse

Qu'elle se sent de mon corps la maistresse !

Elle povrette, ignorante. impotente, Philip. 4.

Se sent en vous riche. sage et puissante.

Pour luy avoir au coeur escrit le rolle

De vostre Esprit et sacrée Parole.

En luy donnant Foy pour la recevoir.

Qui luy a fait vostre filz concevoir ;

En le croyant homme. DIEU. Salvateur.

De fous pecheurs le vray restaurateur.

Parquoy daignez rasseurer qu'ell est Mere

De vostre filz, dont vous estes seul Pere.

Roma. 5.
} 
biblikotik eta bai esparru platonikotik, baina, berriro ere, era zehatz batera nahasturik dauzka esparruok, eta era hori ez da ez platonikoa ez biblikoa. Orain begiratuko diegu trinkoegi aipatu ditudan bi ardatzoi banan-banan, lehenago antropologiako ikarrari eta gero kognitiboari.

\subsubsection{Gizakiari buruzko irudia Biblian: organoetatik ahalmenetarako bide metaforikoa}

Malinak (1993) diosku gizakiaren eta munduaren arteko elkareragiketaren eremuaren mugak modu metaforikoan deskribatzen direla, giza gorputzaren atalen bidez. Bihotzaz pentsatzen dugu (cf. gaztelaniaz concordia, recordar, acuerdo, cuerdo, denek dute latineko cor =bihotza etimoa azpian) eta begiek informazioa ematen diote bihotzari; ahoa daukagu berba egiteko, eta belarriak besteen hizketa jasotzeko; oinak eta eskuak, berriz, gauzak egiteko. Modu abstraktuagoan, gizakiak ingurunearekin daukan elkareragiketa hiru eremutan banatzen da. Eremuok elkarren mugen barruan sar daitezke, baina ondo bereizten dira bata bestetik: alderdi emotibo-kognitiboa, adierazpen-diskurtsoaren alderdia, eta ekintza-helburuen alderdia. Biblian, gizakiek borrokan dihardute ingurune fisiko eta sozialean euren lekua lortzeko; borroka hori euren erreakzio barru-barrukoen arabera antzematen da (begi-bihotzen bidez), hizkuntzaren bidez adierazten (aho-belarriez) edota kanporako ekintza bihurtzen (oin-eskuez).

Malinak, Testamentu Berrian beste kasu interesgarri bat aurkitzen du. Oraingoan azpiko motiboa Jesusen esperientzia da, eta Jesusek Jainkoarekin daukan harremana. Jesusek Aita deitzen dio Jainkoari, hots, Ugazaba. Pasarte askotan ematen zaigu Aitak egiten duenaren berri, eta bertan ikusten dugu Aitak hiru eremu horiexen arabera betetzen dituela Jainko zereginak. Hala ere, zenbait pasartetan Jesus Aitarengandik bereizten zaigu, Seme den aldetik, eta halakoetan Aita begi-bihotzen eremu gisa azaltzen da. 37 Areago: Jainkoa den aldetik, Jesus, Seme gisa, Aitaren agerpidea da; Aitaren agertze hori aho-belarrien arabera deskribatzen zaigu, bete beharreko Hitza dugu. Alabaina, gizona den aldetik, Jesusek hiru alderdiak ageri ditu, edozein gizakiren moduan. Bestela esanda, Jainkoa den aldetik Aitaren ahoa da, eta hiru alderdiak dituenez gero, gizakia ere bada.

Azkenik, oin-eskuen alderdia Jainkoari aplikatzen zaionean Izpiritu Santuari dagokio beti-beti. "Spiritus" berbak haizea esan nahi du, antzinateko energia iturririk garrantzitsuena, giharren indarra alde batera utzita. Haize santuak jarduera, ekintza, eraginkortasuna adierazten du beti ("Jaunaren eskua eurengan zegoen IErregeak 18:46, etab. Jesusek Jainkoaren 
atzamarraren bidez egiten du ona, suzko mihiak hitz egitearen faktitiboa dira). Malinaren ustez garai hartako fisikaren arabera, haizeak, urak eta suak isurkien ezaugarriak zituzten. Beraz, Izpiritua isuri egin zitekeen, eta, hartara, gizakien ahalmenen hiru alderdietan zabaldu bere eragina, ez bakarrik oineskuetan. Laburbilduz, kristautasuneko Jainko Hirukoitzaren sustraiak hemen azaldutako kulturaren hiru alderdien ereduan daude. Nolabait esan, gizakiaren osaeraren modeloa Jainkoaren esperientziari aplikatzen zaio, eta, areago, Biblian azaltzen diren jainkozkotasunaren ideiek, oro har, gizakien gogo eraikuntzaren hiru alderdien ereduan dauzkate erroak, ${ }^{38}$

\subsubsection{Metafora kontzeptualetik bateraketa teoriara (Blending Theory)}

Lehen esan dudan bezala, linguistika kognitiboak metaforaren ikerketari ekin zion, ustez ezen horrela gizakiaren pentsatzeko mekanismoak idoroko zituela; hots, metaforek, batez ere eguneroko hizkuntzan ageri ohi ziren oinarriko metafora kontzeptualek, zerbait esaten ziguten gizakiaren gogoaz. Azterketa egiterako metodologikoki bi arlo edo eskupe ("domain") postulatzen ziren: sorburua eta xedea. Halan esan nezake "burtsa mariagora dabil"; metafora horretan iturria edo sorburua itsasoa da eta xedea burtsa; itsasoak gora egiten du sei ordurik behin, eta burtsako akzioek garestitu egiten dira honenbestero; garestitze hori garaiera bezala ulertzen dugu lehen ikusi dugunez korrelazio metafora delako (kantitatea altuera bezala ulertzea); gainera inplikazio batzuk ere badatoz sorburutik xedera, hots, burtsak isurkitasuna edo egonkortasunik gutxi izatea, edo behintzat akzioen balio gora eta behera ibiliko dela beti, eta holakoak. Horrez gain, nire hizketakideak are gehiago gara lezake metafora, urrats bat aurrera eta erantzun "bai baina zure diru ttanttak oraindik sikutan dituzu" eta horrela esaten dit nik karuagotan erosi nituela ditudan akzio apurrak eta oraindik ez dudala dirua berreskuratzeko garaia, eta abar. Aldiz, ezingo nuke ulertu egitura horretatik kanpo gera zitekeen beste edozein "metafora", adibidez, "bai baina txaparrada datorkizu eta ez dira mazopak gero", sorburu berari dagokion arren ez zaio egokitzen gertaeraren topologiari eta, hartara, ulertezina da. 


\begin{tabular}{|l|l|}
\hline Sorburua & Xedea \\
\hline Itsasoa & burtsa \\
\hline Ur ttanttak & akzioak \\
\hline Mariagora & Akzioen garestitzea \\
\hline Mariaren marra & Burtsako indizea \\
\hline
\end{tabular}

Metaforak aztertzeko eredu hau ondo zegoen sorburuko egitura eta topologiak ondo zetozenean bat xedeko topologiarekin, hots, egituraren proiekzio analogiazkora mugatzen zenean. Arazoa sorburuko arloko egitura eta xedekoa desberdinak zirenean zetorren baina, eta are metafora sorberriak bere eskuko egitura sortzen zuenean.

Aurreko ereduaren muga deskriptiboak erakutsi zituzten adibideetako batzuk hauexek izan ziren: "You are digging your own financial grave" (literalki "zeure finantza hilobia ari zara egiten") eta "this surgeon is a butcher" ("zirujau hori harakina da") ${ }^{39}$. Har dezagun azken adibidea; iturria harakina da eta xedea zirujaua eta esan nahi dugu zirujau hori oso baldarra dela eta "sarraskiak" egiten dituela. Baina berez harakina ez da bere lanean baldarra ez zantarra, fin fina izan daiteke. Orduan nondik datorkigu harakin bezala ezagututako zirujauaren baldartasunak eta abarrak? Berez sortzen den egitura batetik; eta non sortzen da egitura hori? Ba nahasketa espazioan. Espazio hauek erdiko espazio mentalak edo gogo espazioak deitu ziren Fauconnierren lanaren ildotik. Beraz, nahasketa espazioa edo bateraketa espazioa ("blending space") gogo-espazioa da, espazio horrek informazioa ekartzen du beste bi (behintzat) sarrera espazio mentaletatik, baina bere eskuko egitura kontzeptuala sortuko duelarik. Lehengo sorburu-xede terminoen ordez orain sarrera espazioak ditugu. Gainera laugarren gogo espazio bat ere izango dugu espazio orokorra edo generikoa deritzona.

Lehengo eskupe edo arlo (domain) terminoaren ordez orain gogoespazioa daukagu. Gogo espazioa lekuan lekuko ulermenerako eraikitako kontzeptu mataza txiki samarra da. Gogo espazioak pentsatukeran eta berba egikeran eraikiz daroatzagu; elkarri lotuta daude eta alda daitezke mintzaldia garatu ahala (Fauconnier, 1994 [1985]). Adibidez, diodanean "1991ko Larrunerakoa" gogo-espazioa sortu dut, eta gogo espazio horretan Larrunera joan ginen lagunak daude, erabili genuen beribila, hartu genuen disgustua goian teleferikoa ikustean, egin nuen komentarioa Lourdesko Pic du Jerri buruzkoa, data, lekua eta beste. Horrez gain, "ibilaldi" arlotik egitura partziala eskuratuko du, baina "ibilaldi" arloari lotutako ezagutzatik apur bat 
baino ez da gogo espaziora esplizituki jasoko, bestelako egitura gehigarria defektuz eta jardunbide pragmatikoen bitartez eskuratuko baita.

Espazio askoko ereduak sarrera espazio bi izateagaz sorburua eta xedearen ordez, metafora eta analogia baino haragoko mekanismo kontzeptualak ikertu ahal ditu, bestela esan, orokortasun maila handiago lortu du. Erdiko beste bi espazioak, esan dudan bezala hauexek dira: espazio orokorra edo generikoa, zeinek sarrera espazio biotan dagoen egituraren hezurdura dagoen, eta bateraketa espazioa, espazio aberatsa da eta beste sarrera espazioetatik integratzen du aldi baterako egitura zehatza eta lokala. Espazio honek beste bi espazioetatik proiektatu ez den egitura berria sortzen du sarri. ${ }^{40}$

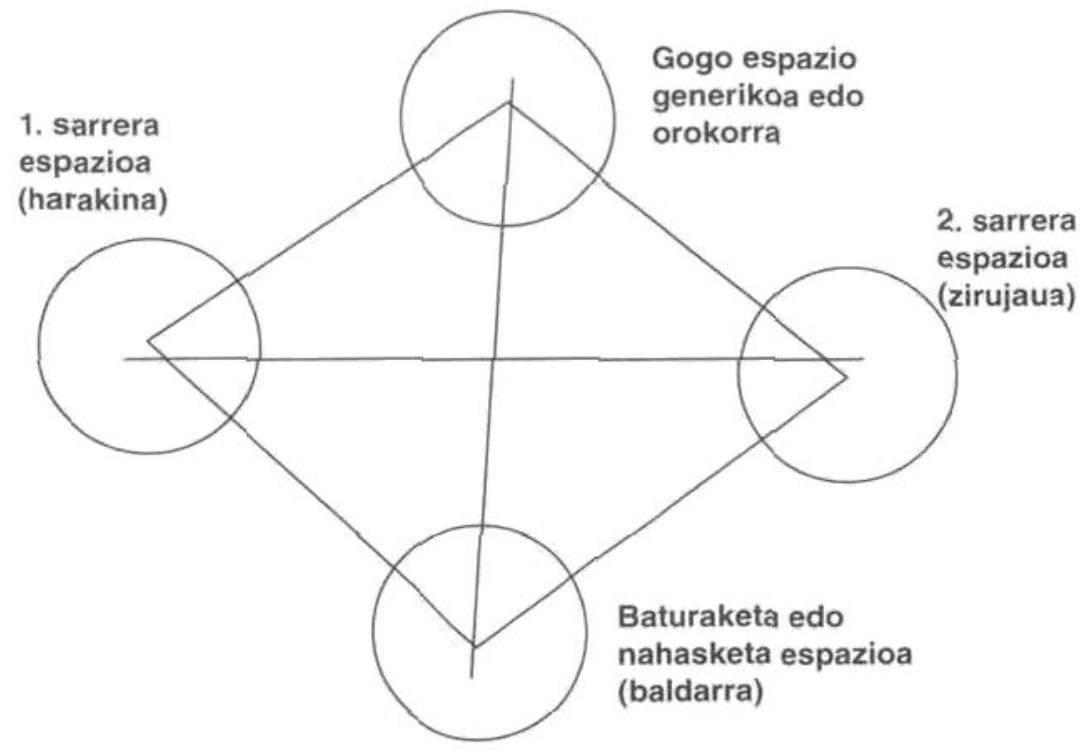

\subsubsection{Margaritaren estrategia orokorra}

Alde antropologikoa ikusita eta metodologia kognitiboa geureganaturik, itzul gaitezen gure testukira. Alde batetik autoreak zabaltzen du arlo edo eskupe biblikoa zenturioiari egindako aipuarekin ("ogia eskatzeko on ez naizena"). Esparru biblikoa informazio iturrietako bat izango da, hau da, sarrera espazio bat. Jainkoa xedean edo bigarren sarrera espazioan Jesusi dagokio lehen espazioan edo sorburuan, hala ere, konturatu gaitezen lehen sarrera espazioan zenturioia eta zenturioiaren semea dauzkagun bitartean xedean arima baino ez daukagula, eta egokitze edo kidetze lanak penazak izango ditugula: 


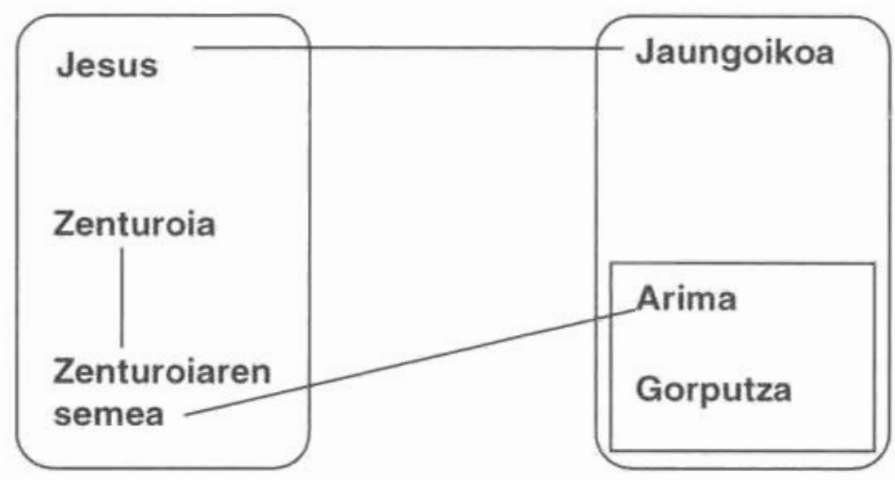

Ohar bedi irakurlea berez Bibliako bertako idazleak emana digula oso metafora landua: lehenbizi zenturioiak seme gaixoaren ordez hitz egingo zuen, baina eskaera bukatzen dueneko bere buruaz ari dela dirudi: "'Jauna ni ez naiz nor zu nire etxera sartzeko baina esazu hitz bat eta osatuko naiz" (ez zen ba semea gaixorik zegoena?). Berez, ondinokarrenean ere, kideketa ez dut bere konplexutasun osoan eman, zeren guk testuan irakurri duguna "ogia hartzeko ere ona ez naizena" izan denez, eta horrek bultzatu baikaitu lehenago inguru liturgikoa imajinatzera, errito teofagikoa alegia, eta hortik gero esparru biblikora.

\begin{tabular}{|l|l|l|}
\hline Jesus & Ogia & Jainkoa \\
\hline Zenturioi-semeak & Gorputzaren barruan legokeen arima & Arima kontalaria \\
\hline Etxea & Gorputza & \\
\hline Etxeko atea & Ahoa & \\
\hline
\end{tabular}

Gure kulturan bai bekatua eta bai gaixotasuna zikina bezala ulertzen dira; oinarriko metafora kontzeptual hori daukagulako badakigu "gaixorik" dagoena arima dela, eta beraz kideketa zenturioiaren semea eta arimaren artean ezarri behar dugula. Semea arima baldin bada, semea dagoen etxea zerekin identifikatu eta gorputzarekin. Katolikoen erritoetan komekatzeko orduan esaten dira berbok, ahoa etxeko atearekin identifikatuz eta abar. Zenturioiak bere burua semearekin identifikatzean, eta behin gure gogoan semea arimarekin bateratuta, berehala konturatzen gara zenturioia eta etxea gauza bere direla, hots, gorputza; zenturioiaren semea eta aita identifikatuz zenturioia eta etxearen arteko metonimiazko lotura lantzen dugu; esateko, metonimia batek bestea dakar. Hau guztia testu biblikoan bertan emana zaigu, behin testua katolikoen inguru teofagikoan kokatuz gero. Hartara, 
kontzeptuok bateraturik edo integraturik datoz testuan integrazioa bigarren aldiz gertatzen denerako, hau da, testuko hariarekin bat egiten dugunerako.

Testuaren haria ez da eteten esparru biblikotik esparru platonikora igaro doanean, gorputzaren eta arimaren arteko desberdintasuna jakintzat ematen duenean. Hori da aurretik irakurleak zabaldurik duelako arimaJainkoaren gogo espazioa, irakurlea saiatu baita Bibliako pasartea ordura arteko istorioarekin batera ekartzen. Beraz, ez da bestelako ahalegin kontzienterik egin behar, baina ohar gaitezen esparru hori prest daukagula (eta idazleak badaki) behar dugun informazioa hortik eskuratzeko. Idazleak egiten duena oso sinplea da: hierarkiaz dugun ulermena esplotatuko du. Mendetasun ez uniformearen kontzeptua ulertu eta azaltzeko mailaketaren irudia erabili ohi dugu. Altuera boterearen hedadurarekin parekatzen da. Beraz, zenbat eta garaiago izan belauna edo maila halan eta botere boteretsuagoa. Halan da ze arima Jainkoak beregana daramanez, oso leku garaira doala, eta leku altu horrek botere handia ematen diola (eta honez, gorputzaren "gainetik jarri da" edo nagusitu zaio).

Konturatu gaitezen zati honek zuen garrantzia ideologikoa zenbaterainokoa den, eta zein erraz lortu duen idazleak. Guk orain arte daukagun irudia buruan komekatzeko ordua da, hor sinestedunari objektu bat ematen zaio jateko, zelanbait Jesus zenturioiaren etxera doala; gorputza arimaren ontzia bezala ikusten denez (eta arima isurki bezala), arimara heltzeko, esateko, ontzi horren barrura heltzeko ahotik sartu behar. Margaritaren testuan irudi horren gainetik egingo dugu jauzi, trukaketarako objektua grazia bera baita ogi sinbolikoaren ordez, horretara arima-isurki hori Jainkoarengana eroana dela. Berba batean, sakramentuen ordez hausnarketa proposatzen zen.

Hurren zatirik polisemikoena dator, graziaren oparia zertan datzan azalduko baitzaigu. "Graziaz" ari dela badakigu kausalaren marka ikusi dugulako. Hizkuntzazko marka bat antzemateak badu bere garrantzirik teoria honetan: hizkuntza markak espazio mentalak zabaltzeko lorratzak bezala hartzen ditu Fauconnierrek, beraz hizkuntza hartzaileak esangura eraiki dezan aztarrenak dira. Kausalaren marka hori irakurtzean atzeko espazio batera, edo denboran aurretik agitu den gertaeraren batera itzuli behar izan dugulako, nolabait esan, kausa ematen bazaigu lehenagotik eman zaiguna ondorioa izango zen (leku garaira heldu izana alegia). Grazia honetan zetzan: arimaren bihotzean izpirituaren erroilua eta berba santua idatzi da. Jainkoaz lehen esan dudanak berdin balio du gizakiarengan bihotzak duen funtzioa ikusteko: ulermenaren eta nahiaren egonlekua. Bestetara esan: arimaren nahian borondate bat idatzi da. Idazteak badu zerikusirik denboran zehar 
irautearekin, idazten denak hantxe dirau, bihotzean idazten bada, hots, oso sakon, oso sendo idatzita egon beharko da (konturatu gaitezen kausa-ondorio inbertsioaz hemen, "You are digging your own grave" kasuan bezalakoa). Idaztea eskribauen eta baratarien kontua da, eta idazten dituzten gauzetako bat testamentuak edo hilburukoak dira. Idatzia, noski, Hitza da, hots, Eskriturak (testamentua, hilburukoa, ituna, etab). Hauxe berori ari ziren erreformistak errebindikatzen: eskriturei libreki hurreratu ahal izatea. Hitz hori Jainkoaren borondatea bada, eta borondate hori neure borondatean idatzita baldin badut, neure nahia eta harena bat izango dira, eta hori izan behar da komekatzeko modua. Honez gain, Semea ernaltzea dago; pentsa dezagun bide batetik hizkuntza erromantzeetan "conceptiok" dituen bi esangurak, biologikoa eta intelektuala. Esparru biblikoan biek bat egiten dute, hitzak ordain gorpuztua ere baduelako. Intelektualki "kontzebitzeak" sexualki ernaltzearekin identifikatuko da, eta hortaz idazleak xedean demostratuko du nola arima Jesusen ama den. Hori berez "double scope integration" da ${ }^{41}$ : isuri bikoitzeko bateraketa, bestelako bateraketa bezalakoa da, baina abantailetako bat zera da, behin bateratze espazioa sortu ezkero ere, itzul gaitezkeela sarrera espazioetako edozeinetara berriro ere, baina orain bateraketa espaziotik informazio eta egituraketa berria eskuratuta. Eta hementxe utziko dut pasarte honen azterketa.

Pasarte horren azterketak balio izan digu Margaritaren estrategia orokor bat diseinatzeko.

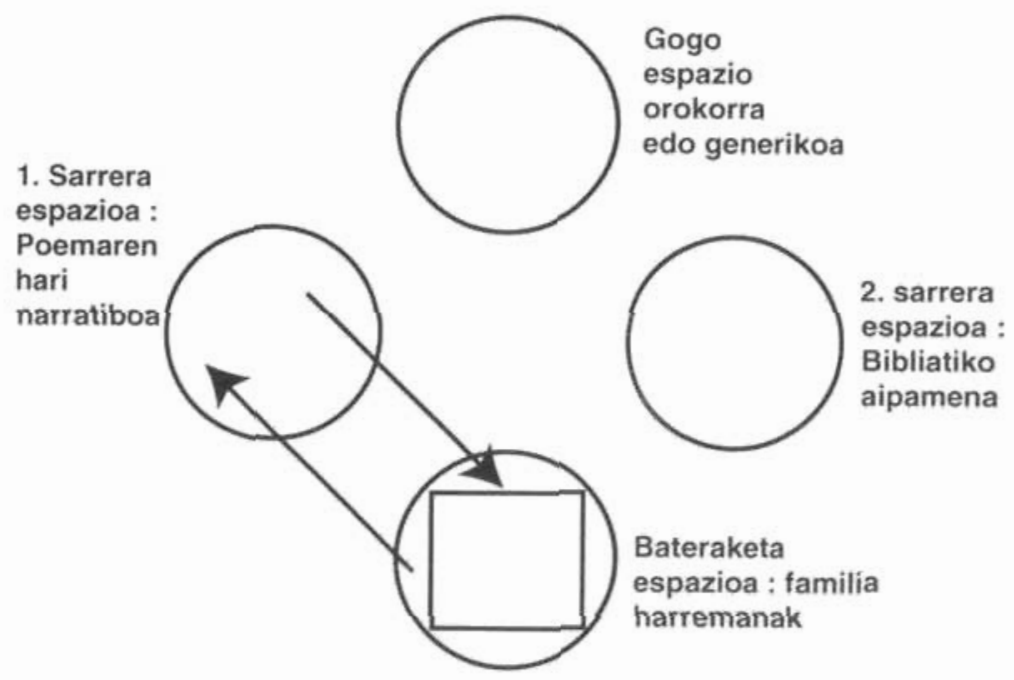

Arin esatera, Margaritak Bibliako aipamena eta bere poemaren haria sendiaren barruko harremanen arabera interpretatuko ditu biak. Beraz, 
Bibliako harremana familiartekotzat jo daiteke, eta hortik bere haria ere, hots arima-Jainkoa ere familia harreman gisa har daiteke. Horrela demostraturik uzten du berari interesatzen zaion azken hau: Jainkoa eta arima ahaideak direna alegia. Familia harremanak ez datoz inongo espaziotatik, baina irakurleok oso ezagunak ditugunez erraz eraiki genitzake nahasketa edo bateraketa espazioan bertan; gainera, gauzak errazteko, normalean Bibliatiko aipamenean badago familiarteko harremanen bat egotez.

Kontaerari nagokiolarik, esan beharra dago, arimak nozitu duen Jainkoaren manipulazioaren bitartez, aldaketa ontologikoa gertatu dela, eta orain Jortu duela arimak Jainkoarekin ezkontzeko beharrezkoa zuen gorengo maila.

\subsubsection{Arima Jesus-Jainkoaren Ama da}

Jainkoak bere ariman idazten duen legez, eta Izpiritua hartzeko fedea eman dionez, arima Jesusen ama bilakatu da, baina, denarekin ere, Aitaren alaba sortzez. Eskura dauden metafora esparruetatik informazioa jadesteaz gain, edota hipotestu biblikoetatik eszena berriak iradokitzeko, Margaritak autoritate biblikoa erruz darabil proba gisa (AUCTORITAS). Antzinako erretorika liburuetan bi eratako probak bereizten ziren, artistikoak edo arteaz sortuak eta artetik kanpokoak edo sortu gabeak. Norbaiten lekukotasuna, jainkoena barne edo "apostrofa", erretorikatik kanpo zegoen hau da, ez zen arteaz sortua. Gogora ekar dezagun lehen azaldu dudan bezala Margaritak bere burua erretorikarik ez zekien emakume ezjakin gisa aurkeztu digula, eta gainera San Augustinek gomendatzen zuela elokuentzia edo etorri eskaseko hizlarientzat eskritura buruz ikasi eta bertatik erabiltzea hizkera (zeina baitzen egon zitekeenik eta egokiena). Honez, etorriaren ordez memoria behar dugu, baina memoria erudizioa da, eta Margaritak erudizio itzela erakuste digu.

Hemen, esatea legez, aipu bat bestearen barruan ageri digu: "Nire aitaren nahia egiten duena, hura da nire anaia eta arreba, eta ama” Mateo 12.

\section{"Those that shall do the will of My father, they are My brethren and mother."j}

Argudioa bat dator lehen emanikoagaz, Jainkoaren nahia edo ituna (testamentuak edo hilburukoak gizakiak familia bilakatzen baititu. Nahia

\footnotetext{
j Quand en preschant, estendant voz bras, distes :

Ceux qui feront le vouloir de mon Pere, Matth. 12.

Mes freres sont, et ma soeur, et ma mere.
} 
bietara ulertu behar da, ondasunak ondorenei partitzen dizkien hilburuko testu gisa, eta borondate gisa, borondateak dituen direkzionaltasun edo zuzenbide guztiekin. ${ }^{42}$

Arima Jainkoaren amaren izena (eta egoera) erabiltzen ari denez, errespetua erakutsi behar dio etxeko Amari, Mariari, alegia. Malina antropologoak argitaratu zuen bezala, Europako gizarte diadikoan emakumeak semeaz erditzearekin eskuratuko zuen etxean boterea, bestela senarraren amaren pean bizi beharko zen. Behin gizonezko batez erdituz gero hierarkia azpikoz gora jarriko zen. ${ }^{43}$ Uste dut testuinguru honetan ezarri behar dugula Mariari egiten dion (azken) gorazarrea: Maria arimaren senarraren ama da, baina arima Semeaz erditu denez, arima Mariaren dinakoa izango da aurrerantzean. Andre Maria Jesusen ama da gorputzez eta arimaz, baina hartuak ditu ohore handienak, Jainkoak bera emanak: "Inongo gizonek eman uste izango balizu Jainkoak berak baino gorazarre handiagokorik, blasfemia litzateke":

"...if any man should think to give thee greater praise than God Himself hath done, it were a blasphemy (120)."k

Hauxe dugu testuko pasarterik ardatzena. Areago, usteak ematen dit hauxe dela testuaren benetako helburua: Mariaren irudia doktrinetatik ezabatzea, sinesmena sineskerietatik garbitzearren. Suposatu genezakeenez Mariak lekuan lekuko izena hartzeari paganismoaren sunda igarriko zioten erreformazaleek, izen horren aniztasunaren azpian legokeen politeismoagatik edo animismoagatik. Gainera Maria artekarien paradigma da, eta erreformazaleek kristautasun zuzenagoa nahi zuten.

Arima Jesusen arreba eta anaia da

Semeak gure hautsekin bat egin duenez — berez, Aitak gugandik hain gertura jarri duenez - : "deituko diogu gure ahizpa eta neba"

"...then do we call Him sister and brother (p. 118)."1

\footnotetext{
$k$ De cuyder mieux vous louer, $c^{`}$ est blaspheme.

II n'est louenge telle que de DIEU mesme.

${ }^{1}$ Quand vostre filz plein de divinité

A prins le corps de nostre humanité Philip. 2.

Et s'est meslé avecques nostre cendre :

$\mathrm{Ce}$ que sans Foy nul ne pourroit entendre,

II vous a pleu de nous tant l'approcher

Qu'il s'est uny avecques nostre chair:

Qui le voyant (comme soy) nommé homme.

Se dit sa Soeur, et Frere elle le nomme.

Bien doit avoir le coeur ferme et asseur

Qui de son DIEU se peult dire la Soeur.
} 
Hortaz, arima Jesusen ama izateaz gain, bere arreba ere bada: "orain bada, arimak (zeinek Jainkoaren arreba dei bailiezaioke bere buruari) beharko du...".

"Now, the soul (which may say of herself that she is the sister of God) ought...."

Eta familia unibertsala ahotan hartuta, Aita bakarra daukagula eta, arimak (Jesus) Jainkoari "neba" esango dio. Indartzeko argudioa Salomonen Abestitik edo Kantuen kantatik ekarriko du aipu biblikoa 44: "Ez dut zuri neba deitzeko lotsarik edukiko, zeren Salomonen bidez bere baladan esan baituzu, esanez, arreba neurea, zure begietako baten eta zure ileetako baten begiratu gozoaz zauritu didazu bihotza":

"...I will not fear to call Thee my brother, for so hast Thou said by Solomon in his ballad, saying, My sister, thou hast wounded my heart with the sweet look of one of thy eyes and with one of thy hairs." $m$

Jesusi ahizpa eta neba deitzea agian izan daiteke gorputza eta arimaren generoaz diharduelako, baina ez dut erantzun errazik.

Arima Jainkoaren alaba da

"Honen ostean maitasun handiz adierazten duzu nola haren sortzea ez den besterik harengana beti izan plazer duzun onginahia baino, eta ziurtatzen duzu (bera zaindu zenuen) lehen eguna baino lehenagotik berarengan izan duzula zure maitasuna, eta zelan (maitasunaren bidez) zeuk sortu duzun, zeuk (bakarrik) oso ondo egin dezakezun moduan (...) Orduan egiak sentiarazten dio benetako aitatasuna dela zugan".

"After this dost Thou declare with great love how her creation is only the good will which it pleaseth Thee to have always toward her, giving assurance that before her first day (providing for her) Thou hast had Thy love in her, and how (through love) Thou hast begotten her, as (alone) Thou canst

\footnotetext{
$\mathrm{m}$ Je ne craindray de vous nommer mon frere.

Vous lavez dit en lieu bien autentique,

Par Salomon, en vostre doux cantique

Disant: «Ma soeur, tu as navré mon coeur. $\quad$ Cantique 4.

Ta as navré mon coeur par la douceur

$D^{*}$ un de tes yeux et d'un de tes cheveux.m

Testu aldakiak badira itzulpenean, segurutik Biblia diferenteak erabili diren seinale. 1548an argitaratutakoak halaxe dio: Well than, seynge that we have both but one father. I wyll not feare to call the my brother. For so hast thu reported it by Salomon in hys bellet.saynge. My syster and spouse thu hast wounded my harte with the swete loke of one of thyne eyes, and with one cheyne of thy necke.
} 
do very well. (...) Then the truth maketh her to feel that there is true paternity in Thee." $n$

Jainkoaren aitatasuna, honetaz, bere arimagazko jokaeran datza, bere isuri maitekorrean, eta areago, arimari gorputza eman dionez gero, izate fisikoa eman ere. Margaritak darabiltzan familia metafora guztietarik honixe irizten diot nik ilunena, segurutik metaforarik onartuena delako. Gogoan erabil dezagun gizakiok kausazioa sorrera bezala metaforizatu ohi dugula; hots, sorburua gerokoaren kausa dela uste dugu, eta, honen harian, egon zela joera bat hamaseigarren mendeko Europako herrialde batzuetan erregea ia-ia kausa bezala ez bazen behintzat aginte printzipio bezala ikustekoa.

Jainkoa kausa bada, eta kasua jatorria bezala ulertzen badugu, orduan Aita izan behar du, hots, jatorria eta kausa. LEHENA KAUSA DA oinarriko metafora proposatu daiteke, kausatzea termino sortzaileetan ulertzen dugula azalduko ligukeena. Erraz jartze aldera, esan dezagun zerrenda tenporala maila abstraktuagora metaforizatzen dela, eta beraz lehen gertaera bigarrenaren kausatzat hartzen dugula. Kausazioa horrela harturik kausazio erretorikoa edo hizketaldikoa da, non kausa baldintza nahikoa den baina ez ezinbestekoa, geometrian gertatu denaren kontrara. Adibidez, "Hiri bi horiek ahizpa bizkiak dituzu trafikoari dagokionez", esaldian familia erlazioek kausaren arabera aterako dute esangura. Erabil ditzagun gogoan hurrengo predikazioak, "ama berekoak", "aita bat dute", "lehengusuak dira", "ez du ematen ama bera dutenik ere", etab. ${ }^{45}$ Hala ere, testuki honek diosku aitatasuna maitasunean datzala, arrazoiketaren pisu guztia Jainkoak duen arimarekiko jokaeran datza, bere borondate ona arimarentzako. Honek oparien trukaketarantz abiatuko gaitu, oparia maitasunaren seinale bezala.

Geroago arimak "aita" deituko dio Jainkoari (119orr.), bi aldeko argudio bat gehituta: Aita Gurearen bidez biei egiten die aipu: Eskrituren autoritateari eta familia unibertsalari. Bestalde, autoreak "alaba" hitza jartzen du Jainkoaren ahoan berari deitzeko, berriz ere Eskrituren autoritatera joaz (Prov. 23). Eta atzera ere, "Helas, nire aita zaharraren leinua hautsi baituzu, zalantza barik, alaba ordeko deitu didazunean (121)"

\footnotetext{
"Apres. venez par grand" dilection

Luy declarer que sa creation

N'est seulement que par le bon vouloir

Qu'il vous a pleu tousjours à elle avoir,

En l'asseurant qu'avant son premier jour, Ephe. I.

La prevoyant, y avez eu amour.
}

Par celle amour engendrée l'avez.

Comme vous seul bien faire le sçavez : 
"Alas, yea, for Thou hast broken the kindred of my old father, calling me daughter of adoption (121)."o

Ezkontzak, etxe aldaketak, etxe berriko ugazaba jauna aitatzat hartzea dakar, emakumeei inongo jabegorik izatea eragozten zien legeriaren arabera. Erromatarren Deminutiori dago lotuta: behin ezkonduz gero, emakumeek bi aukera zituzten, aitaren abizena eraman ala senarrarena. Aitarena eramatea erabakitzen bazuten, dibortziatu ahal izango ziren (hots, aitarenera bueltatu), baina, senarra hilez geroz, ezin izango zuten senarraren etxepartetik gozamenik izan. Senarraren abizena eramatea erabakitzen bazuten, gauza bera gertatuko zitzaien aitarekin, zelanbait esan, legez euren senarren alaba bilakatuko ziren.

\subsubsection{Arima Jainkoaren emaztea da}

Urrats honetan argudioak erreferentzia egingo dio ezkontzaren inguruko lege jokabide bati, alegia, ezkontza kontratuaren agerkari moduan senaremaztegaiek egin ohi zuten opari trukaketari. ${ }^{46}$ Jainkoak arimari agindu dio haren egoera hobetuko duela, eta agindu horrek berekin dakar Jainkoak arima emazte hartzea. Arimaren dotea, berriz, haren bekatuak izango dira. Hortaz, Adanen alaba izanda, Jainkoaren emaztea izan daiteke, eta bere egoera soziala hobetu. "Ontzat izan duzu arimari beste izen bat ematea, eta emazte deitzea, eta hark zuri senarra deitzea, eta adierazi duzu nola askatasunez ezkondu zaren berarekin. Bataioaren bidez zure ondasun eta aberastasunak berari ematea agindu duzu. Hartu haren bekatuak, ez baitu hori baino, Adan bere aitak eman zizkionak".

"It pleaseth Thee to give her another name, to call her Thy wife and she to call Thee husband, declaring how Thou hast freely declared the marriage of her. By the baptism Thou hast made a promise to give her Thy goods and riches. Thou dost take her sins, for she hath nothing else, which Adam her father did give her." $p$

\footnotetext{
${ }^{\circ}$ Helas ! ouy, car du pere maudit Avez rompu la filiation En me nommant fille d'adoption.

P II vous plaist bien luy donner autre nom Vostre Espouse la nommer, et de vous. Vous appeller son mary et espoux : Luy declarant comme de franc courage Avez juré d'elle le mariage. Fait luy avez au Baptesme promesse De luy donner vostre bien et richesse. Ses maux prenez, car riens que peché n' ha. Lequel Adam son pere lui donna.
} Osee. 2. 
Arima Jainkoaren emaztea da Kantuen Kantari errenazimenduan ematen zitzaion interpretazioa dela bide 47 :"Eta, antzera, deituidazu emazte, eta erakutsi maite nauzula, eta (benetako maitasun arduratsuaz) esadazu honela: Ene usoa, jaiki zaitez, ene emaztea".

"And likewise Thou dost call me wife, showing that Thou lovest me, and call me (by true jealous love), My dove, rise up my spouse."

\subsection{Sendiarekikoak: arimagandik Jainkoagana}

Arima lau bider segurtaturiko lekuan dago "kokatuta", baina arimak familiako lau posizio horietan Jainkoarengana erakusten duen jarrerak kolokan jarriko ditu leku horiek:

\subsubsection{Arima umea eta Jainkoa aita}

Margaritak seme galduaren parabola dakarkigu oraingoan. Parabola horretan etxe bateko semeak etxe-partea eskatzen dio aitari eta badoa handik. Diru guztia gastatu eta gero, denik eta lanik umilena hartzea besterik ez zaio geratzen: txerriak zaintzea. Bere egoeraz gogoeta eginda, etxera itzultzea erabakitzen du, baina morroi, ez seme. Hala ere, aitak ohore eta festa handiez hartzen du berriro. Parabola horretan bezala, gure testuan ere arimak huts egin dio Jainkoari: "Eta irain egin dizudala ume galduak egin zuen legez, haragiaren salerosketa ergelari jarraika".

"Also that I have offended Thee as the prodigal child did, following the foolish trade of the flesh." $\mathrm{r}$

Hemen generoaren egokitze interesgarria daukagu. Hasieran, Margaritak generoa zehaztu barik aipatzen du Bibliako pertsonaia, "semea" esan beharrean "umea" esanez. Gero ume horren bekatuak "haragiaren sale-

\footnotetext{
9 Pareillement espouse me clamez

En ce lieu là. monstrant que vous m'aymez.

Et $\mathrm{m}$ 'appellez, par vraye amour jalouse.

Vostre Colombe, et aussi vostre Espouse.

Cantique 2.

'r Donc, à mon Pere ! où gist amour non feinte, Jaques 3.

De quoy fault il qu'en mon coeur j'aye crainte?

Je recongnois avoir fait tous les maux

Que faire on peult ; et que rien je ne vaux.

Et que vous ay, comme l'enfant prodigue.

Abandonné, suyvant la folle ligue,

Où despendu $\mathrm{j}$ ay toute ma substance.

Et tous voz biens receuz en abondance :
} 
rosketa" anbiguoaren bidez deskribatzen ditu. Hori bi modutara uler daiteke, "salerosketa" hitza segun eta zelan ulertzen dugun: edo prostitutaren sexu harreman ordainduak direla pentsatuz edo, bestela, modu orokorragoan, merkatari munduzalearen negozioak.

Alabaina, parabolan bezala, aitak ez du bere umearen bekatua ikusiko. Hori garrantzitsua da bai estasi legalaren ikuspegitik arlo politikoan (aitaren jarrera) eta bai aitortzaren sakramentuaren arbuiapenaren aldetik, arlo erlijiosoan: "Non da, orduan, ni zigortuko nauenik, neure aitak ene bekatua ukatzen dionean? Ez dago inongo gizona kondena dezakeen epailerik, baldin eta Jainkoak berak gizon hori gaitzesten ez badu. Ez naiz ondasunik ez izatearen beldur, Jainkoa dut-eta aita".

"Where is he then that shall punish me when my father shall deny him my sin? There is no judge that can condemn any man, untess God himself would damn him. I fear not to have lack of goods since I have God for my father."s

Berriz ere, bertikala da erlazioa: ez dago bitartekaririk, ez abokatu eta ez abaderik.

\subsubsection{Arima, Jainkoaren ama}

Familia harreman hau poemaren bigarren zatiko kontzepturik landuenetako bat zenez, hirugarren zati honetan ere testuak zenbait gogoeta interesgarri eskainiko dizkigu arima eta gorputzaren arteko harremanez. Lehenago esan dudanez, arima manipulatuz, arima eskutan erabiliz, Jainkoak leku berria ematen dio. Ukitze horrek arimari dakarkion lehendabiziko aldaketa gorputzaren gainetik jartzea da (gorago aipu batean ikusi dugunez). Arimak ezin du esan Jainkoaren alboan dagoenik, baina Jainkoaren ekintzaren bidez gorputzaren jabe sentituko da. Garrantzitsua da gogoratzea frantsesez arima femeninoa dela, eta gorputza, berriz, maskulinoa. Elizabethen itzulpenak ez du gorputz maskulinoan aurkezten, baina argi eta garbi azpimarratzen du arimaren femeninotasuna.

\footnotetext{
${ }^{S}$ En lieu d'avoir par vous punition.

Vous $\mathrm{m}$ 'asseurez de ma salvation.

Ou est celuy done qui me purnira

Quand mon peché mon Dieu luy niera?

Juge n'est point qui puisse condemner

Nul, puis que DIEU ne le veult point damner.

Doute je n'ay d'avoir faute de biens.

Puis que Mon DIEU pour mon Pere je tiens.
} 
Arima eta gorputzaren arteko erlazioen beste alde interesgarri bat zera da, berriz ere sexu harreman (debekatu)en bidez sinbolizatuta datozela. Jainkoak gorputzaren barruan jarri du arima: "ez nagiaz lokartzeko, baizik eta batak eta besteak beste lanik izan ez dezaten zeu zelan zerbitzatu pentsatzea baino"

"not for sleep with sloth but that both of them should have no other exercise but only to think how to do some service unto Thee (118)."'

Aipu honek egoeraren konnotazio sexualak argiro ispilatzen ez baditu ere, poemaren bukaeran autoreak modu esplizituagoan adieraziko du (ikus beherago, heriotzaren beldurra dela eta). Garrantzitsua arima eta gorputzaren arteko harremanen norabidea da, hots, batak bestearekiko vs biek Jainkoagana. Ziur aski sexua edo maitasuna erlazio prototipikotzat har dezakegu. Beraz, kide biek, arimak eta gorputzak, Jainkoa zaintzea izango dute eginbehar, printze baten zaindariak balira bezala.

Baina orduan arimak huts egingo du eginbehar horretan: "Izan ere, zutaz ernaldu eta erditu ondoren, arrazoimena utzi nuen albo batera; eta neure botondatearen menpeko bihurturik, eta zuri jaramonik egin gabe, lo geratu nintzen eta lekua utzi nion nire etsai handiari: ezjakintasunaren gauean (lo bainengoen) nigandik ostu zintuen, maltzurkeriaz, eta zure lekuan bere ume hila utzi zidan. (...) Nire etsaiak, nire sentsualitateak (ni piztikeriazko to zorroan nengoela) neugandik ostu zintuen, eta beste ume bat eman zidan, bere baitan bizirik ez zuena, eta bekatua deritzona”.

"For after I have conceived and brought Thee forth, I left reason; and taking subject unto my own will, not taking heed unto Thee, I fell asleep and gave place to my great enemy: the which in the night of ignorance (I being asleep) did steal Thee from me, craftily, and in the place she did put her child which was dead. (...) My enemy, my sensuality (I being in my beastly sleep)

\footnotetext{
${ }^{t}$ Et puis apres dens ce corps l'avez mise. Non pour dormir. ne pour estre remise. Mais pour tous deux n'avoir autre exercice Que de penser à vous faire service :
} 
did steal Thee from me and gave me another child having no life in him. which is called sin...(p. 123)."u

Alde batetik, ama bi ditugu: arima, hots, benetako ama, eta sentsualitatea, ama gaiztoa. Bestetik, lo geratu eta arrazoimena bazter uztea bekatua izan da, eta umea galtzea horren ondorioa. Honen atzean dagoen dikotomia honako hau da: arima = arrazoimena vs. gorputza=animalia. Piztiazaletasunaren edo bestialitatearen aipamenak interpretazio sexualera bultzatzen gaitu. Arimaren arrazoimena eginbeharrak betetzearen aldeko indar nagusia izan beharko zen (gogoratu Platonen irudian arima zaldi bik tiratutako karroza zela). ${ }^{48}$ Alabaina, arima — hau da, agintaria - lo geratuz gero, parte arrazoiduna desagertu egiten da. Ustez maitasunak bi alde ditu, fisikoa eta espirituala. Seme ttipia maitasunarekin identifikatzen badugu, gorputza, berriz, maitasun fisikoarekin, eta maitasun espirituala kontalariarekin, harreman batean alde espirituala lo geratzen denean horren emaitza maitasun fisiko hutsa izango da. Hortik dator kontalariak sentsualitate deitzea arrazoimena edo alde espirituala lo geratuz gero geratzen denari ("ma voisine," "my enemy."), 49

Lehenago esan dudanez, sexuak harreman prototipikoa irudikatzen du. Erlazioa bektore bat da, eta badu sorlekua, norabidea eta zentzua. Desira eta intentzio konnotazio nabarmenak direla medio, arima lo geratzeak gorputzarekin erlazio sexualak izatea esan nahi du, eta hortik sentsualitate etsai/auzokidea etortzea.

Ama bien arteko epaiketa Salomon epailearen eta ama bien pasarte biblikoa gogora ekarriz konpontzen da. Seme-Jesus honek, bestalde, badu aztertu beharreko korolario edo atxiki bat. Semea Elizarekin jdentifikatzen

\footnotetext{
"Car vous ayant conceu et enfanté, Laissant raison subjette à volunté, Sans vous garder, je me suis endormie. 3. des Roys.

Et donné lieu à ma grande ennemie.

Qui en la nuict d'ignorance, en dormant.

Vous a robbé pres de moy : finement

En vostre lieu m'a mis le sien tout mort. (...)

Ma voisine, má sensualité

En mon dormir de bestialité

Privée m’a de vous par son envie,

En me donnant un autre enfant sans vie.

Qui est Peché. duquel je ne veux point.
}

1548ko edizioak "Ma voisine" mantentzen du: Sensualyte my neyghbour ( 1 beynge in my beastly sleape) ded steale the from me, \& gave me, an other chylde whych had no lyfe in hym, named synne, whom I wyll not have, for i do utteriy forsake hym. 
badugu gorputzaren metaforaren bidez, ama egiazkoak hartutako erabakiak ispilatuko luke hamaseigarren mendeko Frantziako lehen erreformatzaile intelektualek Eliza Katolikoaren aurrean hartutako jarrera, hau da, Eliza Katolikoaren "irrazionaltasuna" kolokan jartzea, baina zatiketa saihestuz. Nolabait esan, nahiago zuten amaizunari (sentsualitatea=imajinak?) benetako semearekin geratzen utzi, Seme-Eliza zatikatua ikusi baino. 50

\subsubsection{Arima, Jainkoaren arreba}

Arima nebaren kontra altxatzen da. Hemen gogoratzen den Bibliako pasartea 12 Zenbakiak da, Maria eta Aaron Moisesen kontra mintzatu zirenean hura arrotz batekin ezkontzeagatik, debekatua baitzegoen halakorik egitea. Kontalaria - arima - Aaronen emazte Mariarekin identifikatzen da. Bibliako pasartean Maria eta Aaron kexu dira, esanez Jainkoak eurei ere hitz egin ziela. Beraz, itxura batean auzia apurtutako legeren bati zor bazaio ere, azpian bada legearen jabe nor den esateko norgehiagoka, Jainkoaren borondatea interpretatzeko lehia. Jainkoak erantzuten du, eta erakusten Moisesekin daukan harremana eta beste profeta batzuekin daukana arras desberdinak direla: besteengandik ostentzen bada ere, Moisesi aurrez aurre mintzo baitzaio.

Pasarte honetan arazoa interpretazioaren zuzentasuna da, hots, noraino daukagun Jainkoaren hitzaren ezaguera zuzena. Jakina, korolario erlijiosoa inspirazioaren jabegoaren arazoa da, eta interpretatzeko autoritatearena. Dakigunez, Moisesek Egiptoko faraoiarekin berba egiten ez joateko emandako aitzakietako bat zera izan zen, bera, Moises, hiztun ona ez izatea. Jainkoak esan zion Aaron anaia eramateko bere ordezkari gisa. Gaia gehiago elaboratuz, esan dezakegu bigarren pasarte honek egia vs erretorikaren arazo platonikoa aurkezten duela. Irakurketa metonimikoa eginez, Aaronek Legean oinarritutako interpretazio rabinikoa ordezkatzen duela esan genezake, eta Moisesek, berriz, interpretazio profetiko edo inspiratua: gnomismoa vs. errebelazioa, trebetasuna vs. inspirazioa.

Gure testura itzuliaz, arimak aukera egin behar du Aaron eta Moisesen artean: erretorika vs. errebelazioa, abadea vs. profeta, eta, irakurketa biografikoa eginez, Henri senarra vs. François neba, beharbada. “... zeren nik (hain leinu prestuaren ohorea eta jatorria ahazturik, eta baita nigana duzun neba portaera eztia ere) zure aurka altxatu nintzen (nire hutsegiteak gogoratu barik, eta zugandik urrunduz) eta Aaron nebarekin elkar hartuta, gertu egon nintzen zure lanen kontrako epaia emateko, eta bakarrik nengoenean ere marmarka jardun nuen zure aurka. Horregatik damu handitan dago ene kon- 
tzientzia (...) Oh Jainko eskuzabala, neba, eta Moises egiazkoa..."

"...for I (forgetting the honor and adoption of so noble kindred, also Thy so sweet a brotherly behavior toward me) did rise against Thee and (not remembering my faults, but going far from Thee) did agree with my brother Aaron, willing to give judgment against Thy works, and also grudging against Thee privily, which thing causeth me to have a great remorse in my conscience. (...) O bountiful God, brother, and true Moses...(125.orr.)." v

Gogoan izan behar dugu oro har profeziak kolokan jartzen duela autoritate rabinikoa. Hala ere, Numeroak 12-ko pasartean autoritatea profetari ematen zaio, eta, areago, legeak ez du berarengan eraginik. Ohar gaitezen pasarte hau absolutismo politikoaren erakuntzaren testuinguruan interpretatzen badugu, Moises-Erregearen identifikazio bikoitzak zera dakarrela, Jainkoak berak hautatu duela bien artean eta ez herriak, edo gorteak, edo zaharrek edo parlamentuak (hau da, Çiden ageri zaigun arazo bera, ohoreen arteko gatazka). Gainera, ildo horretatik jarraiki, erregea kritikatzeak bekatuaren zama dakar, estigma. Guztiei eragiten dien legeak ez dauka indarrik erregearengan, eta hark nahi bezala apur dezake.

Lehenago aipatu dudanez, bizitza errealean Margarita intrigetan ibili zen senar deseredatuarekin bere nebaren kontra, Henriri Nafarroako erresuma berreskuratzen laguntzeko. Testuinguru politiko honen berri eman nahi izan dut Margaritak testuan aipatzen dituen "hutsegiteak" aztertzeko ${ }^{51}$.

Moises emakume arrotz batekin (eta arrotz baten alaba gainera) ezkondu zen, hau da, ez zion endogamia tradizioari jarraitu.

Moisesek hilketa egin dezake zigorrik hartu gabe, baina gainerakoek ez.

Hauxe da proposatzen dudan irakurketa: emakume arrotzarekin ezkontzea beste herri batzuekiko bake aliantza da, hots, sistema zaharreko errege/erreginek beren-beregi debekatuta zeukaten ekintza politikoa. Aldi

v Car oubliant I'honneur du parentage,

L'adoption de sy noble lignage.

Vostre tant doux et fraternel recueil.

Montée suis contre vous en orgueil.

De mes forfaitz ne me suis recordée:

Mais m'esloingnant de vous, suis accordée

Avec Aaron. mon frere, en trahison. Nomb. 12.

Voulant donner à voz oeuvres raison,

En murmurant de vous tout en secret

Qui me devroit donner un grand regret.

Helas ! mon DIEU, mon frere et vray Moïse. 
berean, horiexek ziren sistema zaharreko aristokratek zeuzkaten eskubide biak: mendekurako eskubidea eta euren etxearen interesen alde jokatzeko independentzia. Nobleak behin gortesau bihurturik, euren kexua izango zen erabaki politiko inportanteak hartzerakoan sarritan errege/erreginak bazterrean uzten zituela. Baina Aaron Henrirekin identifikatu ahal bada, artean ez zen gortesaua.

Testura itzuliz, arimak okerreko bidea hautatu du (erreotorika egiaren ordez?), eta horregatik deskomekatua da, gortetik kanpora botea: "Eta horrela dendetatik eta jendearen bizilekuetatik egotzi ninduten (legentsu baten moduan)"

"And so was I put (like a lazar) from the tents and habitation of the people. (125)."w

Eta ostera ere, barkamena iraina baino sendoagoa da: "Ulertuidazu orduan, eta barkatu nire ezjakintasuna, zure arreba izateko bezain leinu handikoa naiz eta."

"Thou shouldst not to such a good turn unto such a poor woman as I am (126)."

"Take my meaning then, and excuse mine ignorance, since I am of so great a kindred as to be Thy sister (126)."

Hurren, arimak bere nebaren lurrak aitortuko ditu bere senipartetzat, eta onartuko du etxe bakarra izan behar duela, nebarena alegiax. Horrela, kontalariak ezkontzaren gaiari helduko dio, eta hemen aipatu dugun auziari, hots, emakumeei bi eginbehar moralen artean planteatzen zitzaien dilema: alde batetik gurasoei obeditu beharra, eta bestetik euren senarren interesak zaindu beharra, senarrak gurasoen lehiakide izanik lurraren baliabide mugatuetan oinarritutako ekonomia batean.

\footnotetext{
w Ainsi je fuz mise, comme ladresse.

Dehors du parc du peuple et de la presse:
}

1548ko edizioan: For I became a lazar, so that whan any body shulde loke upon me, they myght wele se that I had not bene wyse. And so was I put out from the tentes and tabernacles of the people. bycause that a sycke bodye maye infecte them whych be in helthe

$x$ I have done the evyll, and thu gevyst me good for it, I am thyne, and thu sayest, thu arte myne. Even so I am, and wyll be so for ever. I feare nomore the great folyshenesse of Aaron. for no man maye separat me from the. Now that we are brother \& syster togyther. I care very lytle for all other men. Thy landes are myne owne inherytaunce. $\left[{ }^{*}\right]$ Lete us than kepe (if it please the) but one howsholde. Syth it have pleased the to humble thy selfe so moche, as to joyne thy hart with myne. in makynge thy selfe a levely man, I do ryght hartely thanke the And as to do it as I ought, it lyeth not in my small power. 


\subsubsection{Arima, Jainkoaren emazte}

Oinordekoen jabegoa ziurtatzeko emakumearen sexualitatea zapaldu behar zuen gizarte batean, emazte batek senarrari egin ziezaiokeen iraina, definioz, infidelitatea zen ${ }^{52}$. Areago, testu honetan irain hori orain arte aipatutako beste guztiak baino handiagoa da: "Amaren bat bere semeaz ezertarako arduratu baldin bada, inongo nebaren batek arrebaren hutsegitea ezkutatu baldin badu, sekulan ez dut ikusi (edo bestela ikaragarrizko sekretua izan da) inongo senarrak emaztea barkatu izana emazteak iraindu eta berarengana itzultzean."

"If any mother hath taken any care for her son, if any brother hid the fault of his sister, I never saw it (or else it was kept wondrous secret) that any husband would forgive his wife after she had offended and did return unto $\operatorname{him}(126) . " y$

Ereduzko portaeraren eta benetakoaren arteko konparazioa egiteko, testuak ez dio emakumearen jokabideari erreparatzen, gizonaren erantzunari baino. Honela karakterizatzen du senarra: "Euren gaitzaren mendekua hartzeko, hainbatek emaztea heriotzera kondenatzera bultzatzen zituzten epaileak. Beste batzuek, emaztea bekatua egiten ikusita, euren eskuez hiltzen zituzten. Beste batzuek (emazteen hutsegiteak azaleratzen ikusirik) etxetik bidaltzen zituzten, euren lagunengana. Beste batzuek (emazteen gaizkieginak ikustean) gartzeleratu egiten zituzten. Labur esateko, begiratu haien izakerei, euren azken helburua zigorra besterik ez baita".

"There be enough of them which for to avenge their wrong did cause the judges to condemn them to die. Others, seeing their wives sin, did not suddenly spare their own hands to kill them. Others also (seeing their faults appear) did send them home again to their own friends. Others (seeing their

\footnotetext{
y si pere a eu de son enfant mercy.

Si mere a eu pour son filz du soucy.

Si frere à soeur a couvert le peché.

Je n'ay point veu. ou il est bien caché.

Que nul Mary, pour à lay retoumer.

Ayt à sa femme onc voulu pardonner.

Ikus 1548ko edizioa eta eskuizkribuan falta den bertsoa: «Aitaren bat errukitu bada...n: If anye father have had anye pytie upon hys chylde. If anye mother have take anye care for her sonne. If anye brother hav hyd the synne of hys syster, it is thu. I never sawe (or els it was kepte wonders secrete) that ever husbande wolde througly forgyve hys wyfe, after she had hym ones offended, and ded returne unto hym.
} 
ill deeds) did shut them in a prison. Now, to speak short, look upon all their complexions, for the end of their pretense is nothing else but punishment."z

Horren guztiaren xedea edozein gizonen jokaera mesprezatzea da, Jainkoaren portaerarekin alderatuta. Hamaseigarren mendeko Europan, Jainkoaren erreakzioa tentelkeriatzat hartuko zuten. Beharbada Margarita hemen adierazten ari da emakumearen ohorea ez dagoela bere himenean, desproportzio zoroa dagoela bekatuaren eta zigorraren artean. Testuan hauxe da gertaeren hurrenkera: 1) hutsegitea gauza jakintzat hartzen da, 2) gizonen ohiko erreakzioa erakusten zaigu, senar perfektuarenarekin kontrastean, 3) senar perfektu horrek aurretik emandako (eta beraz, galtzekotan diren) ondasunak zerrendatzen dira:

Neu hautatu nau (hainbaten artean, ustez)

Duintasun handia eman dit, Jainkoaren emaztea izatea denik eta duintasun handiena delako. Jainkoaren ondasun guztien erregina, ugazaba eta dama naiz, eta seguru nago bai gorputzez eta bai arimaz (garai hartako hiru gauzarik garrantzitsuenak: itzala edo maila, jabegoa eta segurtasuna). ${ }^{53}$

Ezkon harreman horretan arimak egiten duen lehenengo hutsegitea senarra utzi eta beste "txarrago" bat hartzea da: "Bai, utzi zaitut, eta ahaztu, eta zugandik ihes egin. Neure gogara joateko utzi zaitut. Bazter utzi zaitut txarrago bat hartzeko (...) Baina nora joan naiz? Tristura besterik ez dagoen leku batera (...) Neure borondate gaiztoaz utzi zaitut (...) Eta (neure burua zure maitasunetik hobeto apartatzeko) zure etsaia hartu dut, zein den deabrua, mundua eta haragia"

\footnotetext{
${ }^{2}$ Assez en est qui pour venger leur tort. Par jugement les ont fait mettre à mort. Autres. voyans leur peché, tout soudain A les tuer n'ont espargné leur main.

Autres, voyans leurs maux trop apparentz. Renvoyées les ont chez leurs parentz.

Autres. cuydans punir leur mauvais tour, Enfermées les ont dens une tour. Bref, regardez toutes complexions, La fin n'en tend qu'à grands punitions. Et le moins mal que j'en ay peu sçavoir. C'est que jamais ilz ne les veulent voir.
}

Testuinguru zabalagoxea eman dut frantseseko bentsioan (aurreko oharrekoaren jarraipena da), bide batez erakusteko maitasun motetan, irainetan eta iraindutakoaren erantzunetan ageri den gradazioa. "If any mother...1 never saw it(...) that any husband..." 126 
"Yea, I have left, forgotten and run away from Thee. I did leave Thee to go at my pleasure. I have forsaken Thee to choose a worse. (...) But whither went I? Into a place where nothing is but cursedness. (...) I have left Thee through my own ill will. (...) And (for the better to outdraw myself from Thy love) I have taken Thine enemy, which is the devil, the world and the flesh (128)....'aa

Paragrafo anplifikatu honetan oraindik, gizonaren izena bera ere gorrotatu izana da hurrengo hutsegitea, eta konbentzioen arabera jokatu izana, zintzoz eta bihotzez jokatu ordez: "Eta zugana izan behar nituen maitasun eta karitateari dagokienez. halako moldez ito zizkidaten, non Jesus ene senarraren izena (lehen hain eztia zitzaidana) gogaikarria zitzaidan, eta halako gorrotoa nion ezen askotan burlatan hartzen nuen. Eta (sermoi bat entzutean) gizonen batek esaten baldin bazidan Predikatzaileak ondo dio, nik erantzuten nion, Egia da. Baina nire hitzak hegaz joaten ziren, luma baten moduan. Eta ez nintzen inoiz elizara joaten, itxuragatik ez bazen. Nire egite guztiak hipokresia baino ez ziren, nire gogoa beste leku batzuetan zegoen eta. Zutaz entzuten nuenean ernegatu egiten nintzen, nahiago bainuen neure gogara ibiltzea."

"And as for the love and charity that I should have toward Thee, they did quench it so that the name of Jesus my husband (which before I had found so sweet) was to me tedious, and I did hate it so that oftentimes I did jest at it. And if any man (we hearing a sermon) should say unto me, The preacher saith well, I will answer, It is true. But my words did flee away as a feather

aa Laissé vous ay, oublié et fouy.

Laissé vous ay, pour suyvre mon plaisir :

Laissé vous ay, pour un mauvais choisir

Laissé vous ay, source de tout mon bien,

Laissé vous ay, en rompant le lien

De vraye amour et loyauté promise.

Laissé vous ay : mais oủ me suis je mise ?

Au lieu où n'a que malediction.

Laissé vous ay, I'amy sans fiction.

L'amy de tous digne d'estre estimé,

L'amy aymant premier que d'estre aymé.

Laissé vous ay, ô source de bonté,

Par ma mauvaise et seule volunté.

Laissé vous ay, le beau, le bon, le sage.

Le fort de bras et le doux de courage.

Laissé vous ay, et, pour mieux me retraire

Deuter. 32.

De Vostre amour, ay prins vostre contraire.

C'est l'Ennemy, et le Monde, et la Chair.

Ohartu, bide batez, errosario kutsu zoragarriaz; xehetasun hau bat dator nire tesiarekin. hau da. testu honek Jesus kokatzen duela Mariaren leku tradizionalean. 
doth. And I went never to the church but for manner's sake. All my deeds were but hypocrisy, for my mind was in other places. I was annoyed when I heard speak of Thee, for I was more willing to go at my pleasure (128)"bb

Maitasun eta karitatearen arteko lotura testuinguru augustindarrean jarri behar dugu testuaren interpretazioaren bidez: biak dira jakituria eskuratzeko gogoeta baldintza. ${ }^{54}$ Bestalde, garai hartako bizimodu erlijiosoaren aurkako kritika ere badugu hemen, "kanporako" jokabidearen eta antzinako pentsaera paganoan hain errotutako formulismoaren gaitzespenarekin. Labur esan, autoreak berak adierazten duenez, hauek izan dira hutsegiteak: senarra gorrotatu, bertan behera utzi, harengandik alde egin eta berori traizionatzea, zertarako-eta "beste bati emateko zure lekua", lehen senide-harremanetan ikusi dugun modu berberean ia. Ondoren, senarraren erreakzio posibleak zerrendatzen dizkigu, beti ere modu negatiboan, hau da, Jesusek halakorik egingo ez zuela adieraziz.

- Emaztea burlatan hartu, jipoitu edo hil dezaten uztea

- Emaztea kartzelaratu edo etxetik bidaltzea

- Emazteari bere opari edo bitxiak kentzea

- Emazteari emandako etxe-lurrak kentzea

bb Hemen letra etzanaz nabarmendu ditudan bertsolerroak ez dira agertzen bi edizioetako batean ere. Oharraren amaieran 1548 ko edizioko pasartea emango dut:

Et qui me suis de tous trois acointée,

Et de tous cas avec eux appointée.

Et propre amour, qui trop est faulse et feinte,

A charité de vous en moy esteinte.

Tant que le nom de JESUS mon espoux.

(Que par avant j'avois trouvé si doux)

Avois quasi en hayne et fascherie.

Proverbe 2.

Et bien souvent en faisois moquerie.

Si l'on disoit en oyant un sermon :

Il a bien dit. je respondois: $\mathrm{Ce}$ a mon.

La parole s'en voloit comme plume.

A l'Eglise n'allois que par coustume.

Tous mes beaux faitz n'estoyent qu'hipocrisie.

Car $\mathrm{j}$ avois bien ailleurs ma phantasie.

II m'ennuyoit d'ouyr de vous parler :

$\mathrm{J}$ 'aymois bien mieux à mon plaisir aller.

Erkatu 1548ko edizioarekin:

And so bounde. that no man coulde cause me to humble my selfe And as for the love \& charyte that I shul de have had towardes the, they ded quenche it so that the name of Jesus my husbande, whych before I had founde so swete. was to me tedyouse \& hatefull. So that often tymes I ded jest at it. [*]And if any man (I hearynge a sermon) had sayd unto me, the preacher sayth wele. I wolde afferme it but the worde went awaye from me. as a fether doth in the wynde. I went never yet to the preachynge, but for maner only. All my dedes were playne hypocresye, for my mynde was in other places. I was anoyed whan I hearde speake of the, for I was more wyllynge to go at my pleasure. 
- Senarrak emaztea akusatzea epailearen aurrean

- Senarrak emazteari debekatzea sekulan bere aurrean agertzea edo bere etxera joatea

Horren ordez, hauek dira Jainkoaren baldintzak: "Ene alaba..."

- Zu arretaz entzun eta ikusi, eta zeure entzutea nigana jarri

- Jendearen jokamoldeak ahaztu (ezagun berrienak), eta (Adan) zure aita zaharraren etxea

Nire irakurketan, ohiko jokabidearen eta Jesusen erreakzioaren arteko kontraste honek Legearen (rol maskulinoaren) eta erruki eta mesedearen (Mariak abokatu gisa daukan rolaren) arteko dikotomia ordezkatzen du. Ez da zinpekoen epaimahairik edo abokaturik behar; nahikoa da arimak fiskalaren baldintzak betetzea: bere jatorria eta sustraiak ahaztea, batetik, eta oraingo kontratua betetzea, bestetik. Nire ustez, honek guztionek indibidualtasun urbanoaren eraketara garamatzacc. Testu honen helburua Maria eta beste edozein ararteko ezabatzea delako hipotesia hurrengo paragrafoak sendotzen du, diskurtsoak Mater Nutrix (beatitudeak) gogorazten duen tonu anbiguoa hartzen duenean, gogoz kontra, arimak ez duelako kasurik egin nahi: “... Negarrez hasi zinen. Etorri nigana lanaz nekaturik zaudeten guztiok. Neu nauzue zuok guztiok hartu eta ene ogiaz elikatuko zaituztedana".

"...Thou beganst to cry: Come unto Me all ye which are weary with labor. I am I that shall receive and feed you with My bread."dd

Hurren gogoeta meta-narratibo interesgarria dator. Protagonistak, arimak, dio ez dakiela ea horiek hitz hutsak diren ala benetan Jainkoaren berbak. Honek arima zalantza momentu batean irudikatuko liguke. Aurretik sermoia entzutera joan zen moduan, orain ere argi dago arima ez dagoela aurrez aurre hizketan Jainkoarekin. Biblia irakurtzen ari da, baina maitasunik

cc 1548ko edizioa: "My dere doughter harken, and se, and bowe thy hearynge towardes me. Forget that straunge nacyon to whom thu dedyst ronne awaye and also the house of thyne olde father, where thu hast dwelled so longe Than shall the kynge full of all faythfulnesse, desyre thy bewtie."

dd Venez à moy, vous tous qui par labeur Matth. 11.

Estes lassez et chargez de douleur :

Je suis celuy qui vous accepteray.

Et de mon pain refectionneray.

Ohar gaitezen nire interpretazioak oinarri galdu duela 1548ko edizioari jarraitzeko bagina: “...than begannyst thu to crye lowder. Come unto me all yow whych are wearyly loaden with laboure, for I am he that shall plenteously refreshe yow and feade yow with my breade of lyfe." 
gabe irakurtzen: berriz ere San Augustinen hermeneutika. Arimak irakurri dituen pasarteak aipatzen zaizkigu: mahasti pozoitsuaren konparazioa, Shulamita arimarekin identifikatzen duen alegoria, eta, azkenik, Jeremias (Jer, 3). Aurreko pasarteak maitasun barik irakurri dituen legez, hau ere "bihotzean beldurra eta aurpegian lotsa" dituela irakurri du. Pasarte guztiek. orain arteko ideia bera azpimarratzen dute: Legeak zigor izugarriak ezartzen: dizkio senarra utzi duen emazteari, baina Jainkoak beste era batera jokatzen du, behin baldintzak betez gero, jakina: "Nire borondatea zu obeditzera jarria zegoela jakin bezain laster, (nigan fede bizia ezarri eta) zure gupida. eta ontasunaz baliatu baitzinen, eta, horrela, zu Jauna, ugazaba eta errege zinela (eta zure beldur izan behar nintzela) jakin nuenean (eta lehenago ezkutatuko ninduzula, jendaurrean agerian jarri baino), ez nuen zure bila abiatzeko beldurrik izan, eta, bilatuta, aurkitu egin zintudan".

"For as soon as Thou knewest my will bowed to obey Thee, then (putting in me a lively faith.) Thou didst use Thy clemency and goodness; so that after I knew Thee to be Lord, master; and king (of whom I ought to have fear), then found I my fear to be quenched, believing that Thou were so gracious, good, sweet, and pitiful [a] husband that I (which should rather hide me than show myself) was not afraid to go and seek for Thee; and in seeking I found Thee."ce

Esan dudanez, arimak bete beharreko baldintzak obedientzia agintzea eta Jainkoaren autoritatea onartzea dira (maitasunik gabe irakurtzea testuaren autoritatea zalantzatan jartzea baitzen). Bere aginte eta lekuagatik beldurgarria izateko modukoa bada ere, Jainkoak barruko ona eta handia dauka.

Gogoratu lehen esan dudana intentzioa eta norabidearen gainean, bai idazki katolikoetan eta bai erreformazaleen artekoetan. Garaiko idazki katolikoetan bekatariak salbazioa lortzeko bete beharreko baldintza Mariarengana "bihurtzea" zen. Paraleloki, bide bati jarraitzeak. obeditzea esan gura du, eta

\footnotetext{
ec Car aussi tost qu' avez veu abaissée Ma volunté soubz vostre obeissance. Avez usé de vostre grand' clemence. Mettant en moy une sy vive Foy. Que vous sachant Maistre. Seigneut et Roy,

(De qui devois par raison avoir crainte) Par vraye amour senty ma peur esteinte, En vous croyant mary sy gratieux. Bon, doux, piteux, misericordieux, Que moy (qui tant me devoye cacher) Ne craingniz point de vous aller chercher.
} 
bihurtzea, norabidea aldatzea edo bidea uzteak, ordea, norberaren gogoa edo asmoa erakustea da. Maite izatea, hortaz, norbaitengana edo zerbaitetara bihurtzea da, maite dugun objekturantz egitea, alegia. Maitasuna funtzio bektorea da, norberaren borondatetik xede baterantz ${ }^{55}$. Bihurtze hori garrantzitsua da, hemen Jainkoa utzi eta besterik hautatzea bezala aurkezten zaiguna azken batean Jainkoak gura duenaz bestelako zerbait gura izatea baino ez baita. Infidelitatea eremu honetan norberaren nahiei jarraitzea bezala ulertzen da, Jainkoaren nahiarekin jazargoan.

Horrenbestez, arimari egiten zaion akusazioa bere borondatea erabiltzea da. Hori jatorrizko bekatuarekin erlaziona daitekeelakoan nago, jakituriaren arbolaren interpretazioari eutsiz gero. Horrexegatik esan dezakegu testu honetan ageri den obedientzia konpromisoa paraleloa zaiola teologia katolikoan Mariarenganako bihurtze gisa ageri den guraria. Diferentzia zera da, biguntasun edo malgutasunaren kontzeptua zein puntutan sartzen den jokoan: bitarteko osagai batean katolikoentzat, eta norberaren borondatean erreformatzaileen kasuan. Katolikoek arauaren salbuespenena bilatzen dute; erreformistek, ordea, borondate malgua. Hortaz, azkenen kasuan harremana zuzena izan behar da. Hautatzearen bekatua bera obedientziari kontrajartzen zaio, eta obedientzia ugazaba eta otseinaren edo jaun eta basailuaren arteko kontratuaren zimentarria da.

- Arimak bekatua egin duen lau lekuetan laburbilduta, honakoa esan dezakegu:

- Alaba gisa, arimak aitagandik egin zuen ihes, eta senipartea xahutu zuen: burujabetza.

- Ama gisa, arima lo geratu zen, arrazoimena galdu eta piztikeria egin zuen gorputzarekin: sentsualitatea.

- Arreba gisa, beste neba bat hautatu zuen, benetako mezuaren ordez: hitz jarioa darabilena: erretorika edo trebeziak.

- Emazte gisa beste jaun batzuk hautatu zituen: borondatea.

Honetara laburbiltzen zaizkigu arimak Jainkoarekin dauzkan senide harremanak: "O ene salbagilea, fedearen bidez zurekin errotu eia batu naiz. A zelako batasuna, (fedearen bidez) ziur bainago zutaz. Eta orain seme, aita, senar eta neba deiu ahal dizut. Aita, neba, seme, senarra. O zelako opariak ematen dizkidazun izen horien ontasunaz. $O$, aita neurea, zelako aitatasuna; $O$. neba neturea, zelako nebatasuna; $O$ ume neurea, zelako gozamena; $O$ 
senar neruea, zelako elkartzea! Umiltasunez betetako aita, gure antza hartutako semea, fedeaz eta karitateaz sortutako semea, azken muturreraino maite duen senarra."

"O my savior, through faith I am planted and joined with Thee. $O$ what union is this, since (through faith) I am sure of Thee. And now I may call Thee son, father, spouse, and brother. Father, brother, son, husband: $O$ what gifts Thou dost give by the goodness of those names, $O$ my father, what paternity; $O$ my brother, what fraternity; $O$ my child, what delectation; $O$ my husband, $O$ what conjunction! Father full of humility, brother having taken our similitude, son engendered through faith and charity, husband loving in all extremity (133)." "f

Giltzarria fedea batasuna legez hartzea da, eta giltzarri halaber batasun horren alderdi bakoitzerik eratorritako etekinak: aitatasunetik umiltasuna, nebatasunetik antzekotasuna, fedea eta karitatearen bidetik gozamena; eta. elkarketatik maitasuna. Fedea gurasotasun-haurtasun harremanaren alderdi bietan dago, hori berori izango da geroko jaurespen erlaziorako gakoa. Erreparatu, bidenabar, ordena aldaketari: lehendabiziko antolaeran harremanak antzeko tipoetan parekatzean datza segurutik (aita-semea, menderakuntza; senarra-neba, alborakuntza). Hona hemen bakoitzak arimarekiko daukan eginkizuna: aitak alaba gazte buruarina defendatzea, nebak arimari bere nahigabeetan laguntzea, semeak zahartzaroaren ahuldadean euskarria

\footnotetext{
ffo moñ Sauveur, par Foy je suis plantée. Rom. Il.

Et par amour en vous, jointe et entes.
}

Quelle union. quelle bienheureté.

Puis que par Foy j'ay de vous seureté

Nommer vous puis par amour hardiment

Filz. Pere. Espoux et Frere, entierement

Pere, Filz, Frere el Mary : ô quuelz dọns.

Jean 1.

De me donner le bien de tous ces noms!

O mon Pere, quelle paternite!

O mon Frere, quelle fraternite !

O mon Enfant, quelle dilection !

O mon Espoux. quelle conjonction!

Pere, envers moy plein de mansuetude :

Frere, ayant prins nostre similitude :

Filz, engendré par Foy et Charité :

Mary. aymant en toute extremité. 
ematea, eta senar zintzo eta leialak haren bihotz osoa betetzea. Honek lotura batzuk izan litzake azken judizioarekin.gg

\section{Jaurespen harremana}

Esana dut poema osoak sustrai hartzen duela bi metafora esparru nagusitatik: bata epaiketa eszena eta bestea familiakoa. Azaldu dut epaiketa eszena Etxepare oinarri harturik, eta adierazi dut zelan epaiketa bera ez den zuzenean deskribatzen Margaritaren poeman, baina etengabe dagoela azpitik. suposatua. Ikusi ditugu familia harremanak eta zelan erabiltzen dituen margaritak Bibliatiko aipuak irakurleak nahasketa edo bateraketa espazioak sor litzan, eta halaber, epaiketaren eszena etengabe suposatu egote horrek dakarren pribatizatze prozesua. Orain ikustera goazena zera da, hain zuzen epaiketa eszenaren ordez eskaintzen zaigun itunaren irtenbidea. Itunak bi alderdi ditu: merkata! alderdia eta jaun-basailu alderdia, bietan maila ezberdinen arteko berba ematea izango da, baina, halaber, objektuen edo zerbitzuen trukaketa ere bai. Ituna testuan hasieran datorren bataioarekin ezartzen da, eta ituna bermatzen da azkenean datorren zaldun-guda edo turnamentaren bitartez, hain zuzen epaiketa eszena artezen ordezkatuko duen eszena.

\subsection{Otsein-Ugazaben artekoak}

Arimak bere ahuleziak azalduko ditu: alde batetik bekatu larregi egin ditu eta, bestetik, indarrik bat ere ez du ezagutzarako. Gizakiaren izaera okemaren gaineko leku komunak dira berauek. Hots, autoreak esango digu definizioz arima bekataria dela, edo bestetara, bekatuak bere sustraiak giza ariman dauzkala barrenduta. Arima bekataria izateaz gainera, ararteko eta artekarien hutsaltasunaz jardungo du gero "Ez da gizonik, ez santurik, ez aingerurik zeinaren bitartez bekatariaren bihotza aldatuko denik."

"there is neither man, saint, nor angel for whom the heart of a sinner will change." (117.orr.).

\footnotetext{
gg Or vous ay je, mon Pere, pour defense

Des folles de ma trop longue enfance.

Or vous ay je. mon Frere, pour secours

De mes ennuyz que je ne trouve court?.

Or vous ay je, mon Filz. de ma vieillesse

Le seul baston, support de ma foiblesse.

Or vous ay je l'espoux sans fiction.

De tout mon coeur la satisfaction.
}

1548ko edizioa: Now have I the my father, for defence of my longe youth from wanton folyshnesse. Now have I the my brother, for to socoure my sorowes wherin I fynde non ende. Now have I the my sonne, for my feble age as an only staye. Now have I the a true. \& faythfull husbande, for the satisfyenge of my whole harte. 
Bitartean autoreak Jainkoaren eta arimaren arteko konparaketa Erdi Aroko jaun-basailuaren esparruan kokatuko du, sendiko harremanak ez baitira jabe-mirabeen artekoetatik bereizten; hori bi eratara erakutsiko digu autoreak, alde batetik familia barruko hierarkiaren azpimarratzeaz, hau guztia aurreko atalean ikusi dugu, eta bestetik jaun-basailuaren harremana ugazabaren ontasunean oinarrituz. Testuak azal eta zelai agertu behar du zerbitzariak ez duela zerbitzatzen, jaso baino. Testuinguru honetan interpretatu beharko dira "jainkoaren grazia" bezalako kontzeptuak, eta "lurreko har guztiz biluzia" bezalako adierazpideak: "Helas, zelako ugazaba baina! Beragandik onik ez dut merezi, kontrara baizik, zerbitzari nagia izan natzaio eta..."

"Alas, what a master! Without having deserved any goodness of Him but rather served Him slothfully..."th.

Esaldi honetan egitura hierarkikoa gorde da; otseinaren kalitate faltak ugazabaren kalitatea azpimarratzen du. Horrelako konparaketak ez dira berriak, gogoratu Mio Ciden "como oviera buen vasallo si oviera buen señor." Honek pentsamendu magikoarekin lotzen gaitu, zeinetan uste baita lurreko gertakariak zeruko gertaeren ispilu baino ez direla (ikus oharretan lehen emandako patriarkalismoari buruzko aipua). Beraz, hortik hurrengo urratsean, goiko katenbegiko nolakotasunak beheko katenbegikoek jasoko dituzte herentzian. (Çiden kasuan), eta are hurrengo urrats batean, herentzia hori ez onartzea izango da bekatu egitea (Margaritaren kasuan).

Goazen astiroago: "Helas, ene Jainkoa, ez zaitut bilatu, baina hegaz eta ihes egin dut zugandik; eta nigana zure azpira makurtzen zara orain, zer-eta lurreko har erabat biluzia baino ez naizen honengana".

"Alas, my God, I did not seek Thee, but fled and ran away from Thee; and here beneath Thou camest to me which am nothing but a worm of the earth all naked."ii

"Lurreko har erabat biluzia"ren konparatzeak espazioaren kontzeptua erakusten du era bitara. Manda batetik, Katea nagusiaren metaforari buruz

th Las! quel maistre, sans avoir desservy

Nul bien de luy, mais l'ayant mal servy.

1548: O what a master is that, without deservynge any goodnesse of hym? I served hym slouthfully:...

ii Helas! Mon DIEU, je ne vous cerchois pas.

Mais vous fuyois en courant le grand pas ;

Et vous ça bas à moy estes venu, Jean ?

A moy, qui suis ver de terre tout nud. 
Lakoffek eta Turnerrek egin ikerketei jarraiki (1989), harra bizidun ibiliarien arteko katenbegirik beherengoena litzateke, baina, oroz gain, bizidun horiek guztiek elkarrekin duten zerikusi handiena zera da, lurjabetzan oinarritutako gizartean dituzten lurrarekin uztartutako hartu emanak. Lakoffek eta Turnerrek 1989an azaldu zuten zertan zen "The Great Chain of Being Metaphor". Katea horren arabera, izadiko izaki guztiak hierarkikoki uiertzen ditugu; horrek ez dakar poperiza izakiak hierarkian batean daudena berez, baizik eta gizakiok mendebaldeko kulturan halan ikusten dituguna. Adibide klasiko bat jartzearren, "Akiles lehoi bat da", ez gabiltza Akiles, Lliadako pertsonaia lehoi batekin sofistikatuki konparatzen - ezaugarri txikiagoak edo sememak erkatuz Greimasen eskolaren arabera kasu -, baizik eta lehoi batez mendebaldeko kulturan (Indoeuroparrean segurutik) gizakiok dugun irudiarekin baino. Bide honetatik, oso esanguratsua da euskal atsotitzetan lehoiaren ordez hartza agertzea: "otsoak hartzari min legio" hierarkia horri erronka eginez (in "Izpazterreko errefrauak"). ${ }^{56}$

Beste manda batetik, maila izpiritualean, lurra aireari jazartzen zaio, eta negatiboki polarizatu, batik bat arimak "hegaz eta ihes asago zugandik" egin duenean, 57 Esaldian zehaztu gabe lotu diren espazioak "azpira," "nigana zatoz," denak dira hizlariaren ikuspegitikoak, eta hartu eman hierarkikoa azaltzeko hor jarriak.

Jaun-basailu erlazioak bataioaren bitartez sinbolizatzen dira: bataioan arimaren "lagunek" eutsitako aginduak dira arimak eginbeharreko lanak. Bera zerbitzari txarra izatea agerian azaldu da aginduok jan egin dituelako. Otseinaren eginbeharrak hauexek dira:

(Zure nekaldiaren bitariez halakoa izatea nire haragiaren mortifikazioa sentitzerainokoa senti dezadan.) Being such always through Thy passion to feel the mortifying of my flesh

(Zeugaz beti egotea gurutzean, non herioa bera josi duzun -hala sinesten baitut- eta bertan hilik utzi) to be always with Thee in the cross, where Thou hast nailed (as I do believe) and yielded death dead

(bekatuak oro ere utzi zenituen bezala, nik neuk sarri askotan bertatik eraitsi eta berriz askatu baditut ere) and also all sin, which I have oftentimes 
taken down again and untied.ij

Kontrakarra, ugazabaren betebeharrak hauexek dira:

(fedez eta sagaramenduz ni ohartaraztea) to warn by faith and sacraments

(otoitzez niri agirika egitea) to admonish me by preaching

(zure gorputz onurakoaren eta odol santuaren hartzeaz ni lasaitzea) to comfort me by the receiving of Thy worthy body and holy blood

Betekizun hauen gabeziak batzuetan atxakia dira mirabearen alde, horrexegatik dio arimak burua ateratze aldera: "Sarri askotan apurtu izan dut zugazko ituna, ezen nire arima gaixoari sobera eman izan baitzaio jaten ogi txarra eta dotrina kaltegarria"

"Ofientimes have I broken with Thy covenant, for my poor soul was too much fed with ill bred and damnable doctrine."

Ohartu gaitezen bi betebeharron tankerak arras diferenteak direna: otseinaren eginbeharrak gogo-kidetasuna (bestera esateko adiz-kidea izatea), laguntzioa eta bekatua saihestea dira (berau dena delarik ere). Ugazabaren betekizunak, berriz, apaiztasunari datxezkio: sagaramenduak eta dotrina. Horregatik hain zuzen ere ugazabari ogi txarra eta dotrina kaltegarria leporatzearen ustezko inkontsistentzia abadeen kontrako kritika bilakatzen da. Bi kide daude, kideok ez daude maila berean, eta bi maila diferente horien artean kontratua ezartzen da bataioaren bitartez.

\subsection{Zaldun-gudaren eszena: bekatuak eskaini grazia jaso}

Heriotza da maitaleen arteko azken lotunea. Holako lotura bi lokarri moduren bitartez aztertzen da testuan: heriotza-bizitza eta arima-gorputza. Maitasunak (Jainkoak) lotu ditu heriotza eta biziza elkarrekin. Gurutzearen misterioaren bitartez, heriotza ez da gehiago atzen azkena. Holaxe lotu ditu

\footnotetext{
ii Ce qu'ont promis mes amys au baptesme: Psal. II 8.

EI que depuis j'ay confermé moymesme

(Qui est sans fin de vostre passion Roma. 6.

Sentir en moy mortification. Psal. 43.

Estre tousjours avecques vous en croix.

Où vous avez cloué. comme je crois.

Ei rendu morts la Mort er tout peche.

Que souvent jay reprins et detache). 
maitasunak alde bi-biak: "bizitza hilez, eta bizitza amairik gabea". "Bizitza hilez" honek bizitza erreala esan gura du, eta "amaigabeko bizitza" esapideak heriotzez osteko bizitza esan nahi du. Beraz, Jainkoarenganako lotu desira honetan bi aukera ditugu: edo heriotza badator arimak Jainkoa aurki dezan, edo Maitasunak arima itxuraldatzeko mirakulu mistikoa egin beharko du.

\subsubsection{Lotunea}

Gurutzearen misterioa baino lehen heriotza zortotza zeñ denongan, baina, "gorputza eta arimaren arteko kopulazioa kautan harturik, euron ordena, maitasuna eta adostasuna, tristezia gehiena bata bestearengandik aldentzean zetzan".

"considering the copulation of the body and the soul, their order, love, and agreement, where the extreme sorrow was in the departing one from another." $k \mathrm{k}$

Gorputz-arimen erlazioa elkarrekiko maitasuna zen (piztiazaletasuna edo zoofilia, lehenago esan bezala) eta horregatik zitzaion heriotzari beldurra. Baina orain bi kontzeptu ditugu gure helburuetarako interesgarri. Bata heriotzaren zorroztasuna (ley severa, Quevedok): zurruna dena ez da Jainkoaren Legea Etxeparerengan bezala, baizik eta lege naturala, eta lege naturalak dio arima eta gorputza elkarrengandik aldenduko direla. Bigarrena zera da, Jesusek heriotzaren aurkako borroka irabazi zuenez gero, berarekiko maitasuna sortarazi ziola arimari. Era honetara, arimak ez du areago egon gura gorputzarekin; zelanbait indartsuenarekin egon nahiago du. Behin zurruntasuna legera igarota, eta gero legetik heriotzara, ez zaio jada beldurrik Judizio Jeneralari." Hemen Jainkoa da oreka-haizutasunarekin (equitas-errukia) bat egiten dena. Horrekin guztiarekin ere, autoreak gordeko du azpian

\footnotetext{
kk. ('ar où la mort, avant le grand mystere

De ceste croix, estoit à tous austere, Ecclesiaste

Et n'y avoit coeur qui n'en eust frayeur,

En regardant sa face ei sa rigueur,

Veu l'union qui est de l'ame au corps.

Et l'ordonnance, et l'amour, et accordz.

Dont la douleur estoit du separer.

Extreme acces pour tout desemparer :
}

If I548ko edizioun: Now syth that deathe is so plesaunt a lyfe, that she pleasith me more than feareth me. than ought I to feare nothynge but the rygh! judgement of God. All my synnes with hys just (Fo.32.) balaunce shali be wayed \& shewed openly. Thys that I have done. also my thought anc worde shall be better knowne. than if they were written in a rolle. And we maye not thynke that charyte wolde offende justyce \& truthe. For whoso ever doth lyve unfaythfully, shall be ponnyshed in everlasytnge payne. 
kontu-liburuaren irudia eta bekatuen gaindikinarena.

Katolikoen iruditeriatik ateratako beste ezaugarri bat bekatuen erakustea da. Katolikoen psikologian bekatuak garbitzeko modu bat eurek plazaratzean, argitaratzean, begietaratzean zetzan; iritzi publikoari erakutsiz, honetara ohore kopurua, balio pekuniario gisa (prestigioa, boterea eta hortaz, bezeroak) lotsarekin orekatzen zen. Testu honetan garrantzizkoa dena zera da, norberaren jokaeraren alde isildua - hitzak eta gogoetak - erroilu batean idatziak balira bezala erakusten direla--eta holan Jainkoak jakin badakiela azpimarratzen da. Ez da bekatuen garbiketarik bekatuok publiko egitearen bitartez konfesioañ edo aitortzan bezala, fidantza kriminalaren ordainketa baino. "Charity does not offend justice and truth," "Karitateak ez dio irainik egiten zuzentasunari eta egiari" esaldiak esan gura du zorren ordainketa eskuzabalak ez lukeela justiziaren kontra egingo (hots equitas-en kontra), zeren zorra kitatzeko baldintza bakarra fedea edukitzea bai-bailitzateke (eta ez pietatea edo errukia).

Arimak berez irabazi du galera, baina Maria-mesedea zen bide judizial hura ez da aurrerantzean. Ustezko oztopo hau gainditzeko bidea fedea da; fedea, ezinezkoan sinestea, hots, Jesusek ekintza gaiztoak bertute bihurtuko dituela sinetsi behar, eta zeren bidez eta ezkoniza itunaren bitartez. Fedea, beraz, oso tankera zehatz bateko erlazioa da, equitas edo mesedearen oso bestelakoa, baina antzerako funtzioa beteaz. Hara hemen arartekoa zen aldetik aitortzaren kontrako erasoa: "Hortaz, O Jauna, nork kondena nintzake, Bera (epailetzat emana zaidana) nire senarra, nire aita, eta nire aterpea baldin bada?"

"Then, O Lord, who shall condemn me. since He (which is given me for a judge) is my husband, my faither, and my refuge?"mm

Epaiketa honetara dator:

- Aita epailea da; alabaina, edozeir aita onen jokaera naturala da bere umea inoiz ez kondenatzea, betiere zuritzea eta defendatzea baino. Horixe litzateke gure egungo terminoetan errugabetasun suposamen-

mm Las, mon DIEU, non : car la Foy invisible

Matth. 19.

Croire me fait, que tout mon impossible

Est tresfacile a vous, tant que mon Rien

Convertissez en quelque $=$ de bien.

Rom. 5.

Donc, Monseigneur, qui me condemnera ? Rom. 8.

Et quel Juge jamais me damnera,

Quand celuy là qui m’est donné pour Juge

Est mon Espoux, mon Pere et mon refuge?

Psal. 8.9. 
dua.

- Akusatzailea Jesus da eta, aldi berean, bere erredentorea da. Areago, ez da bakarrik haren akusatzailea, baizik eta haren legegizona (bozeramalea) ere bai. Akusatu beharrean eskusatu egiten du, eta beragatik mintzatu. an

Europako hamaseigarren mendeko pentsamoldeak giza izaera definizioz gaiztotzat zuen. Beraz, Jainkoagazkoak arima goraltxatu arren, bada isuri arazo bat garbitu beharrekoa, arimak txarrerako eroria izatea, alegia. Autoreak dakarren irudia turnamentarena da, Jesus eta Bekatuaren arteko zaldun-guda. Borrokaren ostean, Bekatuk ez du indarrik (prestigiorik) inor infernuan edukitzeko, galdu ditu bere bezeroak ohorearekin batera. Segituan autoreak metafora destolesten du: Jesusenganako maitasuna bekatuarenganako eroria baino indartsuagoa da. Justa eszena honetan, barkatu den bekatu bakoitza Jesusen gloriarakoa da (gloria zaldunerian ulertzen den bezala), zenbat eta bekatu gehiago, orduan eta postura edo apustu zailago "faborito" ez zenarentzat. Jesusek bekatuen zorra kitatzen du. Trukaketak ezkontzan oinarritzen dira: bere ondasunak gure ondasunak dira Bataioan agindu baitzizkigun; bere merituak gure merituak dira bere karitateagatik, eta gure bekatuek bere gloriarako balio diote. Puntu honetan, karitatea zuzentasunari edo berdintasunari jazartzen zitzaion esaldi hura argituko da: fedea gure aldean da, eta karitatea bere aldean da, eta bi-biek betetzen dute mesedeak edo errukiak dotrina katolikoetan egiten duen rola. Fedeak (oparia jadesteko) karitatearen bitartez lotuko ditu: "Otsein umila bere jabearekin. (...) Ezaguturik neurez ahula naizena eta Jainkoarekin indar-indartsua..."

nn 1548 ko ediziotik: O redemer, here is a great love. We fynde but fewe suche men of lawis. Swete Iesus Christ, it is unto the that I am a detter, yet dost thu both praye, and speake for me. And moreover whan thu dost se that I am poore, with the abundaunce of thy goodes thu dost paye my debte (...) O my father, dost thu vouchesave to be my judge, not wyllynge the deathe of a synner. O Jesus Christ, true fysher, and saver of the sowle, frynde above all fryndes, so thu beynge nry man of lawe. de(Fo.33.)dyst excuse and speake for me, where thu couldest justly have accused me. i feare nomore to be undone by any man for the lawe is satisfyed by the for all. My swete spouse hath made the payment so habundaunt, that the lawe can aske nothynge of me but is payed of hym. For as I beteve. he hath taken all my synnes upon hym, and hath geven me in plice of them, hys owne goodes in habundaunce. 
"the humble servant unto his master. (...) Knowing that as for myself I an weak and with God 1 am right strong..." oo

\section{Ondorioak}

Margaritaren Mirailak Andre Mariari emandako rola Jainkoagazko jaurespen erlazio feudala bilakatzen du. EQUTTAS edo berdintasunaren kontzeptua, legearen zurruntasuna biguntzeko tarteko zoru bezala ulerturik, mesedearen edo errukiaren rol femeninoa bilakatu zen; Jainkoaren legea. zurruna, Andre Mari biguna. Aitzitik, Margaritaren irudi berrian malgutasunak arimaren borondatean egon behar du, eta Jainkoarekiko erlazioak ispilatzeko bi kontzeptu darabiltza: fedea arimarengandik Jainkoarenganaino, eta. karitatea Jaikoarengandik arimarenganaino.

Equitas: legea berdintzea $\rightarrow$ epaiketa: mesedea-errukia vs jaurespena: fedea-karitatea

Epaiketa eszena familia harremanen eszena batera aldatuz gero, Margaritak Jainkoa eskainiko du Aitatzat eta epailetzat, eta Jesus semea akusatzailetzat eta senartzat; eta arima emakumearekin identifikatzen da eurekiko harremanetarako: alaba, arreba, ama eta emaztea.

Esango nuke Europako hamaseigarren mendeko goi mailetakoek ezkontza jaurespen erlazio gisa ulertzen zela. Jesus-senarrak itzala irabaziko: du bere emazte-arimaren fedearen bitartez, eta arima-emazteak baliatu ahal ditu bere senar-Jesusen ondasun-izenak. Atzean dautzan irudietako bat arimaren faboreagatik Jesusek eta Bekatuak duten turnamenta da. Fedea jauntzaren ezagutza da; trukean jaunaren karitateak bekatuak ordaintzen ditu. Ez da tartekorik, harremanak ez du bitartekorik.

Goi mailako aristokratentzako harreman biribilenak familiaren barrukoak ziren. Emakumeak aitari obeditu behar zionez, eta begirunea zor nebari, baina, era berean bere senarra ere zerbitzatu behar, bada emakumearentzat ere, segurutik lehian leudekeen bi etxe desberdinen arteko tentsioa lasaituko

oo $Y$ a il rien qui me puisse plus nuire.

Si DIEU me veull par Foy a luy conduire?

Jentens la Foy toute telle, qu'il fault, Ephes. 2.

Digne d'avoir le nom du don d'enhault :

Foy, qui unit par Charité ardente

Au Createur sa treshumble servante. (...)

Trop roible suis en moy, en DIEU tresforte (...) 
zen baldin eta aita eta senarra berbera baziren; hartara etxe bakarra zen gobernatzeko eta tentsioa saihestuko zen.

\section{Bibliografia erabilia}

Aristotie. On Rheioric: a Theory of Civic Discourse. Itzulpena, oharrak eta eranskinak: George A. Kennedy. New York eta Oxford: Oxford University Press. 1991.

Belsey, Catherine. "Chapter 6: Silence and Speech," The Subject of Tragedy. London: Methuen. 1985: 149-191.

Cicero. Topica. Itzult. H. M. Hubbell. The Loeb Classical Library. Cambridge (U.S.) eta London: Harvard University Press. 1949 1993: 382-4.59 orr.

Eden, Kathy. Hermeneutics and the Rheforical Tradition: Chapters in the Ancient Legacy and lts Humanist Reception. New Haven: Yale University Press. Series: Yale Studies In Hermeneutics. 1997.

Elizabeth [. "The Glass of the Sinful Soul" (1544). Elizaberh's Glass. Marc Shell (ed.) Lincoln \& London: University of Nebraska Press. 1993.

Elizabeth 1. A Godly Medytacyon of The Christen Sowle, concerninge a lose towardes God and hys Christe, compyled in frenche by lady Margarete quene of Naverre, and aptely translated into English by the ryght vertuouse lady Elyzabeth doughter to our late soverayne Kynge Henri viij, 1548. Lehen edizio elektronikoa Women Writers Project, 1999. Iturria: Iehen edizioa, 950rr. Octavo. Kopia iturriaren jabca: Folger Shakespeare Library. Apal zenbakia: STC 17320. URL: http://textbase.wwp.brown.edw

Etxepare, Bernard. Lingua Uasconum Primitiae (1545). Bilbao: Euskaltzaindia. 1995.

Fauconnier, Gilles. Mappings in Thought and Language. Cambridge (U.K.): Cambridge University Press. 1997.

Garai, Koldo J. "The concept of Sin in Bertrand de Etxepare's Lingua Uasconmm Primitiae." Ling-715 Applied Linguistics: Metaphor izeneko mintegirako idavitako artikulua. Irak.: Joseph Grady. University of Georgetown, 1999.

Goyhenetche, Jean. For et coutumes de Basse Navarre. Donostia (Spain); Baiona (France): Elkar, 1985

Grady, Joseph. "A. Typology of motivation for concepiual metaphor: Correlation vs. resemblance." G. Steen \& R. Gibbs (Eds.). Metaphor in Cognitive Linguistics.

Philadelphia: John Benjamins. 1999:

Grady, Joseph. "Theories ARE Bunlongs revisited". Cognizive Linguistics 8.4 (1997): 267 290.

Grady, Joseph. In preparation. "Primary source concepts, primary target concepts and primary scenes." Chapter 5 of Foundarions of Meaning (Manuscript). Nik eskuizkribua erabili arren argitaratua dago.

Lakoff, George and Mark Johnson. Metaphors We Live By. Chicago: Chicago University Press. 1980. 
Lakoff, George and Mark Turner. More than Cool Reason: A Field Guide to Poetic Metaphor. Chicago \& London: The University of Chicago Press. 1989.

Malina, Bruce I. The New Testament world: Insighis from culural anfiropology. Louisvilfe, (Kentucky): Wesiminster/John Knox Press. Rev. ed. 1993: pp. 63-89.

Marguerite de Navarre. Le Miroir de l'ame pecheresse de Marguerite de Navarre: an electronic transcription." Transkribatua eta kodetua: Mary Skemp-ek. Editatua: Miranda Beaven Remnek-ek. Oinarritua: 1873ko edizioan, Les Marguerites de la Marguerite des Princesses, Félix Faure-k editatua. (Librairie des Bibliophiles. Paris, 1873, tome 1, pp. 13-68.). Electronic Text Research Center, University of Minnesota: Minneapolis, MN. 1998. Prepared by The Early Moderm French Women Writers Projed. Miranda Beaven Remnek, Proiektuaren zuzendaria. Ekaina 1999. URL: hutn://erc.lib.umn.edu/erc/frenwom.htm

Mark Turner. "Figure." In: Cristina Cacciari, Ray Gibbs, Jr, Albert Katz, and Mark Turner. Figurative Language and Thought. New York: Oxford University Press, series: Counterpoints: Cognition, Memory, and Language, 1998.

Ong, Walter J. Orality and Literacy: The Technologizing of the Wurd. London and New York: Routledge. 1995 [1982].

Ortony, Andrew (arg.) Metaphor and Thought. 2.ed. Canbridge University Press. 1993

Parr, Susanna. "Susanna's apology against the Elders, 1659." In: Graham, Elspeth et al (Eds.). Her own life: autobiographical writings by seventeenth century Englishwomen. London; New York: Routledge. 1989: 101-115.

Rich, Adrienne. Of Woman Born: Motherhood as Experience and Institution. New YorkLondon: W.W. Norton \& Company. 1995 [1985, 1976].

Roulker, Nancy Lyman, Queen of Navarre: Jeanne d'Albret 1528-1572. Cambridge (U.S.): Belknap Press of Harvard University Press. 1968.

Saint Augustine. On Christian Doctrine. Ltzulp. D. W. Robertson, Jt. Upper Saddle River, NJ (U.S.): Prentice Hall. The Library of Liberal Arts. 1958.

Shell, Marc. Elizabeth's Glass. Lincoln \& London: Nebraska Universily Press. 1993.

Turner. Mark and Gilles Fauconnier. "A Mechanism of Creativity." 1997. 9/15/98. URL: http:/www.wam.umd.edu/-mturn/WWW/mechanism.html.

Turner, Mark and Gilles Fauconnier. "Blending as a Central Process of Grammar." 4/27/99. URL: http://www. wam.umd.edw/mtum/WWW/centralprocess/www/centralprocess.html Expanded web version of Gilles Fauconnier and Mark Turner, "Blending as a Central Process of Grammar." In: Adele E. Goldberg, ed. Conceputual Structure, Discourse, and Language. Stanford: Center for the Study of Language and Information (CSLD), distributed by Cambridge University Press. 1996: 113-129.

Turner. Mark and Gilles Fauconnier. "Conceptual Integration and Formal Expression." 1995. 2/16/99. URL: http://www.uoregon edu/-rohrer/tumer.htm

Turner, Mark. Death is the Mother of Beauty: Mind, Meiaphor, Criticism. Chicago and London: The University of Chicago Press. 1987.

Tumer, Mark. Reading Minds: The Siudy of English in the Age of Cognitive Science. Princeton. New Jersey: Princeton University Press. 1991.Turner, Mark. The Literary Mind. New York and Oxford: Oxford University Press. 1996. 


\section{Oharrak}

I Oso eztabaida interesgarria zaigu, batez ere postkolonialismoaren atzaparretan erortzeko arrisku bizian gauden guri cuskaldunol, Mark Turnerrck bere Reading Minds 1991 ko lehen atalean egiten duena: "Pretext: Professing English in the Age of Cognitive Science" [3]-24 orr. Guztiz bat nator hangoarckin. Literatura ezin da botere jakin bat oinarrituko duen lestu kanonikoen erreskada izan, edo erreskada horren kontra eraiki daitckeen beste erreskada alternatiboa: adibidez, eta horrelako bihurketarik gure literaturaren historian gerta baledi homek izan lezakeen onuragamiasun ideologiari garat bat ere kendu gura izan barik ere. Exxepare azterzetik hasi beharrean Milia Lasturkoagandik hasiko bagina bezala (Leizaolak legez) edota Orixe aziertu beharrean Errose Bustintzaren ipuinak ikertuke balin (ailedi izan!). Ondino erradikalagoak izan behar dugu: S.itcratura giza fakultate kognitiboa da, zeinaren bitartez mundu posibleak ela horicn csangurak eraikiten ditugun; beraz, literatura penisatzeko eta arrazoitzeko mekanismoa da.

2 Perelmanek cta Olbrects-Tytecak 1958ko euren liburu klasikoan (orain gutxi espainolera itzuli da lehengoz) bereizlen dute inknnpatibilitatea eta kontraesanat. Jar bedi irakurka Cicerok bere Topican "aribiguotasuna" azaltzen dueneko kokaeran, hots, legea noiz eta zelan den anbiguoa. Bi perpausen arteko kontraesanak sistema formalen bat eskatzen du, ez badago sistema formalik kontraesana ez da existitzen. Inkonpatibilitatea akdiz zirkunstantzia kontingenteck, gertaera partikularrek edo gizakien erabakiek eraikitzen dute. Inkonpatibilitateak saihesteko hiru hurbilketa azaltzen dituzte Perelmanek eta Olbrechts-Tytecak. Lehenak cdo logikoak aldez aurretik egon daitezkeen zailtasun eta arazoak ikustea litzateke, eta horrela legeak eta arauak: aplikatuz alboratzen dira imajinatu diren inkonpantibilitateok. Honi dedukzioa deitzen diote. Bigarrena da gizaki praktikoak egingo lukeena, arazoei aurre eginaz biderdiratu heinean, ez lehenago, kontzeptuak berplanteatuz eta berrezarriz bakoitzean, behar den heinean bakarrik. Lehen hurbilketa gizaki teorikoarena bazen, hau gizaki praktikoarena da, zeinak ez duen lar agindu nahi, bada ezpada, egoera berrietara makurtu ahal izateko. Eta hirugamena da gaixotasun diplomatikoa deitzen diotena, arazoari aurre egiteko momentua alzeratzea edo arazoarekin topo egingo den egocra edo kokagunea saihestea. Guri lehen biak interesatzen zaizkigu gure ahozkotasunidatzizkotasun dikotomiarako.

3 Hau izaten da ( ciaya fbarrak eman ohi duen dikotomia: lege idatzia = dedukzioa (lege orokorraren interpretazioa kisu partikularrari aplikatu) vs. Forua = indukzioa (kasu partikularretik lege orokorrera. askotan lege orokor hori hitzetaratu ere egin behar ez delarik). Ez nioke abaguneari igarotzen utzi nahi, fortaren azterketa erretoriko-literarioa egitea nori dagokion galdetu gabe: abokatuei?, historiagileei? Ala literatur kritikoei? Esan behar dut ikaragarri eragin ridala eta didala abiapuntu honek nire ibilbide akademiko osoan. Adibidez Ayalako foruari Celayak idatzitako sarrera edota Celaya Ibarra, A. Vizcayay su fuer civil. Iruñea: 1965.

4 Ikus Mieke Balen Narratology: Introduction to the Theory of Narrative (1985), (Espainolera ere itzulita daukazue Cátedran) batez ere tokalizazioaz hitz egiteko erabilizen duen "testua", zein den erliebe batean ageri den kontaketa.

Bestalde lehen aipatu dudan Euskal Foruaren azterketa erretorikorako pertinentea dugu guztiz Mark Turnerren The Literary Mind (1996) liburuko lehen atala: "Bedtime with Shahrazad" (3-11 or). Atal honetan. Tumerrek parabolaren bidezko pentsabidea azaldu nahi digu; halan da ezen sizakiok egoera irreal (iraganeko zein alegtazko) batetik orainaldiko egoera batera informazio eta egitura beharre koenak proiektatzen ditugula. Proickxio hori image-schema edo irudien hezurdura soildua proiektatuz egiten da hein handi batean.

Bide honetatik Erdi A roan exempln edo comsejek zergatik zuten halako garrantzia igartzera hel gaitezke, literatura didaktikouat jo beharean gnomiko bezala definituz. Adibidez, egia baldin bada Erdi Aroko mundu muslimean, Granadan esaterako, vizir izatera zapatagin xume bat hel zitekeela 
baldin eta literatur ahalmenik bazuen, honek agian erakuts lezake gizarte hartan pentsaera paradigmatikoak (Aristoteleren paradeigma kontzeptuaren ildotik) lehentasuna zuela.

Aristotelek paradeigma azaltzeko (enthymemari jazarrita) honako adibidea jarzen du: Iraganean, persek Egipto inbaditu duten guztietan gero Greziari eraso diote; gaur persek Egipto inbaditu dute. beraz, goazen Pertsia erasotzera berandu baino lehen. Euskal Foruek ere arrazoibide paradigmatiko honi emango ei liokete lehentasuna. Aristotelek dio paradigma indukzio bat dela, eta ez doala ez aldesik orokortasunera, ez orokortasunetik aldera, baizik eta aldetik aldera, berdinetik berdinera. gauza bi genus beraren barruan daudenean baina bi horietarik bat hobeto ezagutzen denean. Hau da paradigma premisa partikularretik ondorio partikularrera doan arrazoibidea da, lotura unibertsala esplizitu egon behar ez delarik. Eta honek analogia aztertzera abiatzen gaitu.

5 Gogoratu, bestela, kontrarreforman nori zuzendu zitzaion Axular bera: erdi mailako kultura zuen biżanleria erabat alfabetatuati, ordurako ahozkotasuna iraganeko kontua zen seinale.

Bestalde, orainarteko paragrafootan eman ditudanak susmo eta senak gidatutako oldozketak baino ez dira; aurre hipotesiok baliagarri izan dakizkiguke ahozkotasunaren eta idazizkotasunaren kontzeptuei hauspo handiagoa emateko, agian Ongek ematen duen analisiari jarraitız: Orality and Literacy liburu klasikoan. (Patxi Salaberrik ere Ong darabil Axulatren gaineko bere tesian). Gainera Ong ezinbestekoa zaigu garai hauetako Euskal literaturari dagokionez, zeren Ongek bere tesian Petrus Ramusen edo Pierre de la Raméeren dralekiika aztertu zuelarik bi azterbide atera baikenitzake: alde batetik Dialektika "egia bilatzeko" mekanismoa da. Platonek egiten duen Sokrateren irakurketan behintzat, eta horretara, ahozkotasunarekin loturik dago (dotrina katolikoak dauden bezalaxe). Baina bestetik Ramusengandik abiatuko da XVIIl mendean suertatu zen ikasketen gaineko ikuskeran ("zientzietakoa naiz" vs. "letretakoa naiz" esapidearekin gaurdaino inmortalizaizen dutena batzuk batzuk). Dialektikak Topika gisa ulerturik argumentuen bilaketaz eta ebaluatzeaz ziharduen, gero Logikak bere gain hartuko zuen eginkizuna: diziplinen banaketa beraz honetara lotzen da: zientzia edo "egia" alde batetik, eta humanitateak edo "forma" bestetik. Bide honi eutsirik, joan gaitezke aztertzera ze alde zegoen Larramendik bultzatutako erreformaren eta RSBAPek bultzatutakoaren artean.

6 "Patriarkalismoa aitaren botera da, hau da, sistema familiar-soziala, ideologikoa eta politikoa zeinetan gizonek erabakizzen duten emakumeek zein eginkizun bete dezaketeñ eta zein ez - dela indarraren bidez, presio zuzenaz, erritualen bidez, tradizioaz, legeaz eta hizkuntzaz, ohituren bitartez, etiketaren bidez. heziketaz nahiz lan banaketaz - eta zeinetan emakumea gizonaren pean dagoen leku guztietan. Ez du nahitaez esan nahi inongo emakumerik botererik ez daukanik, edota kultura jakin batean emakumeek ezin ditzaketenik izan nolabaiteko botere batzuk. Esaterako. Crow tribu matrilinealean, emakumeek maila handiko eginkizun ohorezkoak betetzen dituzte zeremonia eta jaialdietan, baina hilekoarekin daudenean ezin dute inorekin harteman sozialik izan. eta objektu sakratu bilakatzen dira. Emakumeek eta gizonek fenomeno kultural jakin bat konpanizen dutenean oso gauza diferenteak esan nahi ditu genero bakoitzarentzat. Gizonek beloak daramaizatenean adibidez Ipar Afrikako Tuaregen moduan- urruntasun horrek pertsona horren estatusa eta boterea. ateagotzeko balio du, baina nekez esan genezake halakorik purdah jokabide kodepean bizi diren emakumeen gainean. Azken buruan banaketa. lerroa markatzen da beti, eta kultura guzti-guztietan markatzen da. modu diferenteetara bada ere.

"Era berean, patriarkalismoak ez du esan nahi aitaren boterea zuzenean semearengana pasatzea, nahiz eta botere-erlazio hori garai batean ez zen zalantzan jartzen. esate baterako feudalismoan edo familia victoriarrean. Alexander Mitscherlich psikoanalista alemanak arrastoa jarraitu dio aitaseme erlazio horren gainbeherari, industrializazioaren presioetan, masa produkzioan eta lan espezializazioan barrena: "lana" etxetik kanpora inten bezala eta gizartea konplexuago eta zatikatuago egin ahala, aita familiarengandik urrun dagoen figura bihurtu zen, hau da, garai batean zeukan aginte praktikoaren "mamia" galdu zuen. Hala ere, Mitscherlichek dioenez. "gure gizartearen egitura patriarkala oso lotuta dago pentsaera magikoari. Honako uste hau du oinarri: aita-seme, Jainko- 
gizaki, arautzaile-arautuaren artean dagoen botere harremana (ahalguztiduna (.. vindua) antolamendu sozialaren printzipio naturala dela". Ahalguztidun-ezindu harreman hori batez ere gizonen eta emakumeen artean gertatzen da, eta gure hezkunizak, antolamendu sozialak eta "pentsamendu magikoak" oraindik daramate irudi paternalista horren aztama." (Adrienne Rich. Of Woman Born. liburu klasikotik Ana I, Moralesek itzuli eta moldatua).

7 Oso esanguratsua da Anne Loken martirioa; Anne Loken martirioaren berri seguntik ez zuen Erregeak berak ere izan. errepresio mekanismoak bere bideak baitzituen, eta Erregearen jakinera maila goreneko erreformazaleen kasuak baino ez bairziren helduko. Anne Lokek ingelesezko lehen hamalaurkunak eratu zituen, Calvinen scrmoien itzulpenekin batera; hamalaurkunak edo sonetoak liburua 1560 an inprimatu ostean idatzi ziren atzealdeko orrietan (Jane Donawerthek eta Linda Dovek eginike transkripzioa in "University of Maryland. Course Packet \#10. Course name: English 719. Rhetoric and Early Modern Women 's Writing. Instructor: Jane Donawent." BelJean Printing. Beltsvilee MD, 1999): Sermons of John Cal-1vin, vpon the Songet that Ezechias made af-/ter he had bene sicke, and / afflicted by the hand of / God, conteyned in the 38. Chapifter of Esay. Translated out of Frenche/ into Englishe. 11560.

8 De Guise eta Navarre etxeak elkarren etsai izango ziren Europako mendebaldeko gorte askotan. Elizabethen ahizpa-erdia eta arerioa. Eskoziarren Mary erregina alegia, De Guise etxekoa zen. Labriteko Joanak bere buruaren justifikazioa den gutun liluragarri bat idatzi zion Elizabethi, eta hantxe diotsoz gauzak bion amen adiskidantzari eutsita: Memoires et poesies de Jeanne d'Albret publies par le Burun de Ruble. Paris 1893., edota: Historie de nostre temps contenant un receull des choses memorables passees et publiees pour le faict de la religion ef stat de la France despuis l'edict de paciffication du 2.3 jour de mars. jusqu'au present. 1570. Tamalez gutun hori ez dago oraindik euskeratuta, eta benetan mereziko luke, bai ikuspegi feminista batetik (adibidez, garaiko emakume idazleen artean lehen pertsonako izenordearen erabilera ez ohikoagatik), eta bai euskal literaturaren eskubide osoko iestua delako, edo behintzat eskubide hori eztabaidatzen hasi ahal izateko beste leku batzuetan egiten denaren argitan. Cf. Mary Eskoziarren erreginak frantsesez idatzitako sonetoak nola ageri ohi diren Ingelesezko poesia antologictan.

9 Humen Nafarroako Margaritaren bizitzari buruzko azalpen bat eman gogo dut, beharrezko uste ditudanak bakarrik. Oso nortasun konplexukoa zen bera, hamaseigarren mendeko Europako politikan pertsonalitaterik handienetakotzat jo izan da sarritan. Garaiko letren inunduan ederto ezaguna zen, poesiarako eta literaturarako zituen trebeziengatik. Gaur egun, ia-ia bakarrik aipatu ohi da Heprameroiagatik (zein, euskaldunon lotsarako, ez baitago euskeratuta). Gehienetan Mirraila aipatu ere ez da egiten.

Bere ama Savoyko Louise zen, eta hark irakatsi zion bere nebagazko deboziorainoko isuria: noraino eta, ume denboran, amak euren buruet "hirutasun santua" esateraino. Neba Frantziako errege izango zen. Frantzisko lehena - Iztuetari sinestekotan. Irundar batek atxilotu zuena Paviako gudan-zeinarengan Margaritak eragin handia izango ztien Frantziako tronura heldutakoan.

Oraindik Angulemako Margarita zenaren lehen senarra, d'Alençon, ez zen itzal handiegikoa gizartean, baina hura hiltzean, Margarita Normandiaren jabe egin zen: beraz, Margarita Angulema etil Alentzonekoa ordurako.

Bere bigarren senarra Henri Albretekoa Labritekoa edo Lebrettekva izan zen ("erbiño"). Henrik Goi Nafarroatik alde egin behar izan zuen arrapalada batean, bere ama Catherina Foixkoarekin batera, espainolek. Erresuma inbadicu zutenean. Baina beti iriczi izan zion bere buruari Nafarroako errege (eta susmoa daukat hizkuntzaz euskalduna zela, bere ondorengoak ez bezalia, gero aipatuko dudan aztama bategatik): kontua da ze gortesau bilakatu ez ziren handikienetako bat izan zela, bere bizitza osoa eman zuen Erresuma berreskuratu nahian. familiak. Frantziako gizarteko katenbegietan gora egitea bainoago. Enperadoreak, Karlos bosgamenak. Paviako gudan atrapatu 
zuen atxilo, Frantziako erregearekin batera: baina Frantziskok ez bezala, ihes egitea lortu zuen, ose era "gaskoi" batean: izarez osaturiko eskailera batetik jaitsiaz. Horren ondorioz, alde batetik. Henri gerrako heroitzat hartu zuten Frantzesek, baina, bestalde Parisen atzerritarra zen, eta Frantsesek ez: zuten ulertzen zergatik erabiltzen zuen errege bati zor zitzaion ponpa eta parizta: aniza bere gorteak Parisen zuen gastua izugarria zen, eta agian hortik hedatuko zen gero Frantziar literaturan ageri den gaskoiaren irudia. Irudi hori honakoan azter daiteke: Poisson. Raymonden "Le poete basque" antzezlana in Les oeuvres de mr Poisson. Divisées en deux tomes. Seconde edition, conigée \& augmentee ... A Paris. Chez Thomas Guillain, 1687 (Bidenabar, pare bat esaldi ageri dira hor euskeraz, eta horien gainean ez dut lan flologikorik ezagutzen).

Paviako gertaren ondorioz, Carlos V.ak urtebete izan zuen atxilo François fa. Frantziako erregea askatzeko diplomazia lanetan Marganita ibili zen. Erregea askatzeko eskakizunen antean, erregearen seme biak trukean han geratu beharraz gain, Nafarroako auzia erabaki zen: Madrileko itunean (1525) Frantziak Nafarroaren gaineko eskubideei uko egin behar izan zien, edo bestela esanda, Françoisek ez zion Henriri lagunduko Nafarroa berreskuratzen. Guzti honetaz. Henrik ez zuen ezer jakin urte askoan - bestela Henrik Carlosekin bat egin zezakeen Françoisen kontra, noski, eta horrek espainolak jarriko ziuen Boderleren ateetan-, eta Margarita bera ere ezjakina zen kontu horretaz, edo halan ziurtatu zuen berak behin eta berriro geroagogarrenean. Nafarroa betirako zen galdua 1525eko Madrileko itunean, eta Labritarrak ezjakinean omen zeuden horretaz. Henrik. urteak igarota. ez zion inoiz sinetsiko bere emazteari parte hartze guzti horretaz. ezer jakin ez ei izana, eta bikotearen hartu emana gaiztotuz joan zen aurrerantzean. Margaritaren lekua oso zaila izango zen hortik aurrera: alde batetik hezia zen bere nebaren alde egiteko, eta hala, bere nebari obeditzeagatik, ezkondu zen Henrirekin, baina, bestalde, bere senarrak eragiten zion bere nebarengan indar egiteko Nafarroaren arazoan.

Margaritaren bideak eraginbakoak zirela ohartu ondoren, Henri fahitrra bere lurraldeetara gorde zen. eta ordutik aurrera bizitza osoa emango zuen Valoisko koroaren kontra azpitik jokatzen. Honek aukera bi ekarriko zizkion Margaritati: edo bere senarraren atzetik joan eta gortea utzi behar zuen (garai horretan gontea ibiltaria zen, baina beti ere Bordeletik iparraldean, hots, Henriren lurraldeetatik kanpo), edo senarra utzi eta nebari jarraitu. Pentsa ezazue "heziera oneko" etxandre batentzat zer zen hori. Bestalde, nahi baino gehiagotan zegoen bere senarraren azpijokoen jakitun, konplizitateagatik epaitua izateko arriskuarekin, eta bere senarrak Frantziako gortean zuen izan txarra ere jasan beharko zuen. Senarrarekin zegoenean, nebak traizioaren sunda hartzen zion, eta presioa ezarri. Nebarekin zegoenean, senarak abandonatua zela esaten zion. Esan bezala, senar-emaztekikoek hondoa jo zuten.

Margaritaren bizitzak ispilaizen du garai horretako goi mailako emakumeen ezbaia: euren aiten etxaldea handitzeko trukaketa objektuak ziren, eta, hala ere, senarren laguntzaile zirelarik, ezkondu berri ziren exxearen onura eta onerakoen bilatzeari buru belarri ekin behar izaten zioten. Margarita bizi zen etxe biak elkarren arerio zirenez, ez zuen arreba-alaba ona eta. aldi berean, emazte ona izaterik.

Margaritaren Iehen umea emakumezkoa izan zen, Joana (Jehane) Labritekoa — guk aitoru eta ikertu baino garrantzia handiagoa izango zuena euskal literaturan - eta gero galdutako beste bah. Bikotearentzako Joana eztabaidagai eta liskarren iturburu ere izango zen: alde batetik lege Salikoagatik ez zen Henrik nahiko zukeen primua, eta bestalde, erregearen aginduz, Joana aitaren lurraldeetatik kanpo hezia zen, amaren lurraldeetan, Normandian hain zuzen. Gogoratu euskal legeen jardunak agintariari eskatzen diola batzarretan egotea eta Herriaren lege eta ohiturak ondo ezagutzea.

Erlijio arloan eta intelektualean, Margaritak lehen mugimendu erreformista babestu zuen. Bere nebak hasieran ontzat hartu zuen, baina gero, erreformismoak egitura hierarkikoen kontra egotearekin batera bere baitan daraman demokraziarako haziak atzez eraginda edo, gogor jazarri zitzaion: berez, gainera, Françoisek ez zuen Erromatiko urrunagoko aldentzerik behar, zeren Erromak, Ingalaterran gertatutakoa Frantzian ere gerta zedin beldurrez. emanak baitzizkion libertate franko Galikanismoaren bitartez. Aitzitik. Henrik berc lurruldeetan zuen erlijio politika itzuri bikoa edo anbiguoa zen: tegez edo teorian, erreformisten kontra zegoen, berez edo praktikan, erlijio kontuetan ez zuen bere burua nahasi nahi. Jarrera honek lur neutrala sortu zuen, bere alabaren garaian adie- 
razpen askatasunera eramango zuena. Artean baina. Margaritak nozitu behar izango zuen bere sentikortasun erlijiosoak eta intelektualak ezin gauzatzea bide politikoak uratu gabe egoteagatik. Kalbinismoak. presio handia jartzen zuen handikiengan - ustez buruen atzetik etorriko zela herri xehea- atera zitezen armairutik eta terakutsi munduari zer pentsatzen zuten benetan. Margarita ez zegoen horren egoera. orekatsuan non senarrari eta nebari, bi-bioi, aurre egin ahal izan ziezaiekeen. baina guztiarekin ere, bestera pentsatzen zuen giro disidentea bultzatu eta indarzea fontu zuen.

Margaritaren alabaren idazkien azterketan oinarriturik, eta Onthezko Akademiaren curriculumari buruzko araudia kontuan harturik (Roelker 1968), Maroten Salmoen itzulpena aipatuko nuke garai tartako pentsalari askeen ikur gisa. Oraindik ez dakit nola josi, baina uste dus garai hartako ingurune intelektualerako gilizarri suertau behar duela salmoen inguruko tadibidez Jean Ezpondaren) meditazio lanek edota lan aszetikoek. Tamalgarria da Oñatiko Unibertsitatearen gainean egindako lanek erakusten duten beldur postkoloniala (vasco edo nazionalista dei ez ditza(en): Nire ustez hiru dira. Euskalerrian kontutan hartu beharreko gauzak garaiko mugimendu kulturala ulertzeko: Jesuiten sorrera (eta euren crlazioa Frantziskotartekin eta Agustindarrekin hezkunzari dagokionez), Orthezeko Akademianen somera eta Oñatiko Unibertsitatearen sorrera, azken biok elkari loturik zeuden bandockin erlazionaturik; zein zen hiru institurio horietan eskatzen ziren betebehar akademikoak eta zein zen ikasle sartu berriei sartu aurretik suposatzen zitzaiena. (Eskuragarriago gurako nuke erreferentzia hauxe: Coudirolle, Joseph. Elude sur l'Academie d'Orthez, fin du XVle ef commencemen du XVIle siecle.. J. Goude-DumesniL. Orthez: 1885$).$

Lehen agindu dut azalduko nuela zertatik atera diodan susmoa Henri zaharra, Margeriteren senarra eta Joanaren aita. euskalduna zela; oso oinarri ahula da, baina ikerketarako abiapuntua izan daiteke hala ere, eta amazola hauxe da: Karlos Vak Henrigaz azpiko harremanetan espioitzan aritzeko Martin Ezkura arabara ("Descurra" garaiko testuetan) jzendatu zuen. Nik uste dut Karlosek bazekiela zer egiten zuen euskaldun bat beste euskaldun batekin lotzean. Berriz, bere ilobak, Henri IV.ak, ez zekien euskeraz, eta hori demostratuta dago, behin, bere amaren izenean Behe Nafarroako matxinada bat zapaltzera joan zenean, hangoekin berba egiteko itzultzailea behar izan zuela dioelako testuak. Nik uste dut François Frantziako erregeak ere bazekiela zer egiten zuen Henrizahamaren alaba, Joana. Nomandian. amaren hurraldeetan, eta ez aitarenetan, heztea agindu zuenean, hizkuntzari eta lege-ohiturei dagokiencz. Beste iker-bide interesgarri bat izan daiteke aztertzea zelan aldatu zuen herriaz zuen ikuskera Behe-Nafarroako foruak agindukeran senarra bere buruaren gainetik jarri zuenetik Akademiako araudiak eragin zituen arte.

10 Erretorika. Lehen liburua, bigaren atala, 4. 5 cta 6 paragrafoetan; $1356 a-1356$ b bitartean. Noski, ethos eta pathos gaut egungo narratologian ere landu izan dira. adibidez. Seymour Chatmanek kontzeptu hauek bereizi ziluen:

Benetako egilea. egile inplizicua edo suposatua eta narratzailea

Benetako irakurlea, irakurle suposatua eta narraziosk nori diotson edo hartzailea (narratec-a)

Chatman (1980). Story and Discourse. Apud David H. Richter (arg.). Narrone/Theory. 1996: New York. Longman Publishers USA.

1! Michael J. Reddyk azaldu zuen zelan komunikazio prozesua ulenzeko erabiltzen duguna kanalaren metafora den; hots, igorlea, kodea cdo mezuat. eta hartzailea kontzeptuak komunikazioa kanala balio bezala metaforizatzetik datoz. Metaforek gentaera baten gainean argi berria isurtzen dute. baina gertacra horren beste alderdi asko czkutatu ene egiten digute. Esan nahi baita askotan ahaztu egiten zaigula komunikazio prozesua ez dela igorle bat. mezua eta hartzailea horiek kanalaren metaforaren alderdiak baino ez direla. komunikazio prozesua askoz ere gauza konplexuagoa dela eta segurutik informazioaren "trukaketarena" alderdirik sinpleenetakoa dela prozesu horretan. Edo bestela esan, ahaztu egiten zaigu metafora bat erabiltzen ari garela, eta metafora deskribatzen dihardugu. Konunikazio prozesurako erabili ohi den kanalaren metafora hori folk teoria edo herri ikuskera da (eta ziutrenik komunikazioaz mintzatzeko erahil dezakegun bide bakarra ere bai). Ikus 
Michacl J. Reddy "The conduit metaphor: A, case of frame conflict in our language about language" adibidez bilduma, honetan: Ontony. Andrew (arg.) Metaphor and Thoughr. 2.ed. Cambridge University Press, 1993. Espainolera itzulita dagoen Lakoff eta Johnsonen Metaphors We Live By ( Metáforas de la vida catidiana) horretan ere zeharka azalduta dago.

\section{Ikus PereIman eta Olbrecths-Tyteca horretaz.}

13 Gogoan izan Augustimen egin beharra. behin kristautasuna boterera heldu eta gero. kristautasunerako zein iturri izan litekeen baliagarri epaitzea izan zela, bere Doctrina Christianan ageri den bezala. Bestalde honek bere garrantzia ere badu zeren Erreformistek esango bailukete San Augustin izan zela gauzak artez ikusi zituen azken katolikoa, hortik aurrerantzean katolikotasunak bereganatu baitzituen lekuan lekuko sineste paganoak. Hau da, emeformistek euren gain hartuko zuten eginkizuna kristautasuna paganismotik garbitzea zen (pietatea zer zen eta superstizioa zer zen bereiztea, alegia), hots. kristautasuna baino lehenagoko ohituretatik begiratzea; horrelaxe ulertu behar da Joana Labritekok esaten zuen hura Euskalerriko eliza guztiak kandeletark libraru zituela, eta marko hori da lan honen hasierako paragrafoetan ezarzen saiatu naizena ahozkotasuna eta idatzizkotasuna kontrajarri ditudanean iestutik haralage espamuetarako.

14 Gogoratu Cicerok sumikstimo gehiegizko pietate bezala definitzen zuela, eta horren harian crmeformisten gainean lehenago aipatu dudana.

Bestalde, bemen eman ditudanak bidea labutzeko izan dira, baina berez honek erretorikaren ikerketa sakonagora eramango gintuzke, Augustinek berak ematen baitio pietateari legea desanbiguatzeko ahalmena, hots. aequalitas delakoaren eginbeharra: "Beraz, otzan bihurtu behar gara errukiaren bidez. Eskritura Sakraiuari kontra egin ez diezaiogun, dela ulertzen cz, dugunean eta gure bizioren bati eraso diola iruditzen zaigunean, dela ulertzen ez dugunean eta bera baino jakintsuagoak eta arauak emateko egokiagoak garela iruditzen zaigunean. Aitzitik, hobe genuke pentsatu etä sinestea idatzita dagoena hobea eta egiagoa dela guk geurenez pentsa genezakeen edozein gauza baino, baita idatzita dagoen hori iluna denean ere". Bigarren liburua, VII atala, 9. Paragrafoa (ikus bibliografra đarabildan bertsiorakot. Argi đago Etxepareren lana ulertzeko honekin batera aztertu behai dela.

15 Berdintasuna bi eratara erabili dut: Aequalitas esateko (orain) eta equitas esateko (gorago). Hauzutasuna erabili dut pasane honetan, baina normalean equitas esateko crabiliko dudan berba "berdintasuna" izango da. Kontuan har beza irakurieak termino teknikoa dela, hots, legea instantzia partikularetara egokiizea.

16 Augustinen lehen liburukia laburbilduko dut hurren. ikus dezaguñ zelan erateen duen alde hermeneutiko jokabiderako arauetatik aterata. Nire iritzirako, lehen liburu honetan hermencutagaiaren gogo egocra prestatzen ari da.

Alde batetik, bere lehen liburuan Eskrituren irodoketa eta euren irakaspena bereiziko ditu: ikerkuniza eta pedagogia alegia, edo bestela jarrita, hermeneutika eta heuristika (1, 1-1), Gero gauza eta zeinua bereiziko ditu: esaten du gauzak zeinuen bitartez ulertzen ditugula, hau da, erreferente bakarreko berbak "gauzak" dira (egurra, harria, aberea), eta horien erabilera metaforikoa "zeinuak" (1. 11-2). Bigarren liburukiaren hasieran berriro jardungo du honetaz, eta badirudi "gauzak" erreferente kontestuala duen bitartean, "zeinuak" simulazioren bat suposatzen duela (simulazioa teknikoki hartuta).

Bigarren maila batean hasiko da bereizten desiragarri izan daitezkeenen artean eta bi multzo egiten: erabilzzekoak eta gozazzekoak. Erabiltzeko gauzak gozatzeko gauzak lortzeko bide dira, eta gozatzekoak halakoak dira berez: Aila. Semea eta Gogo Saindua; batasuna, berdintasuna eta bien bateratasuna (1, II-V). Alabaina, dio Augustinek (I, XXIII-22), erabiltzeko den guzti cz da maita- 
garria. Gauza maitagariak lau motatakeak izan daitezke - eta berriz goaz Ciceroren wequalifasera-: gure gainetikoak, gu geu eratzen gaituztenak, gune berdinak direnak, eta gure azpikoak. Laurotatik merezi dutenak lehendabizikoak dira. Bi mailok XXXVI, 40-41 paragrafoetan lotuko ditu, maila morala eta maila intelektuala (berez Jotuta daudenak Jainkoaren definizio intelektualarekin, Jakituria hutsa den aldetik) eta esango du zelan Eskriturak ulertzearekin maitasunaren arau bikoiza (Jaikoari eta lagun hurkoari) eraiki behar duen hemencutagaiak.

Zelanbait esan, irakurtzeko jakin-mina izan behai da, eti idazkiar autoritatea aitortu behar zaio (fedea); hori alde interpretatiboari dagokionez. Eta behin zerbait idoroz gero, aurkitutakoa irakasteko karitatea. beharko da. Hori guztia Jainkoarekiko maitasunak, hots. gozamenerako gure gainetiko gauzari arimak dion desirak gidatuko du. Augustinek esango du (XXXVII-XL) interpretazio erratu bat erratua dela jakin daitekeela aurreragoko tesiuarekin bat ez baldin badator; homen aurean jokabide zuzena lizateke norberiren interpretazioa bertan behera uztea. Lehenagoko interpretazio okerrari eutsiz gero, horrek fedea ahulduko dio hermeneutari (hots, hermeneutak ez dielako Eskriturei behar besteko autoritaterik aitortuko). Baina maite eta sinesten duenak esperantza izan lezake mate duenera inoiz heltzekoa. "Horrela, jakituria eta profezia oro hiru gauzaren atzetik dabilıa ekinean, eta hauek dira: fedea, esperantza eta karitatea". Eta aurrerago: "Beraz, batek 'bihotz garbiaz, kontzientzia onaz eta fede zintzoaz' (Cor. 1, 13 13.) ezagutzen duenean Jainkoaren aginduen xedea karitatea dela, eta Eskritura Sakratuez ulertzen duen guztiá hiru horiekin erlazioan jarzen duenean. orduan hel diezaieke ziurtasunez liburu horiei"s.

17 "image-schema" apud Turner 1996. Ikus erreferentia bibliografikoak.

18 Danteren Komedia Jainkotiarreko azken stanzarekiko antzekotasuna ere nabarmena da, baina horrek ez garamatza inora, fan honetan behintzat, askoz jota inefabilitatea leku arras komuna cila esatera.

19 Augustinek oroimena etoriaren gainetik jartzen du esplizituki.

20 Orduko hizkunt/alari ortodoxoek bakarrik begiratzen zioten joskerari, ela gustu txarrekoa ematen zuen esanguraz jarduteak, baldin eta ez bazen ikuskera positibista edo formaletik. Areago, metafora bezalako gauza komunak amandre ipuintzat harıen ziren "zientziaren" jzenean, eta zientzia egiteko fisikaren erretoritid srabili beharra zegoen. Batzuk-batzuek metaforaren existentzia ukatu eta guzsi egin zuten, edo baldin bazen metaiorarik ezinczkoa zela horretaz zientifikoki hitz egitea esaten zuten.

Bemardezek badu liburu zoragamro argi bat garaiko hizkunczalaritzaren zoroztasun eta mehartasun honetaz. Bere helburua oso bestelakoa da, hain zuzen zientziari (paradigma estandarrari) zurruntasuna biguntzea, eguraldiaz diharduten zientzia fisikoen malgutasuna aplika dakion testu mailako ikerketari (Kaosaren teoria), probabilitatearen aldagaia igargarritasunari edo prediktibilitateari erantsiz. Bernardezen liburu horrek ispilatzen ditu artezen sintaxi arazoak ikertu nahi ez izan arren hizkuntzaz (modu zientifikoan) eta baita literaturaz ere genbiltzanon arazoak. (Bernardez Metodologia y Epistemología del Textr. Cátedra. Madrid: 1993). Penaz izan dute hizkuntzalari sorizaile edo generatiboek gure unibertsitatetara sarzeko, baina behin sartuta aurrekoak bezala egon dira begi mozzaz lagun hurkoaren lana gutxiesten, batzuetan terminologia diferentean babes harturik, eta askotan euren formazioko alde garrantzitsucnetako bat ukatzen: horrek ito egin ditzake hainbat ikerbide etal egitasmo.

Pentsatu behar duguna zera da, segurutik Newtonek aurnera egin zuela ez bere teoria Ptolomeorena baino hobea zelako (hasieran ez behinizat), jendea zeruari begiratzeaz aspertu egin zelako baino. Momentu honetan Euskal Herriak ditu inoizko hizkuntzalari eta ikerlari bikainenak, gehienak atzerrian ibiliak gutxi asko. joera eta isuri ikaragami aberatsekoak: (harrigarriro, soziolin- 
guistika eta euskera-lehen hizkuntzaren jabekuntza izan daitezke gutxien landu direnetakoak). Batzuen eta bitzuen txokokeria eta sektarismoak gainđituz gero, eta erakundeak inbertitzera ausartzen badira kanpokoen baimena edo kanpotiko ereduren baten zain egon barik, uste dut munduari eman ahal izango diogula aurrerapenik eta ekarririk asko: bakarrik jarraitu behar diogu Kanten esapideari: Sapere aude.

${ }^{21}$ Lakoff eta Johnson, ikus bibliografia. Bada gaztelerara itzulpen bat ere, bost bat urte beranduago atera zena Cátedra argitaletxean. Baina nire ustez liburu landuagoz eta mamitsuagoa da Lakoff eta Turnerrena 1989 batez ere ikerketa. literariorako (ikus bibliografian).

22 Integratze Kontzeptualaren Teoria edo Bateraketa gogo-espazioaren Teoria (Fauconnier \& Turner 1994 lik aurrera) baino aurreko paradigma teorikoan (cf. adibidez Lakoff 1993) metafora honelaxe definitzen zen: sorburu batetik ateratako egitura eta topologiak jomuga batera proiektatzea. Proiekzio hori esparru diferenteen artean gertatu behar zen, espartu berean gertatuz gero metafora barik metonimia baikenuke. Hizki larriaz idazien diren adierazpideak $X=Y$ tankerakoak dira, non lehen elementuak (xedeak) bigarrenaren (sorburuaren) egitura eta topologiak bereganatzen dituen. Adierazpideok ez dira exhaustiboak, baina ahalik eta hizkuntza naturaleko adierazpide metaforiko gehien azaldu behar dituzte. Oinarrikoago adierazpide bat aurkituz gero, horixe genuke oinarriko metafora kontzeptuala.

13 Osu aberasgarria litzateke Bonapartek agindutako itzulpen biblikoetan honako adierazpideak aztertyea: mutuak askatu, herrenak zuzendu, itsuak argitu...eta abar. Zein dira esamolde horien azpian leudekeen oinarriko metaforak?

24 Sweetserren (1990) liburuaren ekarririk garrantzizkoena hauxe litzateke: aurkitzea, baita etimologian bertan ere motibazio metaforiko bat atdaketa semantikorako. polisemiarako bezain bestean: hots, eboluzio semantikoa ez da arbitrarioa. Mundu fisikoarekiko esperientziatikoak proiektatuz. lortzen ditugu kontzeptu abstraktuak, ela bigarren metaforizatze batez hizkuntza-egitateak. Ikusi, bestela, "evident"en etimologia Knowing is SHinci (JAkitra IKuStha DA) metaforaren araura. Cf. "Begiaz eta egiaz" esamoldea. Euskeraz, hala ere, "aditu"ren polisemia korapilotsuagoa da: entzun. usaindu, ulertu, ikusi. Beste kasu bat Iztuetak nola darabilen "ulertu" aditza izan daiteke, Euskera esparru indoeuroparrean erabat sartzen ez den seinale, baina guztiarekin, aldaketa semantikoa eta polisemia arbitrarioa ez dena. Oharmen aditzen gainean ikus Iraide Ibarretxeren tesia: IbarretxeAntuñano, Iraide. 1999a. Polysemy and Metaphor in Perception Verbs: A Cross-linguistic Study. PhD Thesis. University of Edinburgh.

25 Honen subiimazioa "Neu naiz bidea eta bizitza" esaldian daukngu, zeinetan Jesusek modua eta helburua dela baieztatzen duen; berez integrazio kontzeptuala da. Ikus Tumer 1996.

26 Honek gramatikan bertan ere badauka garrantzia. Ikus,adibidez, ingelesak berezkoa đuen "bide"dun egituraren azterketarako: Goldbergen Construction Grammar. Chicago: 1996. eta horren ikerketa historikorako Michael Israelen "The Way Constructions Grow." In: Adele Goldberg (arg.) Conceprual Structure. Discourse and Larguage. CSLI. Stanford: 1996. Hor azterzen diren egiturak hurrengoaren tankerakoak dirat: "hordirik bere bidec narrastu zuen gelatik kanpora"(?).

27 Noski, euskeraren kasuan "bide" eremua zailtasunik ere badu, "bide" "antza denez"-ren sinonimoa ere kontsideratu beharko baikenuke. Halaber, aipatu dudan "bide"-ren beste esparru semantiko 
hori ere, 'modu' edo 'kers' esanahiarena alegia, bamuan hartu beharko zen. Ahalegina ez datza hiru ulermoduak har zilzakeen koncepu zabal askoa aurkitzean, baizik eta hrurok elkarrekin izan dezaketen bide metaforikoaren nondik. norakoak zehaztean. hau da, aurkitu behar da zein lizatekeen esperientzia fisikoarekin lotua dagoena (adibidez, "bide biren arfean" cf. LAH. IS A JoURNF., BUTT/A IMAM IA. eta bidaia hotretan erabakiak hartu behar dira, v.g. "bidegurutzean" eta abar.). A.ndres Urrutiaren lanak ("Olerkaria lege autuelan: Etxepareren Lingaae Uascomam Primitiat ikusmira juridikopean" In: Ensciukarrean. 121 19961:36-55) alderdi lexikalari eusten dio: hala cre. legearen lexikoa hiz ickinikoez osaturih dagoen heinean aztertzea oso bestelakoa da hemen araitzen dendatzen naizen bidetik.

Honez aparte, argi dago Exxeparek, Margaritak bezala redo Garci-Lassok bere bosgarren kantuan) zerabilten hizkuntzaren polisemiren barruan erabat aurreikusia zutela legearen ubera.

28 Ex dut honetan lar luzatu gura, baina aipamentxo bat egin beharrekoa da. Antzekotasuna diogunean ez gabilzza estrukturalista zaharak ematen zizkiguten sema berrantolaketaren gainean, antzekotasun hau ez baita objekibista: hauxe da konua: kutura batek "lehoia" modu batera dauka kontzeptualizaturik, adibidez errege bezala (berez legora katu handi bat da. ez errege, zeren gobernuaren kontua, eta are monarkiaren snakronismoa, gizakiona baita). Legoiaren konteptualizazio kultural horrekin bilatuko zaio antzekotasuna Akiferi. Animalien kontzeptualizazioan bere biziko garrantzia du "Izaeraren Katea Nagusiaren Metafora" credu kulturalak (Great Chain of Being Metaphor, Lakoff \& Tumer 1989). Excdu horren arabera, izaeraten itxuran oinarriturik izaki horri gizakien jokaera batzuk leporatzen zaizkio: beraz, itxura edo forma sorburua da eta jokaera, berriz, xedea. Honekin loturik, esan genezake euskal zoologian legoiaren funtzio batzuk hartzak betetzen dituela.

29 Santa Barbaran 200 leko uztailean egindako Linguistika Kognitiboko kongresuan Lakoffek metafora bi neuronen arteko lotura bezala definitu du. Horrekin agertu duen jarrerak konekxionismoarekin bat egin du; oso jarrera crradikala (ez ona ez ixarra. baina bai bulartsua). Zuzen ala oker dagoen. neurobiologiak esango digu (eta badirudi hein batean halan dioskula), baina bada lotura bat Gradyren aurkikuntzekin; Gradyk bi esperientzia maila zeharo diferenteren arteko lotura aipatzen du, lotura horren nolakotasuna zelakoa den deskribatzen denean helduko gara Lakoffen planteamendua epartzeko tresneria izatera.

30 Konkretutik abstraktura esango lukete baizuek, baina niri irudizen zait "abstraktu" terminoak esangura labainegtak dituela. Hizkuntzalari knonitiboek erabilten dutenean "abutraktu" terminoa hauxe esan gura du; esperientzian zuzenean oinarritu bakoa

3 Berez. euskarak zorrotza eta zurruna berciziko liuzke. Gai honen ikerketa litzateke hizkuntzalari kognitiboen eginbeharra. Gainera ikerketa horrek elimologikoki bi terminoon artean egon litekeen (susmoa da) parekotasunaren zergatia eman beharko buke. Etimologian kekikogintza metaforak gidatzen duela argi ikus daiteke temino hauekin: moztu, mozkor, motil (eta mutildu), motz.

32 Hau oso gai korapilotsua da. saia nadin tkbur ematen. Bercz, kausa indar-dinamikaren arabera ulenzen dugu: zelambait esan. paradigma mekanizisia. non gorputz batek besto bat abian jartzen duen kontaktu fisikoaren bitatez, herri teoria da. edo bestela esan, txikitandik eta gure esperientzian oinarritutakoa. Beraz, hortik zera dakargu, mugimendu guztik kausatua izan behar duela. Berez mugizen diren izakiek arazoa sortzen dute azalpen orokor honetan, eta hortik dator arima edo animaren asmatzea. Motu propio edo berez mugitzen denak animatua edo arimaduna izan behar du. Eta arman nahia edo intentzioa leporatu ohi zaio (azken batez Jainko edo azken kausaren zati bat dira, eta abar). Hortaz arima berezko mugimenduaren, hots biziaren, eta intentzioaren printzipioa da. Honi itzulia eman ahal zaio eta esan berez mugitzen deouk intentriou duela. 
33 Horrelako Oinarriko Metafora kontzeptuala propisatzeko askoz ere datu gehiago beharko nituzke, datuok hizkuntzatik eta kulturatik ateratakoak liratekeclarik. Beraz. NAHA NOHAmuFA DA edo Lttt. IS A H. Hu ez dute maila epistemologiko bera, azken honen atzean ikerketa eta datu mulzo askoz ere handiagoa baitago. Beude neureak, hortaz. proposamen mailan eta besterenak maila enpirikoan.

34 Antzeko metonimia arsotitz honck erakusten du: "Behin Maria Elizara, eta bertan ipurdiaz aldarera". Ipurdia aldareari emateak daukan esangurak argitzen du atsotitza. "Izpazterreko Errefrauak." In: Bonapure Ondarekn Eskuzhribuak, Bizkiere. 1. liburukia. Bilbo, Deustuko Unibertsitatea. Euskal tkaskuntzen Institutua, 1992, orr. 177.

35 Hona hemen testuan familia erlazioei aipu egien dieten lexiko item batzuk (1548ko ediziotik atereak eta TACT programa erabiliz):

fraternyte (1); brother (22): brotherhede (1); brotherly (1); brotherlynesse (1);

syster $(18)$;

mother (22):

rather (33); pater (1); paternyte (3);

chylde (17): chyelde (2); doughter (6); doughters (1); doughterly (1): daughter (5): daughterly (!); spouse (11); husbande (12): husbandes (1): wy fe (13); mariyage (1): mamy (1): marryage (1): marryed (1); marye (1)

quene (3); kynge (6); kyng (1); lord (1); lorde (14); master (3); mastre (1): masiores (1);

36 Ohorea uletu beharko genuke arako merkatal iragarpen gisa edo hatteskundeetarako propaganda bezala: boto emaile edo crosieen kopuruak zerikusi żuzena zuten prestigioarekin. eta, luzarora, boterearekin; kontrakoa ere suertaken zen. menpekoak indartsuenengana jotzen zuten babes eske; luzaroan horrek diru sarrera ugarituko zuen. Zenbat eta lagun, lotura eta "ukondo" gehiago eduki lekuetan. hatan eta boteretsuago bilakatu (edota boteretsua zen seinale argiagoa izan). Izaera diadikoak esan gura du inguruneak ezagutzen duela norbanakoa: pertsona bati izena eta ezaguera inguruneak ematen dio. eta kokatuia dagoen familiaren araberakoa da. Adibidez, Bermeon galdetzeko "zu nor zara" beti galdetuko dizute "nongos zara" - baldin eta uste badute herrikoa zarela-, hau da, zein familiatakoa zaren ari dira galdeizen, cdo, horren ezean, zein herritakoa. Horregatik ezizenek abizen furtzioa betetzen dute Bermeon, czizena hurrengo belaunaldietara ere igaroko baita. Itzala edo omena (cf. nomen) baten familiari besteck ematen zioten izenari lotua zegoen. Beraz, botereak gora egingo zuen prestigioarekin batera, lekuetan izandako lotura eta ukondoekin batera, eta lagunen maila sozialarekin batera.

\section{Malina 1993: 79. Or}

38 Malina: 1993. Ikus bihliografia.

Malinaren analisiari nik alde kognitiboaren garapena baino ez nioke erantsiko, fots, Lit-s is A H.un, Ir/T/A ISURKM DA. Bilatu beharko genuke horrela geriatzen ez den kulturaren bat, eta. gainera, saiatu ateratzen zelan oinarritzen den gure esperientzian arako kontzeptualizazioa. Bestela ctabat koherentea eta batera dator hurbilketa kognitiboarekin: adibidez, objektu risikoak metaforizatzen dira ahalmen abstraktuei aipu egiteko, eta beste.

39 Euskeraz honen antzekoren bat erabiliko genuke "zeure egur (?finantziero)en bila zabiltza gero". Arazos euskarazkoarekin zera da., oso zaila dela zehaztea zein den iturria: gurutzerako egurrak. norbera sutan erretzeko egurrak, ała garrotea? Baina adibide hau honetara zetorren: zuk zeure hilobia oso sakon egin arren horrek sorburuan ez zaituela heriotzara hurbiltzen, metaforaren emaitzan jasotzen dugunaren kontrari. 
40 Mark Tumer and Gilles Fauconnier (1995) "Conceptual Integration and Formal Expression". URL: http:/philosophy.uoregon.edu/metaphor/turner.htm Eskuratua: 01/08/29.

41 "Les êtres humains ont une aptifude unique pour exécuter un genre très avancé d'intégration conceptuelle. Ce genre avancé est appetê, en anglais, "double-scope integration", et en français, de manière inexacte, "l'intégration bilatérale." Lintégration "double-scope" est, comme je propose. l'aptitude principale que nous utilisons pour innover. C'est la faculté mentale qui caractérise le cerveau humain. C"est la faculté qui sous-tend d'autres facultés mentales uniquement humaines."

Mark Turner. 2000. "L'imagination et le cerveau" conférence donnée au Collège de France, 11. place Marcelin-Berthelot, Paris 5e, le mardi 6 juin 2000 à 1 th 30 , dans la salle 2. URL: http://www.wam.umd.edu/ mtum/WWW/cdf.html. Eskuratua: 01/08/30.

42 Lehen Etxepare aztertu duguncan. deskubritu dugu borondatea bektore bezala ulerzen dela, leku batetik besterako norabidearekin. Etimologiak berak erakusten digu in-tentzioa norabaiteko joera edo isuria dela. Axularrek oso ondo zekien bezala. Atentzioa aurpegiari lotzen zaio, eta direkzionaltasun horretan norabide aldaketa erakusten du. Paradigma katolikoan "Amagana bihurtzeak" borondatearen erakusk gisa ulertien da, eta beraz, ordua anteko norabideaz damua. Paradigma erreformistan, ikusiko denez, borondate hori exabatu behar da, borondatea malgutu. (Cf. "Behor zaharrari orgabidean nekez da irakasien", zergatik?

43 Honen harian ulertu behar dugu "Aldats Dorrean" erromantzea, senarraren amaren ahotik entzun dezakegunez:

"...esan buvbanan lehenengotatik jaukid'

izango ebanan Aldats Dorrean partea" (...) (amaginarrebak)

"Haurtxo txikiak deust sabelear ostik"

Jaun zerukoak ahal dau semea sortuko" (emazteak)

nahi dan seme nahi dan alaba

Aldats Dorrean partea izango jona" (amaginarrebak)

Ohar bedi irakurlea, "jona" eta ez "dona". hots. umeak izango dun parte, baina ez heuk.

44 Oso esanguratsua da zenbatetan ageri diren Kantuen Kartatiko aipuak.

45 Azterketa oso eta agortzerainoko baterako ikus hobeto Turnerren tesia, batez ere bosgarren eta bigarren atalak. "progeneration as Cause" kontzeptua: Turner, Mark. Deoth is the Mother of Beauty. 1987.

46 Honen adibide asko eta asko tbon Sarasolak Contribucionn...en argitaratutako gutunekin dauz. kagu.

47 Bada Kantuen Kantari buruzko interpretazio bat Genesian galdutako paradisuaren berreskuratzea bezala, bekatu-bertute berberen bidez. Eva erakarri zuen iurreko har-sugearen ordez. Shulamitak Erregea maite du. Guldu zen ohorea berrezarzen da. Agian interpretazio hau azal eta zabal ibiliko zen garaian. Baina are zuzenago diosku San Augustinek: "Our malady arose through the corrupted spirit of a woman: from the incorrupted flesh of a woman proceeded our salvation". I, XIV. 
48 Gorgias.

49 Termino horiexek erabiltzen dira gaur egungo gaztelanian maitelagunak aipatzeko.Bilakaera semantiko horrek balizko polisemia batean izan lezake motibazioren bat, Sweetserren ildotik.

50 Urteak aurrera igarota, hauxe izango dugu holaks eztabaidetako argudio tipikoa. adibidez Susanna Parr-en Apology: Against the Elders 1659 (Graham et al. 1989).

51 Nafarroako erregewa ez zen absolutista, ohituren menpekoa baizik (Foruak edo Common Law). Beraz, indarren oreka zegoen parlamentuaren. hots, alde zibilaren, eta erregearen edo alde militarraren artean. Jakina denez, sistema honetan errege edo erreginak foruen zina egin behar zuen koroa hartu ahal izateko. Foruen kontra zihoan legeren bat emanez gero, herriko sindikoek esku hartuko zuten. Sindikoen zeregina herriaren usadioa gogoratzea zen, kolektibitatearen nolabaiteko "disko gogorra" ziren ahozko sistema hartan. Errege edo erreginaren boterea murrizteko modu berezia, hata ere, gerra kontuak nugatzea zen. Beren-beregi adierazita zegoen errege/erteginak ezin zuela ez gerrarik egin ez bakerik sinatu "herriko hamahiru zaharren" baimenik gabe.

52 Bestalde, interesgarria cre buda azterizea noiz hasten diren gizonezkoak fideltasuna eta ezkontza agintzen eta eskaintzen maitasun edo mesede sexualen truke, horrek aurreko egoera libreago bat begietaratzen baitu (Tere Irastortza "Oihenarten Poemagintza." In: Hegars: Literatur Aldizkaria. 7(Ahendua 1992): 17-33). Gainera gauzak ez ziren berdinak izango gizarieko maila guztietan, himenaren kontrola primuaren jabegoarckin baitago lotuta, hots, aitatasunarekin (amatasuna ezin da zalantzan jarni eta).

53 Bidenabar, ingelesezko itzulpenean bada jatorrizkoan ez dagoen esaldi bat:: "Eta inongo gizonek desira dezakeena haino gehiago eta hobearen jabe naiz" ("I have more and better ihan any man can desire" (Elizabethek apropos sartutako aldakia?)

54 Usie dut honek harreman zuzena izan dezakeela katolikotasunak filologia judutik. bereganatutako lzenaren inguruko hermeneutikarekin (adb. Hillelen arauak edo notankota, halaber Fray Luis de Leon, De los Nombres de Crisus.

55 Azterbide honek luzeegi joko luke artikulu honen helburuetarako, baina ezin utzi aipatu barih hemen egin daitezkeen inferentriak. Maitasun neoplatonikoa daukat gogoan, non aurpegia hain inportantea zen, eta horrek gaur egungo zentait esapiderekin ("aurre egin diezaiogun arazoari") daukan erlazioa. Neure analisiaren arabera aurpegia asmo edo intentzioaren korrelatiboa izango lizateke, hots, atentzioa (eta, cz dezagun ahaztu. "aurpegia arimaren ispilua" ei da):

"Hast thu turned thy face from me? No, for thyne eye so swete ded penetrate my harte, woundynge it almost to the deathe. and gevynge me remorse of my synnes".

56 Horregatik garrantzia handikoa da Rosslyn Frank eta Mikel Susperregiren lana. "Conflicting Indentities: Non-commensurate Reral Metaphors in Basque and European Image Schemata." URL: http://ibs.Jgu.ac.uk/sympo/page4.heml.

57 Oso interesgaria da aspaldi batean Lloydek polarizazioaren gainean emandako azalpena: gainera garai aurre-Aristoteliarrekin jarizen du harremanetan (cf. Aristoteleren oposaketen taula) 